Chapman University

Chapman University Digital Commons

War and Society (MA) Theses

Dissertations and Theses

Fall 1-2021

\title{
"After all, who takes care of the Red Cross's morale?": The Experiences of American Red Cross Clubmobile Women during World War II
}

Paige Gulley

Chapman University, gulle105@mail.chapman.edu

Follow this and additional works at: https://digitalcommons.chapman.edu/war_and_society_theses

Part of the United States History Commons, and the Women's History Commons

\section{Recommended Citation}

Gulley, Paige N. "'After all, who takes care of the Red Cross's morale?': The Experiences of American Red Cross Clubmobile Women during World War II." Master's thesis, Chapman University, 2020.

https://doi.org/10.36837/chapman.000200

This Thesis is brought to you for free and open access by the Dissertations and Theses at Chapman University Digital Commons. It has been accepted for inclusion in War and Society (MA) Theses by an authorized administrator of Chapman University Digital Commons. For more information, please contact laughtin@chapman.edu. 
“After all, who takes care of the Red Cross's morale?": The Experiences of American Red Cross Clubmobile Women during World War II

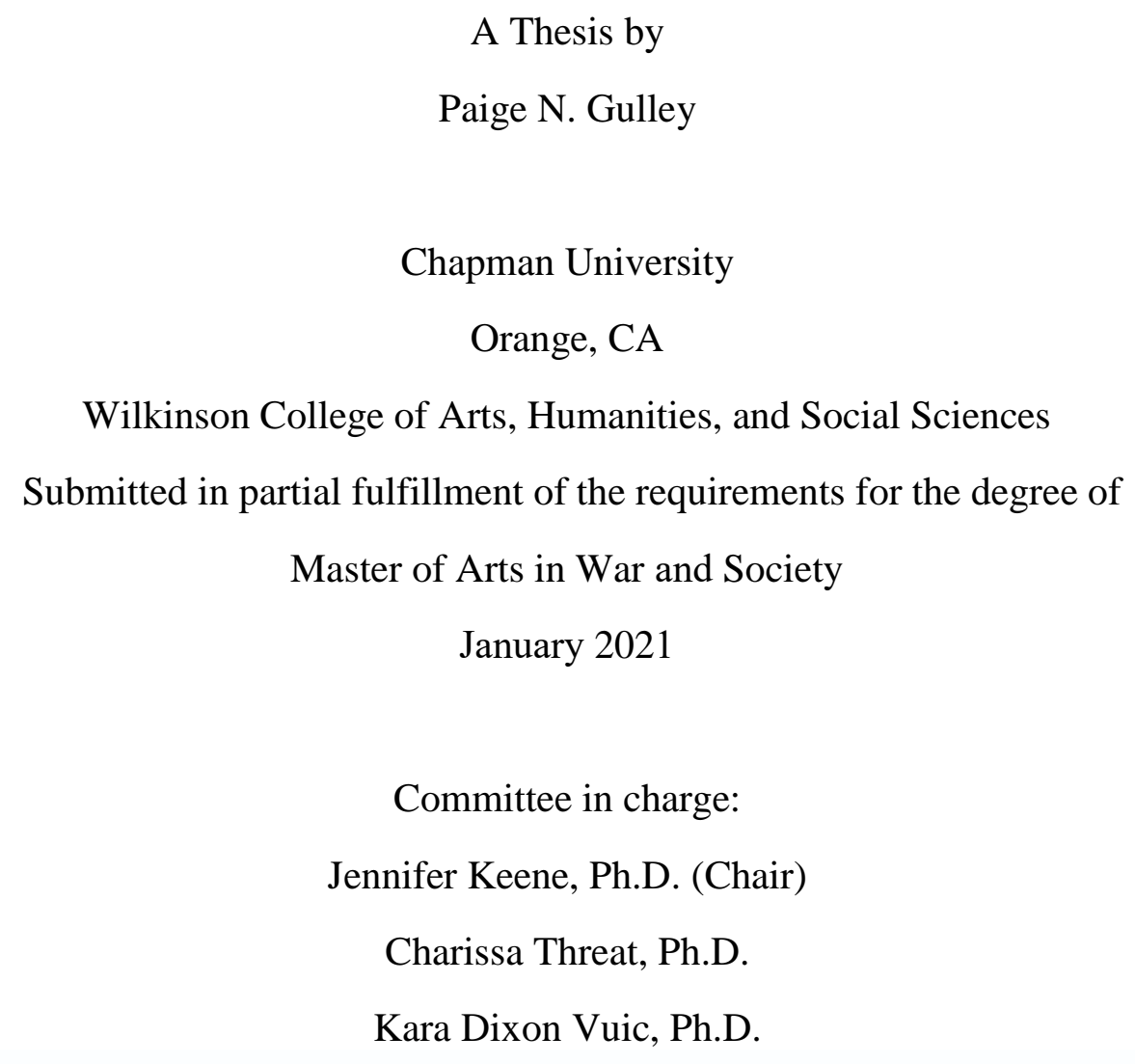

A Thesis by

Paige N. Gulley

Chapman University

Orange, CA

Wilkinson College of Arts, Humanities, and Social Sciences

Submitted in partial fulfillment of the requirements for the degree of

Master of Arts in War and Society

January 2021

Committee in charge:

Jennifer Keene, Ph.D. (Chair)

Charissa Threat, Ph.D.

Kara Dixon Vuic, Ph.D. 
The thesis of Paige N. Gulley is approved.

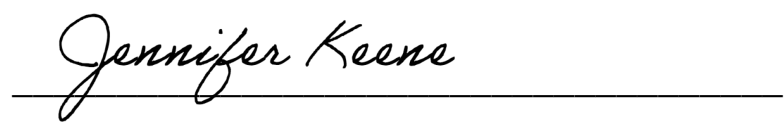

Jennifer Keene, Ph.D.

Chapman University

Thesis Director

Charissa g. Threat

Charissa Threat, Ph.D.

Chapman University

Second Reader

Kara Dixon Vuic, Ph.D.

Texas Christian University

Third Reader

July 2020 
“After all, who takes care of the Red Cross's morale?”: The Experiences of American Red Cross

Clubmobile Women during World War II

Copyright $\odot 2020$

by Paige N. Gulley 


\section{ACKNOWLEDGEMENTS}

I would like to thank my thesis advisor, Dr. Jennifer Keene, for her advice, comments, and patience in the writing of this thesis. I would also like to thank Dr. Kara Dixon Vuic for her advice and guidance, and Dr. Charissa Threat for her comments. I thank Dr. Erin Mosely for initially serving as my thesis advisor and for her understanding and support when I decided to completely change my topic halfway through the process.

I will be eternally grateful to the many professors, both in the History Department and outside it, whom I have had the pleasure of learning from during my time at Chapman University.

And finally, thank you to my friends and companions on my academic journey. You played a large part in maintaining my own morale. 


\begin{abstract}
"After all, who takes care of the Red Cross's morale?": The Experiences of American Red Cross Clubmobile Women during World War II

by Paige N. Gulley
\end{abstract}

This thesis examines the experiences of the women who served in the American Red Cross Clubmobile Service in the European Theater of Operations during World War II. Their job required them to travel through England, France, and even Germany in converted buses and 2 1/2 ton trucks, serving coffee, donuts, and a smile to soldiers just off the front lines. Though considered essential to maintaining soldiers' morale, historians have virtually ignored these women's experiences and role in the war. The inattention to their participation by the academic community parallels the disregard the women faced during the war. Clubmobile women encountered the strain and dangers of war armed with minimal training and virtually no psychological preparation for what they might face; however, they were expected, and indeed relied upon, to bolster the morale of men who had often just come from the front. By focusing on clubmobile women's role in maintaining soldiers' morale, the Red Cross and the military neglected to recognize that the morale of their female workers was equally important. Through an examination of documents written by various clubmobile women, this thesis explores how women coped with both highly gendered expectations and the experience of war itself. Clubmobile women came to rely on one another to navigate the challenges they faced and to do their job effectively. The camaraderie amongst them was a result not only of their shared experiences, but also of their status as noncombatants and their gender. Ultimately, this research seeks not only to answer the question "who takes care of the Red Cross's morale?" but also to illuminate the circumstances that make this query necessary. 


\section{TABLE OF CONTENTS}

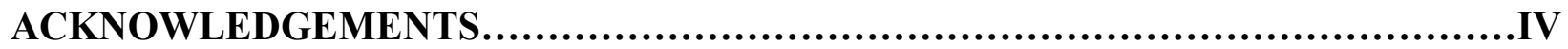

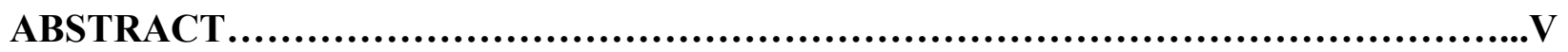

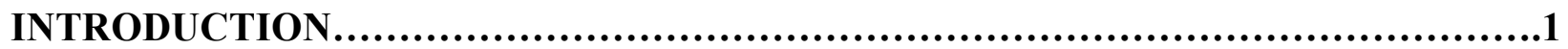

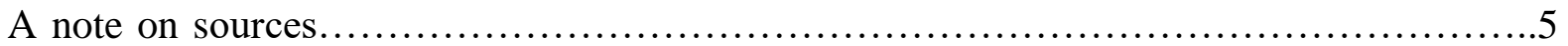

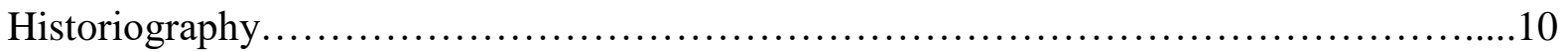

Gender roles during the Second World War......................................10

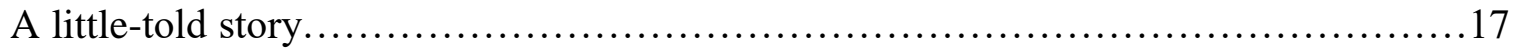

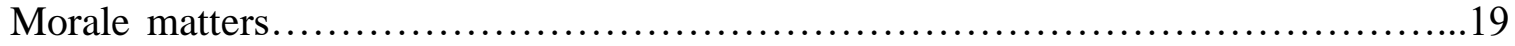

CHAPTER 1: Creating the American Red Cross Clubmobile Service.......................24

Military morale services during World War II.......................................25

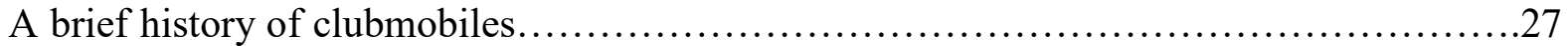

A day in the life of a clubmobiler.................................................... 31

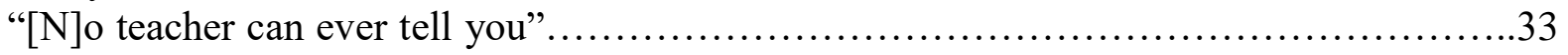

"Leaves were necessary from time to time, just to keep going"............................39

CHAPTER 2: A "forward element in the war against Germany": Clubmobilers

on the front lines...........................................................................43

"[M]ore freedom than many soldiers" ..............................................44

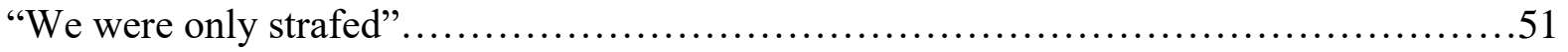

“"If you are lucky, you'll be captured"”............................................58

"[P]eaceful things crumble and disappear"..........................................61

CHAPTER 3: A "nerve racking business": The emotional challenges of clubmobiling......69

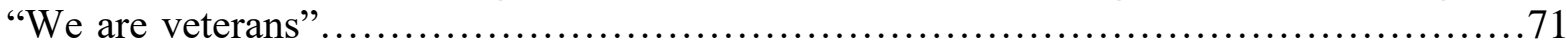

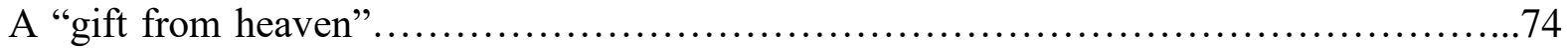

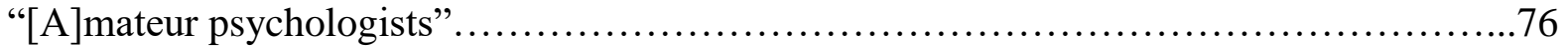

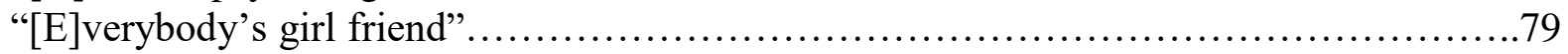

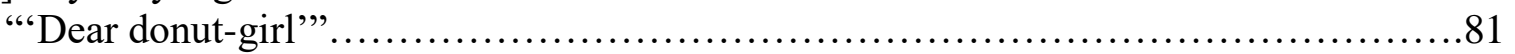

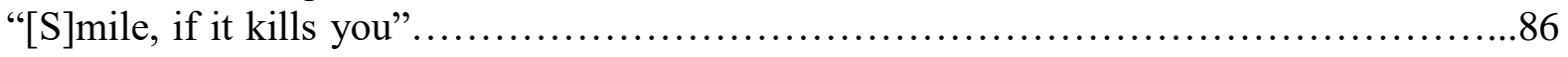

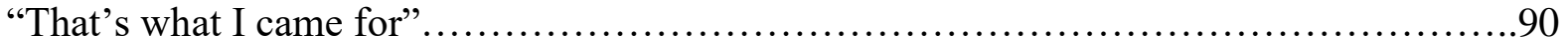

CHAPTER 4: Sisterhood: Coping with war..............................................95

Official concern (or lack thereof) with Red Cross morale................................996

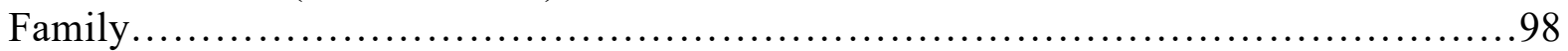

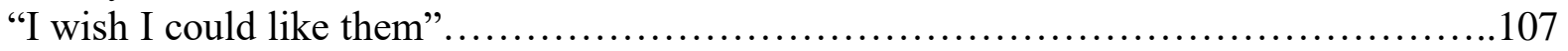

"The friends you come to treasure" ................................................ 112

"We should never have been split up [...] in the first place"...........................119

CHAPTER 5: "[W]e've grown beyond their understanding": Homecoming

and beyond............................................................................126

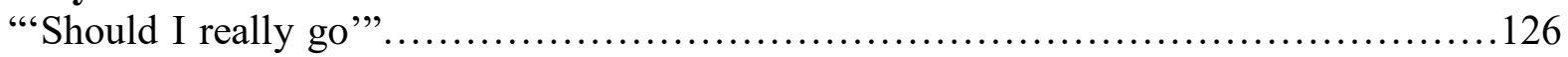


"“I didn't have anything in common with anyone back here"”..........................129

Not just "for the duration"..........................................................

Clubmobilers' legacy: Vietnam.................................................. 136

CONCLUSION.........................................................................139

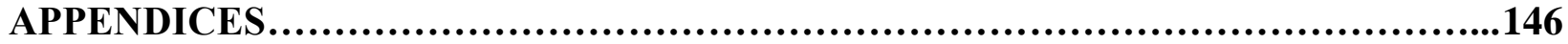

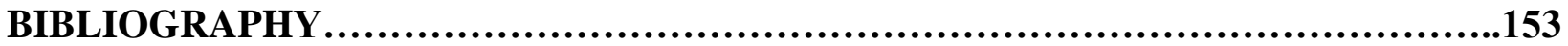




\section{Introduction}

On the continent, we lived in tents and under conditions almost as bad as his. We knew long hours in the open, in rain, snow and mud. We saw him wounded in body and mind. We saw him come from the foxhole and helped him cast off, for a while at least, the everpresent fear of the nearness of death and to forget the dirt and misery and loneliness of the infantryman's life. We saw him dirty as only an infantryman can get.

We listened to his tales of combat and his worries and joys of letters from home. We looked at millions of pictures of babies, wives, sweethearts and mothers. ${ }^{1}$

Proximity to the lines and the nature of her job meant this American Red Cross clubmobiler experienced the war intimately. ${ }^{2}$ During the Second World War, hundreds of female Red Cross volunteers worked in clubmobiles on the Western Front, travelling through England, France, and even Germany. Similar to today's food trucks, clubmobiles contained a small kitchen from which their all-female staff served coffee and donuts to soldiers. ${ }^{3}$ They also provided items like writing paper, candy, and cigarettes, as well as music and other entertainment when possible.

The women who staffed these "clubs on wheels" had to navigate both life near the front lines and the gendered expectations of their job. ${ }^{4}$

In his biography of clubmobile dock worker Elizabeth "Liz” Richardson, historian James

H. Madison argues, "Without firing a weapon Liz Richardson came to know war-far better than

\footnotetext{
${ }^{1}$ Marjorie Lee Morgan (ed.), The Clubmobile-The ARC in the Storm: A Personal History Of and By The Clubmobilers In The European Theater of War During World War II (St. Petersburg, FL: Hazlett, 1982), 178. Throughout this thesis, I will use "the Continent" as it is used in this and other quotes to connote the area of Western Europe covered by clubmobiles between summer 1944 and summer 1945. This includes France, Belgium, Luxembourg, the Netherlands, Germany, and Austria. I use "the Continent" rather than "Western Europe" because the latter often includes Spain, Portugal, and Italy, which were not served by the clubmobiles discussed here.

${ }^{2}$ The term "donut dolly" is familiar to many historians who study the Vietnam era and has been used by some authors in their brief mentions of clubmobile services during the Second World War. However, I have not found this term used by the women themselves; they referred to themselves most often as "clubmobilers." Other terms, such as "dough girl," seem to be a matter of personal preference. The most standardized word I have found is "clubmobiler," so I will employ this term to refer to the women who operated clubmobiles.

${ }^{3}$ Any use of the term "soldiers" in this paper, unless otherwise specified, refers to male soldiers. This is not only because "male" would have been implied for World War II-era individuals, but also because clubmobilers rarely came into contact with the female military corps created during World War II, for their primary mission was to raise the morale of frontline and combat troops.

${ }^{4}$ American National Red Cross, Red cross service record: accomplishments of seven years: July 1, 1939-June 30, 1946 (Washington, D.C.: Office of Program Research, The American National Red Cross, 1946), 38, https://babel.hathitrust.org/cgi/pt?id=uiug.30112072374926;view=1up;seq=48.
} 
most Americans at home and even better than many men overseas. ${ }^{, 5}$ However, the value of clubmobilers' experiences went unnoticed by any except the women themselves due to contemporary gender notions that defined expectations and acceptable behavior for women. Indeed, one clubmobiler commented, "Few persons were able to visualize just what we did and how we did it." ${ }^{\prime 6}$ Sent near the front lines to raise soldiers' morale, clubmobile women were expected to be on the job anytime and anywhere the men required them. When the women faced danger, instead of challenging prescribed gender roles, these assignments were justified because they ultimately benefitted the soldiers; indeed, military officials not only accepted but embraced clubmobilers' efforts. However, soldiers and Red Cross officials failed to recognize the strain that these activities placed on clubmobilers and rarely considered the women's well-being.

The US military and the Red Cross expected clubmobilers to represent civilian life, serve as a moralizing influence, and most importantly, maintain soldiers' morale. As primarily white, middle-class women, clubmobilers were believed to be uniquely suited for this role, due in part to the "assumption that white middle-class women were inherently sexually respectable," a point historian Meghan Winchell highlights. ${ }^{7}$ All Red Cross clubs and services were available to any soldier, regardless of race, but the organization's "integrationist" policy stated that it would staff clubs to best serve the population, effectively segregating workers. ${ }^{8}$ Though there were a few

\footnotetext{
${ }^{5}$ James H. Madison, Slinging Doughnuts for the Boys: An American Woman in World War II (Bloomington, IN: Indiana University Press, 2007), x.

${ }^{6}$ Gretchen Schuyler, "Operational Outline History of the American Red Cross Clubmobile Group 'F' while Serving in England * France * Belgium * Luxemburg * Germany during World War II," foreword, Box 2, unlabeled folder, Papers of Gretchen Schuyler, 1917-2002 (2005-m150 - 2006-m174), Schlesinger Library, Harvard University, Cambridge, MA.

${ }^{7}$ Meghan K. Winchell, Good Girls, Good Food, Good Fun: The Story of USO Hostesses during World War II (Chapel Hill: University of North Carolina Press, 2015), 5,

http://libproxy.chapman.edu/login?url=https://search.ebscohost.com/login.aspx?direct=true\&AuthType=ip,uid\&db= nlebk\&AN=275333\&site=eds-live\&ebv=EB\&ppid=pp_Cover.

${ }^{8}$ Kara Dixon Vuic, The Girls Next Door: Bringing the Home Front to the Front Lines (Cambridge, MA: Harvard University Press, 2019), 122.
} 
Black clubmobile crews serving in the United Kingdom (UK), clubmobilers were primarily white. 9

From the beginning of US involvement in World War II, the military believed that the presence of women overseas was essential to soldiers' morale. During the First World War, the military had relied on women working in YMCA and Salvation Army canteens to serve as mother figures, maintaining soldiers' morale and morality. ${ }^{10}$ In World War II, the Red Cross and United Service Organizations (USO) supplied similar workers. Red Cross women were no longer expected to be mother figures, but to represent the young, innocent "girl next door," as historian Kara Dixon Vuic argues. ${ }^{11}$ They symbolized the American home front, serving as a tangible reminder of the soldier's civilian life and a physical representation of his country and its support for his efforts. This reminder was also intended to deter soldiers from seeking the company of prostitutes and provide a welcome respite from the all-male environment of war, allaying fears that exposure to solely male companionship would lead to homosexuality among soldiers. ${ }^{12}$ Red Cross women's main role, however, was to maintain soldiers' morale. Their presence was expected, Vuic asserts, “to ease the men's mental stress.” Many soldiers found it easier to talk to a woman than to other soldiers, and Vuic argues that some officials believed that having women available for the soldiers to talk to "was better for the men than sending them to psychiatrists."13

However, in focusing on their role in maintaining soldiers' morale, the Red Cross neglected the morale of its female workers. Clubmobile women faced many of the same stresses as the soldiers they served, from the physical danger of living and working close to the front

\footnotetext{
${ }^{9}$ J. Clarice Brooks, “Aboard the Massachusetts," Sinker, Dec. 9, 1943. I did not have access to any documents or records from Black clubmobilers beyond mentions in the clubmobile newspaper. As such, all the clubmobilers I discuss here were white.

${ }^{10}$ See Vuic, The Girls Next Door, "Chapter 1: A New Kind of Woman is Following the Army."

${ }^{11}$ See Vuic, The Girls Next Door, especially Chapters 2-3.

${ }^{12}$ Vuic, The Girls Next Door, 66.

${ }^{13}$ Vuic, The Girls Next Door, 109-10.
} 
lines to the psychological stresses of befriending men who had experienced the horrors of war or could soon be killed. Due in part to the lack of official services to help them deal with the emotional stresses of their job, clubmobilers formed strong bonds with one another. Elizabeth "Bettie" Walters noted casually in a letter home, "Of course all us gals whether we know each other or not feel like we are one big family." 14 These connections, this sense of being "one big family," were essential in maintaining clubmobile women's morale and allowing them to continue doing their job of supporting soldiers. The Red Cross' failure to recognize the importance of these connections was a symptom of the broader failure, by the Red Cross, the military, and the public, to acknowledge the importance of women's experiences in their own right, not merely in their effect on men.

Clubmobilers were complicit in the subordination of their own needs to those of the soldiers. Antonio Gramsci's theory of cultural hegemony defines a culture as "hegemonic" when it becomes common sense to the members of that culture. ${ }^{15}$ Because it is common sense, the subjects consent to their domination and control by the dominant ideology. ${ }^{16}$ In the case of clubmobilers, the women accepted that their main role was to support male soldiers, and they did their best to fulfill this role, sometimes at the cost of their own well-being. Ultimately, the challenges of living in a war zone and placing the men's needs above their own led the women to develop strong bonds with one another. Clubmobilers built a family on the battlefield, not only formed by their exposure to the violence of war but also a product of their identity as women, specifically clubmobile women. Even as they accepted the prioritization of the men's well-being

\footnotetext{
${ }^{14}$ Elizabeth "Bettie" Walters to Mr. \& Mrs. Aaron Walters (parents), 28 March 1944, Walters Family Second World War Correspondence (2017-308-w-r), Center for American War Letters, Chapman University, Orange, CA (hereafter Walters Family Correspondence).

${ }^{15}$ Stephen Duncombe, "Cultural Hegemony," in Beautiful Trouble: A Toolbox for Revolution, eds. Andrew Boyd and Dave Oswald Mitchell (New York; London: OR Books, 2012), 222-5, www.jstor.org/stable/j.ctt1bkm5nd.94. ${ }^{16}$ Molly Merryman, "Recognizing the Gendered Warrior: History and Theory Intersect with the Fate of the WASPs," in Clipped Wings: The Rise and Fall of the Women Airforce Service Pilots (WASPS) of World War II (New York: NYU Press, 1998), 158, https://www.jstor.org/stable/j.ctt9qgb65.14.
} 
over their own, clubmobilers' friendships allowed them to work within this gendered hierarchy of needs to ensure that one another's morale was not neglected.

\section{A note on sources}

Because this thesis focuses on the everyday experiences of clubmobile women, I rely primarily on the records they produced. A few of these have been published, consisting of three memoirs, two edited letter collections, and a biography. ${ }^{17}$ I also draw extensively from archival collections of clubmobilers' papers. I first discovered the clubmobile service through the wartime correspondence of Bettie Walters, housed at Chapman University's Center for American War Letters. ${ }^{18}$ Further research led me to the archives of Harvard University's Schlesinger Library, whose Collection of the American Red Cross Clubmobile Service contains material from twenty-eight different clubmobilers, consisting primarily of correspondence, though it also includes unpublished memoirs, newspaper clippings, official documents, and other miscellaneous papers and objects. ${ }^{19}$ In addition to the Clubmobile Service Collection, the Schlesinger Library holds the papers of two other clubmobilers, Mary Churchill Small and Gretchen Schuyler, which are primarily composed of the women's wartime correspondence. ${ }^{20}$ Gretchen Schuyler served as captain of Clubmobile Group F, so her papers also include official

\footnotetext{
${ }^{17}$ Memoirs: Eva Maria Johnson, I Too Shall Wear Purple (New York: Carlton Press, 1987); B.J. Olewiler, A Woman in a Man's War (Xlibris, 2003); and Oscar Whitelaw Rexford (ed.), Battlestars \& Doughnuts: World War II Clubmobile Experiences of Mary Metcalfe Rexford (St. Louis: The Patrice Press, 1989). Edited letter collections: Rosemary Norwalk, Dearest Ones: A True World War II Love Story (New York: John Wiley \& Sons, Inc., 1999), and Angela Petesch, War Through the Hole of a Donut (Madison, WI: Hunter Halverson Press, 2006). Biography: Madison, Slinging Doughnuts for the Boys.

${ }^{18}$ Walters Family Second World War Correspondence (2017-308-w-r), Center for American War Letters, Chapman University, Orange, CA.

${ }^{19}$ Collection of the American Red Cross Clubmobile Service, 1940-1998 (inclusive), 1943-1946 (bulk) (MC 550), Schlesinger Library, Harvard University, Cambridge, MA.

${ }^{20}$ Papers of Mary Churchill Small, 1943-1947 (2010-m129), Schlesinger Library, Harvard University, Cambridge, MA, and Papers of Gretchen Schuyler, 1917-2002 (2005-m150-2006-m174), Schlesinger Library, Harvard University, Cambridge, MA.
} 
reports and schedules that provide invaluable insight into the day-to-day operations of a clubmobile group, as well as various physical objects, including her uniform. ${ }^{21}$

In addition to these archival documents and memoirs, Marjorie Lee Morgan's book The Clubmobile-The ARC in the Storm: A Personal History Of and By The Clubmobilers In The European Theater of War During World War II was an invaluable resource. Published in 1982, it is the only comprehensive account of clubmobilers' experiences. The first half of the book provides a history and overview of clubmobile operations in the UK from their inception in late 1942 to preparation for crossing the English Channel in the summer of 1944. The second half is devoted to the ten clubmobile groups that operated on the Continent from the summer of 1944 until the war's end. Information provided by group members includes a group roster, significant group milestones, and a brief account of the group's experiences. ${ }^{22}$

In addition to these personal papers and accounts, I consulted the clubmobile newspaper, The Sinker, named after the donuts the women served. The Schlesinger Library holds original issues of The Sinker from August 1943 to May 1945. Though it was published by Red Cross headquarters and often included official reminders, The Sinker tried to assuage doubts that it was propaganda; its editors were clubmobilers themselves, and it encouraged the submission of content from clubmobile women whenever possible. As such, it often ran irreverent, tongue-incheek stories designed to poke fun not only at clubmobile life in general, but also at Red Cross officials. However, none of these stories ever represented a serious critique of officials or clubmobile life; suggestions that headquarters was disorganized and out of touch with clubmobilers were always couched in a jocular tone of exasperated resignation to the fact that

\footnotetext{
${ }^{21}$ For a full list of the women whose papers are referenced here, as well as basic information on their Red Cross service (when available), see Appendix III.

${ }^{22}$ About half of the groups credit the author of these accounts, while the others do not. Many group rosters appear to list only original members, while others include those who joined the group while it was operating on the Continent.
} 
this was how things were, and there was nothing to be done but accept it. Many stories submitted by clubmobile crews were wryly self-deprecating, and mentions of the stresses of clubmobile life were framed with wit and humor; one crew, for example, wrote several accounts of a mischievous family of "Doughlins, double first cousins to the gremlins," purportedly responsible for the spills, malfunctions, and general chaos of clubmobile service. ${ }^{23}$ The few serious recognitions of clubmobilers' difficulties came in messages from headquarters admonishing the women to place the soldiers' interests above their own. As such, The Sinker provides insight into how Red Cross headquarters encouraged clubmobilers to understand their role. Despite their largely lighthearted tone, the many stories submitted by the women also point to common difficulties both with Red Cross officials and in the everyday experience of clubmobiling.

I also refer to a small number of publications that provide an overview of Red Cross services during the war, many published by the Red Cross itself. The most notable of these is $A t$ His Side: The Story of the American Red Cross Overseas In World War II, by George Gershon Korson. ${ }^{24}$ Korson provides a comprehensive overview of the Red Cross' wartime services, drawing on official Red Cross reports, the Red Cross Courier, and interviews and accounts from Red Cross workers.

Scholars have debated the merits and pitfalls of letters, especially war letters, for decades. In one of the strongest objections to the use of letters to depict wartime experience, Paul Fussell asserts, "any historian would err badly who relied on letters for factual testimony about the war." ${ }^{25}$ He believes that soldiers rely on self-censorship to protect loved ones from the horrors of

\footnotetext{
23 "Read it and Weep," Sinker, Sept. 29, 1943.

${ }^{24}$ George Gershon Korson, At His Side: The Story of the American Red Cross Overseas In World War II (New York: Coward-McCann, Inc, 1945), https://babel.hathitrust.org/cgi/pt?id=mdp.39015031930426\&view=1up\&seq=284.

${ }^{25}$ Paul Fussell, The Great War and Modern Memory (London: Oxford University Press, 1975), 183.
} 
war, and thus letters do not provide an accurate account of wartime experiences. ${ }^{26}$ However, only one chapter after his stringent objections, Fussell himself quotes a letter in which a soldier describes the seeming pointlessness of the death of a comrade. ${ }^{27}$ Fussell's use of this letter not only contradicts his own objections to their validity as sources, but also highlights the fact that letters are one of the few sources available for studying wartime experiences. Memoirs, the other commonly used source on this subject, present their own challenges, namely the amount of time that has passed between the events described and the publication of the memoir itself. What the memoir provides in (presumed) lack of censorship is counterbalanced by its temporal separation from the events it narrates, while the opposite is true for letters.

In the unedited letters from Red Cross clubmobile women used in this paper, both censorship and self-censorship are evident. Official censorship is notable both in its prevalence and in the ease of circumventing it: some letters have been overtly censored, with entire paragraphs cut out, while others reveal a surprising amount of information about locations and/or events. Indeed, considering that statements concerning "morale [...] of US or allied military forces" were prohibited by official censorship regulations, it is amazing that any information on clubmobilers' work made its way to their families. ${ }^{28}$ Though self-censorship can be more difficult to identify, it is apparent in the differences in content between letters from the same clubmobiler to different recipients. The Bettie Walters collection, for example, is composed primarily of letters to her parents, but also contains a few letters sent to one of her brothers, who was serving in the US Army in the Mediterranean Theater, and to a close female friend at home.

\footnotetext{
${ }^{26}$ Paul Fussell, Wartime: Understanding and Behavior in the Second World War (New York: Oxford University Press, 1989), 145.

${ }^{27}$ Fussell, Wartime, 179.

28 "Censorship Instructions, Postal and Cable," ETOUSA Headquarters, 12 March 1944, Virginia Storts Hall, Box 2, Folder 10, Collection of the American Red Cross Clubmobile Service, 1940-1998 (inclusive), 1943-1946 (bulk) (MC 550), Schlesinger Library, Harvard University, Cambridge, MA (hereafter Clubmobile Service Collection).
} 
Bettie's letters to her brother and her friend were much more candid about the dangers of life near the front lines than those sent to her parents. These differences in content based on recipient indicate a conscious effort on Bettie's part to prevent her parents from worrying about her; in fact, she often blamed her lack of detail on official censorship regulations, demonstrating that her omissions when writing to her parents were indeed purposeful.

Memoirs are also valuable sources in the examination of wartime experience, for the immediacy of letters and the retrospect of memoirs offer slightly different types of information. Often, memoirs reflect more broadly on the writer's experiences, specifically the benefits of companionship and the lifelong friendships that were formed, while letters tell of day-to-day bonding and shared experiences, vignettes that would later be forgotten, yet were nevertheless significant. Tales of everyday problems or arguments are also largely missing from memoirs, while letters and other documents created during the war catalog such incidents.

In addition to several memoirs, I also draw upon two edited letter collections for this paper: War Through the Hole of a Donut, by Angela “Angie" Petesch, and Dearest Ones, by Rosemary "Rosie" Langheldt Norwalk. Angie admits that she has "edited those letters and arranged them $[\ldots]$ deleting such personal bits as 'please send me sweaters and sardines.",29 Rosie too notes, “The letters are edited for length and excess adverbs and adjectives [...], and the documents and notes edited from the originals, journal notes reconstructed from tablet notes not sent home. Only two or three names have been changed to prevent embarrassment all around."30

\footnotetext{
${ }^{29}$ Petesch, War Through the Hole of a Donut, ix. Many of Angie Petesch's original letters are part of Harvard University's Clubmobile Service Collection. In comparing the original letters with the published collection, it appears that the deleted segments concern requests for supplies and relationships with friends and relatives at home that would require extensive background knowledge to understand. As such, I believe the published letters are an accurate account of Angie's wartime experience, and I cite the published letters for ease and clarity of citation. ${ }^{30}$ Norwalk, Dearest Ones, xi.
} 
Such admissions beg the question of what else has been edited out, and whether the published letters represent the entirety of their authors' wartime correspondence.

\section{Historiography}

Several areas of scholarly literature are relevant in examining the experiences of American Red Cross clubmobile women. The vast body of literature concerning gender and women's roles during World War II provides important context for the clubmobiler's role as, first and foremost, a female presence at the front lines. The much-less-researched area of recreation workers' experiences overseas, both during the Second World War and throughout the twentieth century, provides insights into the more specific challenges clubmobilers faced, though few scholars have studied clubmobilers specifically. Finally, an examination of literature on morale, especially on the front lines, is essential to understanding clubmobilers' need for morale services and the significance of their mutual support in the absence of official services.

\section{Gender roles during the Second World War}

Many scholars have examined women's roles and gender norms during the Second World War. The majority of such works can be divided into two broad categories: women on the home front and servicewomen. Studies of wartime gender roles across these categories agree that women's role in society did not undergo significant shifts as a result of World War II because the war was portrayed as a temporary departure from societal norms that required women to move into unusual positions.

On the home front, World War II was framed as a temporary emergency which expanded a woman's traditional role of supporting her husband or male relatives to include working outside the home. Maureen Honey, for example, finds that recruitment and demobilization propaganda portrayed women's war work as the female equivalent of serving in the military, 
implying the same impermanence. As the war ended, women were pressured to return to prewar positions in the home or "pink collar" jobs. ${ }^{31}$ Clubmobilers' experiences often reflected this understanding of the impermanence of women's wartime roles, for the majority of clubmobile women had no interest in a Red Cross career following the war, but rather viewed their service, like male military service, as a wartime departure from their everyday lives.

In her study of the portrayal of the female body during World War II, Adison Beals finds that, "The gentleness and care associated with women was $[\ldots]$ being commodified as a tool to aid the war effort." ${ }^{, 32}$ She argues that Norman Rockwell's image of Rosie the Riveter- "a brawny, red-haired factory worker eating a sandwich as she looks over a factory floor"suggests the image of a mother supervising her children, creating a "war worker-caretaker hybrid. ${ }^{33}$ Significantly, this Rosie continues to work even during her lunch break, highlighting her commitment to the war effort and emphasizing the fact that a woman's role as a caregiver was not merely a nine-to-five job, but a part of her identity, expected 24/7. Beals' observations on the commodification of the traditional female caregiver role are essential in understanding clubmobilers' role in the war effort and emphasize the women's difficulties in escaping the expectations placed upon them.

Similarly, Melissa McEuen's Making War, Making Women examines the efforts of government propaganda and corporate advertising to define the stereotypical American woman. McEuen argues that images were carefully curated to emphasize women's patriotism because

\footnotetext{
${ }^{31}$ Maureen Honey, "The 'Womanpower' Campaign: Advertising and Recruitment Propaganda during World War II," Frontiers: A Journal of Women Studies 6, no. 1/2 (Spring-Summer 1981): 50-6, https://www.jstor.org/stable/3346491.

${ }^{32}$ Adison Beals, "The Anatomy of Patriotism: The Commodification of American Gender Roles and the Female Body in World War II Print Media," Voces Novae 11 (2019): 9, https://digitalcommons.chapman.edu/vocesnovae/vol11/iss1/1.

${ }^{33}$ Beals, "The Anatomy of Patriotism," 10-1.
} 
"social order [was] as high a cultural priority as economic and political order." ${ }^{34}$ Appeals to a woman's self-interest that emphasized extra wages, new skills, and the adventure of exploring new roles were always offset with patriotic language. "Women were not to be encouraged to consider themselves independent operators separate from a larger national cause," she asserts. ${ }^{35}$ McEuen's research highlights an important aspect in the portrayal of female wartime service that is reflected in the patriotic tone of many clubmobilers' accounts of their service.

Other propaganda campaigns illustrated how and why housewives played an essential role in winning the war. Sara Harrington argues that wartime propaganda depicted the American housewife as having a direct impact on the war effort overseas while also preserving her femininity. She finds that many posters portray women's hands reaching out to the American soldier, yet few depict women's eyes or faces, signifying that while women should act for the war effort, they must never be allowed to actually witness the violence of war. ${ }^{36}$ Robert Westbrook illuminates this division of roles with his study of World War II-era pin-ups, arguing that propaganda and societal norms urged men to protect their women, creating a private, moral obligation that relied on contemporary gender roles to encourage American men to join the military. The male-protector-female-protected dichotomy was enhanced by pin-ups, which Westbrook asserts not only had sexual appeal but were also representative of the average American girl. He examines the popularity of Betty Grable pin-ups, which were not very sexual or revealing, and argues that Grable's popularity was due to her ordinariness, which allowed her to represent the average soldier's wife or girlfriend; in fact, Westbrook highlights that Grable's

\footnotetext{
${ }^{34}$ Melissa A. McEuen, Making War, Making Women: Femininity and Duty on the American Home Front, 1941 1945 (Athens, GA: University of Georgia Press, 2010), 204, https://search-ebscohostcom.libproxy.chapman.edu/login.aspx?direct=true \&AuthType=ip,uid\&db=nlebk\&AN=375875\&site=eds-live.

${ }^{35}$ McEuen, Making War, Making Women, 192.

${ }^{36}$ Sara Harrington, "Women's Work: Domestic Labor in American World War II Posters," Art Documentation 22, no. 2 (2003): 41-4, http://eds.b.ebscohost.com.libproxy.chapman.edu/eds/pdfviewer/pdfviewer?vid=3\&sid=1579069c-43b7-4e39-ba9b1f94663ec049\%40pdc-v-sessmgr03.
} 
popularity increased after she married Harry James and had a child in $1943 .{ }^{37}$ Like Grable, clubmobilers were expected to represent the average American girl, and their duties were carefully crafted so that their job appeared to remain within the confines of a woman's role, though many of their experiences challenged this neat categorization.

In addition to supporting the war effort from their kitchens or on factory floors, women could also choose to join the USO or enlist in a female military corps during World War II. In Good Girls, Good Food, Good Fun, Meghan Winchell examines the role of USO hostesses in maintaining soldiers' morale during the Second World War. Winchell argues that the USO “mobilized [women on the home front] to perform 'women's' work that did not challenge gender norms." ${ }^{38}$ Like clubmobile workers, USO hostesses were expected to keep soldiers' morale high by "maintain[ing] the humanity of the individual wearing the uniform." "39 Hostesses' duties included sewing and cooking for soldiers, allowing them to serve as substitute wives and mothers. However, Winchell highlights that hostesses were also expected to police men's sexuality, providing them with socially acceptable "physical contact to be a substitute for sexual intercourse." ${ }^{40}$ A wholesome alternative to prostitutes, "hostesses became public women;" Winchell asserts that the USO carefully screened and regulated its hostesses to maintain their "good girl" image, in opposition to "bad girls" who tempted men and spread venereal diseases. ${ }^{41}$

While USO hostesses represented the socially acceptable "good girl," servicewomen challenged traditional female roles. Histories of female military corps during World War II emphasize the obstacles servicewomen faced as a result of contemporary notions of gender and

\footnotetext{
${ }^{37}$ Robert B. Westbrook, “'I Want a Girl, Just Like the Girl that Married Harry James': American Women and the Problem of Political Obligation in World War II," American Quarterly 42, no. 4 (Dec., 1990): 587-614, https://www.jstor.org/stable/2713166.

${ }^{38}$ Winchell, Good Girls, Good Food, Good Fun, 1.

${ }^{39}$ Winchell, Good Girls, Good Food, Good Fun, 7.

${ }^{40}$ Winchell, Good Girls, Good Food, Good Fun, 107-8.

${ }^{41}$ Winchell, Good Girls, Good Food, Good Fun, 116.
} 
duty, and the need to portray their service in ways that did not overtly challenge such ideas. Historian Charissa Threat asserts that women in the military were kept "as far away as possible from any suggestion of combat duty." ${ }^{, 2}$ Indeed, Melissa Murray argues that women's military service during World War II was always in support roles, allowing men to do the "real" military work of defending the nation. As a result of this gendered separation of work, women's military service during the war actually reinforced gender norms. ${ }^{43}$

Leisa Meyer's Creating G.I. Jane highlights the gendered objections to female military service, including fears of lesbianism and disruption of the social order. She argues that Women's Army (Auxiliary) Corps (WAAC/WAC) leaders strictly regulated female recruits' sexuality and public image, emphasizing that WACs were doing traditional women's work and arguing that the experience would make them better wives and mothers by providing insight into the military experience and valuable skills like first-aid training. Meyer demonstrates the importance of gender roles in the portrayal of female wartime service, as well as the overarching understanding that such service was an aberration from, not a redefinition of, the norm. ${ }^{44}$

D’Ann Campbell further illuminates the importance of contemporary gender norms by highlighting that the US military experimented with using women in antiaircraft (AA) units during World War II, but abandoned the idea due to prevailing notions of gender. Following the British success with mixed-gender AA units, US Army Chief of Staff George C. Marshall initiated an experiment in which a limited number of WAACs were trained to operate antiaircraft artillery units. Despite finding that the women were in many respects more competent than their

\footnotetext{
${ }^{42}$ Charissa Threat, “'Patriotism is Neither Masculine nor Feminine': Gender and the Work of War," in The Routledge History of Gender, War, and the U.S. Military, ed. Kara Dixon Vuic (New York: Routledge, 2018), 242.

${ }^{43}$ Melissa Murray, "Made with Men in Mind: The GI Bill and Its Reinforcement of Gendered Work after World War II," in Feminist Legal History: Essays on Women and Law, eds. Tracy A. Thomas and Tracey Jean Boisseau (New York: NYU Press, 2011), 84-99, https://www.jstor.org/stable/j.ctt15zc8jt.9.

${ }^{44}$ Leisa D. Meyer, Creating G.I. Jane: Sexuality and Power in the Women's Army Corps During World War II (New York: Columbia University Press, 1998).
} 
male counterparts, with the potential to fill $60 \%$ of positions in AA units, Marshall ultimately abandoned the experiment and ordered it kept confidential. His decision, Campbell argues, was due to contemporary understandings of gender roles that would not condone women being placed in any combat role. ${ }^{45}$

Female wartime roles were so constricted by cultural understandings of gender that the service of the Women Airforce Service Pilots (WASPs) was terminated before the end of the war, and they were denied official militarization until the 1970s. Molly Merryman argues that the WASPs' demise was due in large part to their blatant flaunting of gender roles by taking jobs men found desirable, for WASPs flew the newest and best military planes. Merryman finds that public criticism portrayed the WASPs as stealing these jobs from men, ignoring the fact that many of the women's missions, such as test-piloting new aircraft, were considered as dangerous as combat. Significantly, Merryman highlights the arbitrariness of definitions of "combat" and "noncombatant," which historically define combat as a singularly male endeavor. ${ }^{46}$ Her work also demonstrates the negative consequences of women being perceived as a threat to men's jobs. However, despite objections to female military service, clubmobile women were sent into an active war zone and sometimes found themselves under fire.

Because the vast majority of studies of the female experience during World War II focus on either women on the home front or servicewomen, our understanding of female roles and opportunities during this period is largely limited to these categories. In focusing on the experiences of servicewomen, constrained to "women's work" even in the military; female factory workers, represented by Rosie the Riveter; and housewives, portrayed as patriotic

\footnotetext{
${ }^{45}$ D'Ann Campbell, "Women in Combat: The World War II Experience in the United States, Great Britain, Germany, and the Soviet Union," The Journal of Military History 57, no. 2 (Apr. 1993): 301-23, https://www.jstor.org/stable/2944060.

${ }^{46}$ Merryman, "Recognizing the Gendered Warrior."
} 
through rationing, historians have relegated all World War II-era women to one of these roles. Candi Carter Olson's study of female war correspondent Ruth Cowan challenges this limited understanding by focusing on a woman who fits none of these categories. Though she was still bound by societal expectations, Cowan used her position as a war correspondent to demonstrate not only that women were capable of doing a man's job, but also that they could withstand the horrors of war, contrary to popular wisdom. Reporting from the beachhead at Normandy in the middle of a battle, Cowan emphasized that the stereotypical timidity women were expected to show did not preclude the strength that allowed her to weather the experience. ${ }^{47}$ Like Cowan, clubmobilers had firsthand experience of the war, transcending the narrow confines of "women's work" and challenging our understanding of women's roles during World War II.

Clubmobilers' experiences were a unique mix of the traditional female role and the realities of war. Their position was defined as a support role, in which they as women would boost male soldiers' morale. As a result, their methods and everyday experiences, which often challenged gender roles, were justified because they benefitted the men. Perhaps because their role was uniquely female, clubmobile women did not face the same objections that servicewomen did: they were not seen as threatening or "stealing" men's jobs, but rather meeting soldier's needs in a way that no man could. Clubmobilers' experiences suggest that historians have taken too rigid a view of gender roles during the Second World War, failing to recognize the difference between the portrayal and the realities of women's experiences and thus focusing

\footnotetext{
${ }^{47}$ Candi S. Carter Olson, “'This Was No Place for a Woman': Gender Judo, Gender Stereotypes, and World War II Correspondent Ruth Cowan," American Journalism 34, no. 4 (2017): 437, http://eds.a.ebscohost.com.libproxy.chapman.edu/eds/pdfviewer/pdfviewer?vid=1\&sid=ca5593e6-3797-4299-9ecc9ae5b4111eaf\%40sessionmgr4007. Unfortunately, Carter Olson does not recognize that war correspondents were not the only women to have such experiences. Her opening statement emphasized that Cowan was "offered the opportunity to cross the English Channel on a Liberty ship to the Normandy beachhead, a feat no woman had attempted previously" in August 1944, ignoring the fact that six clubmobile groups (some 180 women) had already landed on Utah or Omaha Beach in July 1944 (see Appendix II). Carter Olson, "“This Was No Place for a Woman," 427.
} 
more on how women were depicted than on their lived experiences of the conflict. This thesis will work to challenge this tradition, not only by examining the unconventional role of clubmobile women, but also by focusing on the women's voices, as found in letters and memoirs, rather than official reports or depictions of them.

\section{A little-told story}

While much has been written about women's experiences and gender roles during World War II, few scholars have examined the lives and experiences of female recreation workers sent abroad to maintain the morale of the troops. Indeed, the majority of scholars who recognize these women do so briefly, without extended analysis of their role in the war or their own experiences of the conflict. Many mentions of the Red Cross ignore or minimize the importance of the organization's recreation aspects. Doris Weatherford's American Women and World War II, for example, asserts, "the Red Cross's emphasis was on health, while the USO's was on recreation," thus limiting Red Cross women's experiences to nursing. ${ }^{48}$ Jeanie Sutton Lambright's They Also Served briefly mentions Red Cross club service; however, the challenges and experiences of service club workers were very different from those of clubmobilers, for most soldiers visiting clubs were on leave and, more importantly, many smaller service clubs were staffed by a single women, rather than the groups upon which clubmobiles relied. Interestingly, Lambright also mentions Elizabeth Richardson, who will be referenced in this paper, as one of four women buried at the American Cemetery in Normandy; however, Lambright refers solely to Richardson's Red Cross membership, not her specific position as a clubmobile worker. ${ }^{49}$

The few scholarly mentions of clubmobiles are brief, lacking detail and analysis. The ostensibly comprehensive American Women during World War II: An Encyclopedia, for example,

\footnotetext{
${ }^{48}$ Doris Weatherford, American Women and World War II (Edison, NJ: Castle Books, 2008), 231.

49 Jeanie Sutton Lambright, They Also Served: Women's Stories from the World War II Era (Xlibris, 2003).
} 
contains one paragraph about clubmobilers under "Red Cross"; they are also mentioned briefly in the entries on D-Day and the European Theater of Operations. However, there is little factual information on clubmobile women in this resource; one mention asserts that they had "little time to chat," when in fact conversation was one of their main duties. ${ }^{50}$ Overall, the Encyclopedia treats clubmobilers as a minor, unimportant group. Claudia Hagen's American Women During World War II also includes a chapter on the American Red Cross, calling clubmobiles "one of the most remembered services, from the soldiers' viewpoint." ${ }^{, 51}$ Hagen provides an overview of clubmobile services and mentions some of the difficulties of the women's role. However, her brief introduction to the clubmobile service ignores many of the everyday stresses and challenges the women endured due to their proximity to the front.

The only scholarly book about female recreation workers overseas, historian Kara Dixon Vuic's The Girls Next Door, focuses on military and public expectations of recreation women, as well as their own experiences and interpretations of their prescribed roles. Vuic asserts, "These women were not sideshows to American wartime and military experiences. They played a central part in national efforts to construct wartime gender roles, maintain an effective fighting force, mobilize home front support, render the military and its work palatable to the American public, and manage the American military presence in foreign countries.” Her analysis focuses primarily on the expectations placed on the women and their reflection of changing gender ideologies throughout the twentieth century. Vuic also highlights the ways women responded to these expectations "within the confines of the ideologies imposed on them to create new wartime roles and meanings for their work." ${ }^{, 52}$ Her study reveals not only the inherent contradictions in the

\footnotetext{
${ }^{50}$ Doris Weatherford, American Women during World War II: An Encyclopedia (New York: Routledge, 2010).

${ }^{51}$ Claudia Hagen, American Women During World War II (CreateSpace Independent Publishing Platform, 2015), 208.

${ }^{52}$ Vuic, The Girls Next Door, 3.
} 
expectations placed on the women but also the ways in which they attempted to navigate these conflicting messages. This thesis will build upon Vuic's work by expanding and furthering the understanding of female recreation workers during World War II, focusing on the women's response not only to gendered expectations, but also to the overwhelming disregard for their experiences and well-being that these expectations created. As such, this thesis will focus on the historical construction of gender roles and theories on military unit morale to understand clubmobile women's wartime experiences.

The only full-length work that focuses specifically on the experiences of clubmobilers, Julia Ramsey’s Master’s thesis “'Girls” in Name Only: A Study of American Red Cross Volunteers on the Frontlines of World War II," contends that the Red Cross carefully tailored the image of clubmobilers to make their role acceptable in wartime society. This allowed the women to gain the frontline access they received. However, Ramsey concludes that clubmobilers were far more than "girls," highlighting behaviors such as their adoption of GI clothing and use of alcohol to argue that the women came to identify closely with the soldiers they served. ${ }^{53}$ This thesis will also build upon Ramsey's conclusions by focusing on the women's relationships with one another, rather than with the male soldiers, ultimately examining the significance of the women's camaraderie to their morale and the broader implications of the failure to acknowledge clubmobilers' experiences.

\section{Morale matters}

In addition to women's history, studies of morale in the war zone are also essential to understanding how women experienced and coped with the environment of war. Writers such as

\footnotetext{
53 Julia A. Ramsey, "“Girls' in Name Only: A Study of American Red Cross Volunteers on the Frontlines of World War II” (Master's Thesis, Auburn University, 2011). https://etd.auburn.edu/bitstream/handle/10415/2616/ramsey_julia_ma_thesis_history_post_defense_and_AUETD_c heck_5.9.11.pdf; sequence=3.
} 
Peter Kindsvatter and Paul Fussell have extensively explored the soldier's experience and battlefield morale. ${ }^{54}$ The definition of "morale" is not fixed, as World War II-era sociologist Eduard Lindeman observed: "“Morale' is a word which can be made to mean any desirable form of conduct $[\ldots]$ in a crisis." Lindeman asserted that morale was generally comprised of, "belief that collective conduct is right conduct, confidence in the cause underlying the crisis, and voluntary submission to discipline." 55 However, Lindeman's definition tends to conflate motivation and morale, which are related but distinct phenomena. John Zentner defines motivation as "the cost-benefit rationale that soldiers make before taking action [...] rooted in the way the soldier thinks." ${ }^{56}$ Morale, on the other hand, is the soldier's overall attitude, his feeling about his life as a soldier, somewhat analogous to job satisfaction in its reflection of his enthusiasm to do as required. ${ }^{57}$ While motivations are often tied to patriotism and duty, these alone cannot maintain the spirits of either the soldier or the Red Cross worker. Indeed, many clubmobilers, driven by their sense of duty, continued to do their job even as their own morale suffered, causing them to become increasingly irritable and homesick.

The most applicable definition of morale for the clubmobilers' experience was offered by Paul McNutt, a federal security administrator, in 1940: "the concern with the individual as an individual," including "his attitudes and appreciations, his relations with his fellows, [...and]

\footnotetext{
${ }^{54}$ Peter S. Kindsvatter, American Soldiers: Ground Combat in the World Wars, Korea, \& Vietnam (Lawrence, KS: University Press of Kansas, 2003), and Fussell, Wartime.

${ }^{55}$ Eduard C. Lindeman, "Recreation and Morale," American Journal of Sociology 47, no. 3 (Nov. 1941): 394, https://www.jstor.org/stable/2769289.

${ }^{56}$ John J. Zentner, "The Morale Problem," in The Art of Wing Leadership: Zentner and Aircrew Morale in Combat (Air University Press: 2001), https://www.jstor.org/stable/resrep13783.8.

${ }^{57}$ Indeed, one former Army investigator argued at the end of the Second World War that job satisfaction was an essential element in military morale: "for the American soldier, it was very important that the job be not too greatly to his distaste and also that it appear to be worthwhile." Arnold Rose, "Bases of American Military Morale in World War II," The Public Opinion Quarterly 9, no. 4 (Winter 1945-1946): 412, https://www.jstor.org/stable/2745554.
} 
maintenance of personal ideals of conduct." ${ }^{, 58}$ McNutt's definition includes both overall attitude and enthusiasm toward daily tasks, as well as acknowledging the central role of one's companions in this phenomenon. His emphasis on recognizing the individual was a key element of a clubmobiler's job: soldiers appreciated her for her ability to see them as individuals, not mere cogs in the war machine. Ironically, this very element of morale was the one the women themselves often lacked, for clubmobilers were rarely acknowledged as individuals by anyone except one another. To the men and the organization, they were interchangeable Red Cross girls. Scholars have recognized the importance of unit cohesion as it relates to military morale for decades, and many of their observations can be applied to women in the war zone. Mark Vaitkus and James Griffith assert, "cohesion is a group-level process that increases the solidarity or bonding among group members and, in turn, enables members to withstand the enormous stresses and strains of combat." ${ }^{, 59}$ In their meta-analysis of military cohesion, Laurel Oliver et al. found that group cohesion was associated with higher satisfaction with both one's job and the military at large, as well as having a positive effect on individual well-being. ${ }^{60}$ Though these observations concern the military, clubmobilers' experiences of operating in an active war zone, often under military authority, were very similar and reflect the positive effects of unit cohesion on individual morale. Indeed, Kevin Brailey et al. found that higher levels of unit cohesion decreased the likelihood of PTSD symptoms in service members who did not engage in combat

\footnotetext{
${ }^{58}$ Paul McNutt, "Proposals for United Services of National Private Agencies in the Morale Aspects of the National Service Program," December 1940, Salvation Army War Services Subject Files, 1939-1950, The Salvation Army Archives and Research Center, Alexandria, VA, quoted in Winchell, Good Girls, Good Food, Good Fun, 81.

${ }^{59}$ Mark Vaitkus and James Griffith, "An Evaluation of Unit Replacement on Unit Cohesion and Individual Morale in the U.S. Army All-Volunteer Force," Military Psychology 2, no. 4 (1990): 223, doi:10.1207/s15327876mp0204_3. ${ }^{60}$ Laurel W. Oliver et al., "A Quantitative Integration of the Military Cohesion Literature," Military Psychology 11, no. 1 (1999): 76, doi: 10.1207/s15327876mp1101_4.
} 
but had experienced prior stress, suggesting the importance of unit cohesion in helping individuals deal with stress even if they are not directly exposed to combat. ${ }^{61}$

Though unit cohesion is not the sole factor in military morale, it was the most important aspect of clubmobile women's morale because they did not have other morale services available to them. As the people responsible for the men's morale, clubmobile women were on the job whenever they interacted with an American soldier, whether they were serving donuts or attending a dance. The women provided mutual support and guidance to one another as they faced the challenges of clubmobile life, and the relationships between them became the single most important factor in their own morale, allowing them to weather the environment of war and the added stresses of their role in it.

To understand the relationships that clubmobile women formed, and their significance in maintaining the women's morale, we need to understand clubmobilers and their experiences as a whole. Therefore, the first chapter of this thesis will detail the creation of the clubmobile service and the selection and training of the women, the limited nature of which demonstrated the Red Cross' lack of regard for its workers' individual needs. The second chapter will examine the conditions that clubmobilers faced while serving on the Continent to demonstrate that the women faced many of the same dangers and violence as the men they served. Indeed, clubmobilers were sometimes mobilized as noncombatant troops, despite their gender and lack of training. From this examination of physical conditions, I move to a discussion of the mental strains of clubmobile life, due not only to the war environment but also to clubmobilers' unique position as women responsible for soldiers' morale. The expectations of this role meant that clubmobilers

\footnotetext{
${ }^{61}$ Kevin Brailey et al., "PTSD Symptoms, Life Events, and Unit Cohesion in U.S. Soldiers: Baseline Findings from the Neurocognition Deployment Health Study," Journal of Traumatic Stress 20, no. 4 (August 2007): 495-503, https://search-ebscohost-

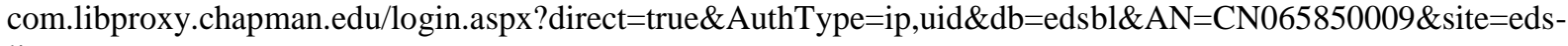
live.
} 
were on duty continuously, though soldiers and officials failed to recognize the strain this placed on the women.

The combination of these factors - lack of training and official support, physical danger, and psychological stress - meant that clubmobilers' friendships with one another became pivotal. These relationships helped clubmobilers cope with the various stresses they faced and became essential to maintaining the women's own morale. At the war's end, clubmobilers returned home to a civilian population uninterested in their wartime service. The passage of time did not diminish the women's connections to one another, even as their experiences were obscured by those of male veterans. Ignoring clubmobilers' experiences leaves us with an incomplete understanding not only of the Second World War, but also of women's roles during wartime and the experiences of noncombatants near the front lines. 


\section{Chapter 1: Creating the American Red Cross Clubmobile Service}

"To keep the morale of these young men high was the task of those who staffed the Red Cross clubmobiles," Mary "Chichi” Metcalfe recalled. ${ }^{1}$ This was no easy assignment; the military, and indeed the women themselves, expected clubmobilers to smile, lend a sympathetic ear, and help the men forget the war, at least for a moment. The Red Cross tried to select women well-suited for this job; however, their fluid hiring criteria and the minimal training the women received demonstrated that officials were far more concerned with soldiers' well-being than the women's. Clubmobilers were thrust into war with almost no preparation, forced to adapt to this harsh environment amidst a multitude of challenges that the Red Cross had not foreseen.

This thesis discusses clubmobile service in the European Theater of Operations (ETO) exclusively, focusing on clubmobiles serving on the Continent from summer 1944 to summer 1945. Not only is there far more documentation concerning clubmobiling in the ETO than any other theater, but the clubmobiles serving on the Continent had a very different experience than those stationed in the UK. ${ }^{2}$ Clubmobilers on the Continent were constantly in motion, while those in the UK worked a consistent circuit from a central base. The women on the Continent were also more removed from Red Cross headquarters, adept at improvising to get their job done while facing the dangers of living and working in an active war zone. Most significantly, clubmobilers on the Continent served soldiers fresh from the fighting, not bored men on a base. As such, clubmobile life on the Continent provides unique insight into a group of relatively untrained women who experienced war from the soldier's perspective.

This chapter will outline the creation of the clubmobile service, from its conception to the selection and training of the women who would staff it, and provide an overview of the women's

\footnotetext{
${ }^{1}$ Rexford, Battlestars \& Doughnuts, 2.

${ }^{2}$ For example, only a single folder in the eleven file boxes of Harvard University's Clubmobile Service Collection concerns a woman who served in the Mediterranean Theater; all other materials relate to service in the ETO.
} 
assigned tasks. The Clubmobile Department of the American Red Cross relied almost entirely on women; men were involved at only the highest levels of management and were therefore largely ignorant of the women's day-to-day challenges. This gave clubmobilers a great deal of freedom in their operations, and they proved adept at doing their jobs without male supervision. Most clubmobilers felt, despite their training, that they were forced to learn on the job, relying on one another to navigate the challenges of living and working under fire. The Red Cross provided little support to the women; their only recognition of the emotional difficulties of clubmobiling was the allocation of leave time, which proved both insufficient and, in many cases, impractical for the women operating on the Continent. Ultimately, only experience and camaraderie could teach a clubmobiler how to deal with the stresses of war, keep soldiers' morale high, and maintain her own composure.

\section{Military morale services during World War II}

During World War II, maintaining soldiers' morale became one of the military's top priorities, leading to the expansion of the Morale Branch of the Army, quickly renamed the Special Services Division. ${ }^{3}$ Special Services provided recreation and dining accommodations for soldiers, while the greatly expanded Post Exchange (PX) system supplied material goods like cigarettes and candy. The organizers of both Special Services and the PX system believed that it was essential to provide the citizen-soldier with the amenities of civilian life to which he was accustomed, not only to keep the soldier happy, but also to distract him from the vices that traditionally plague militaries: alcohol and women. Keeping the soldier occupied with sports or local service clubs kept him from seeking out prostitutes, and thereby reduced the rate of

\footnotetext{
${ }^{3}$ James J. Cooke, American Girls, Beer, and Glenn Miller: GI Morale in World War II, The American Military Experience Series (Columbia, MO: University of Missouri Press, 2012), 29, https://search-ebscohost-

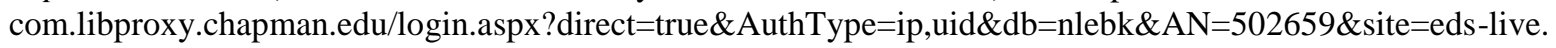


venereal disease in the military. ${ }^{4}$ Recognizing that it would be almost impossible to get soldiers to refrain from drinking altogether, the PX system sold 3.2\% beer; this cheap, American beer satisfied a soldier's craving for alcohol and greatly reduced the risk of drunkenness. ${ }^{5}$ Thus, morale services maintained not only the morale, but also the morality, of American soldiers.

As an official publication noted, "the Red Cross has been designated as the sole nonmilitary agency to provide welfare and recreation services for United States expeditionary forces," and thus their services became an important part of soldiers' lives. ${ }^{6}$ During the Second World War, the Red Cross operated a total of 989 service clubs and 319 clubmobiles. Service clubs were established in all theaters of operation for soldiers on leave. ${ }^{7}$ Initially, both clubmobile and Special Services operations were focused in the UK because officials feared that the massive influx of US troops might cause tension between the Americans and the British. ${ }^{8}$ While operating in the UK, these services were fairly stationary; clubmobiles had assigned circuits, usually visiting several bases about once a week. Following D-Day, both Special Services and Red Cross clubmobiles faced a much more fluid, mobile situation as they followed the army's advances across the Continent. However, the army felt that Special Services Companies would be a liability close to the front, despite their combat training, and mobile PX services were often curtailed. ${ }^{9}$ As such, Special Services and the PX system were still relatively stationary operations, responsible for establishing PX's and organizing movies and athletics behind the lines. Clubmobiles, on the other hand, got as close to the front as they could.

\footnotetext{
${ }^{4}$ Cooke, American Girls, Beer, and Glenn Miller, 121-2.

${ }^{5}$ Cooke, American Girls, Beer, and Glenn Miller, 34.

${ }^{6}$ American National Red Cross, Services to the Armed Forces (Washington, D.C.: The American National Red Cross, 1942), 27, https://babel.hathitrust.org/cgi/pt?id=uiug.30112076215893;view=1up;seq=33.

${ }^{7}$ American National Red Cross, Red cross service record, 38, 40.

${ }^{8}$ See Cooke, American Girls, Beer, and Glenn Miller, Chapter 4, especially pp. 61-2. Despite these efforts, American soldiers were still seen as "overpaid, oversexed, and over here" by many of the British.

${ }^{9}$ Cooke, American Girls, Beer, and Glenn Miller, 116.
} 


\section{A brief history of clubmobiles}

Clubmobiles were the brainchild of Harvey Gibson, American Red Cross Commissioner to Great Britain and Western Europe, who advocated for clubmobiles to become an integral part of Red Cross services. Some Red Cross officials felt that mobile donut kitchens were impractical, while military officials raised concerns that clubmobiles would distract soldiers who should be focused on training and fighting. ${ }^{10}$ Despite these objections, the first clubmobile went into operation in November 1942, and the military soon came to agree that clubmobiles, and their female crews, were an invaluable contribution to morale.

The original clubmobiles operating throughout the UK were single-deck buses converted to contain a donut kitchen and a small lounge area where soldiers could relax. In addition to coffee and donuts, clubmobiles distributed gum, cigarettes, and writing paper. ${ }^{11}$ Unlike service clubs, clubmobiles did not charge soldiers for their wares. Service club fees had been requested by General Dwight Eisenhower because British canteens charged for their services; since there was no British equivalent of a clubmobile, their wares were distributed free of charge to any US serviceman. ${ }^{12}$ Clubmobiles also carried a Victrola and a selection of American records to play as the women served coffee and donuts. The men loved thumbing through the records and requesting favorite songs, and one clubmobiler recalled, "the Army seemed to be under a compulsion to keep vehement time to the music coming from our record player." ${ }^{13}$ Due to the uneven numbers of women and men, many soldiers danced enthusiastically with one another.

In preparation for the Normandy invasion, the clubmobile department established ten groups to cross the Channel, where they were assigned to and based at Army and Corps

\footnotetext{
${ }^{10}$ Korson, At His Side, 266, and Morgan, The Clubmobile, 18-9.

${ }^{11}$ Korson, At His Side, 267.

${ }_{12}$ Morgan, The Clubmobile, 15.

${ }^{13}$ Olewiler, A Woman in a Man's War, 73.
} 
headquarters to serve all the units under their command. ${ }^{14}$ As the war progressed, most of the original groups were split to cover a wider area. Each group originally consisted of "twenty-nine pieces of rolling equipment," including " 8 clubmobiles, 1 cinemobile, two $2 \frac{1}{2} 2$ ton supply trucks, [...] and 2 mobile generators. ${ }^{\prime 15}$ Though converted buses were effective in even the remote parts of the UK that clubmobiles served, they were incredibly impractical for the battle-ravaged roads of Western Europe. As such, the clubmobiles sent to the Continent were converted $2 \frac{1}{2} 2$ ton GMC trucks, better able to withstand the rough roads and battlefield conditions they would face. They did not have the lounge area that the buses boasted, but were equipped with a full donut kitchen and PA system. ${ }^{16}$ Cinemobiles were another Red Cross innovation of World War II. An observer recalled, "A rolling theater, built on the chassis of a one-and-one-half-ton General Motors truck, the cinemobile was complete with sound projections, portable screens and films, a portable stage, small piano, and public address system." ${ }^{17}$ Cinemobiles were quite popular with GIs, as they not only screened films but also put on shows that encouraged soldiers' active participation.

Clubmobiles were staffed exclusively by women. One former clubmobiler noted that in 1999, "Red Cross National Headquarters is still not sure how many women volunteered for overseas duty [during World War II]. Documents list every penny spent on supplies and services to the troops during the war, and state that over 15,500 ARC volunteers served abroad," of which between 12,000 and 13,500 were women. ${ }^{18}$ According to the official clubmobile newspaper, there were approximately 580 clubmobilers serving in the ETO in August 1944, with 400 of these on the Continent. ${ }^{19}$ However, these numbers were constantly changing as new women

\footnotetext{
${ }^{14}$ Morgan, The Clubmobile, 45. The groups were lettered A-H, K, L, likely skipping I and $\mathrm{J}$ to avoid confusion.

${ }^{15}$ Korson, At His Side, 280, and United States Army, Report of Operations (Final After Action Report): $12^{\text {th }}$ Army Group, vol. 2 (1945), 20, https://babel.hathitrust.org/cgi/pt?id=mdp.39015051394743\&view=1 up\&seq=26.

${ }_{17}^{16}$ Morgan, The Clubmobile, 45-6.

${ }^{17}$ Korson, At His Side, 287.

${ }^{18}$ Norwalk, Dearest Ones, $\mathrm{x}$.

19 "Fifty-Three Girls Arrive from the States," Sinker, Aug. 4, 1944.
} 
joined, veterans returned home, and women were transferred between the various departments of the Red Cross (service clubs, clubmobiles, entertainment, etc.). Even the clubmobilers' own record of their service does not include exact figures on the number of women who served. ${ }^{20}$

While the original bus crews included a locally recruited male driver, the women drove their own vehicles throughout Western Europe. Each three-woman clubmobile crew had a designated captain, responsible for organizing crew operations and handling official paperwork. Though she received a slight raise, the title of "captain" was, as Gretchen Schuyler told her family, "only for official letters from Hqts. It sounds good, and is an honor, I suppose, but that is as far as it goes. We are not military, you know." ${ }^{21}$ All clubmobilers were accorded the rank of second lieutenant if captured, regardless of their title. ${ }^{22}$

Each of the ten groups sent to the Continent- "Zone V"- in the summer of 1944 included a group captain, "24 Clubmobile operators [ 8 crews], two song-and-dance specialists on the Cinemobile, and four supply truck drivers who filled in as spare crew when girls were away on leave or were ill," Angela “Angie" Petesch recalled. ${ }^{23}$ Though the female group captain was in charge of the group's activities, she was initially overseen by a man who organized the itinerary. ${ }^{24}$ Indeed, while there were some women in the clubmobile administration, Virginia Cook recalled, "we were always titled 'Assistant Personnel Division,' 'Assistant Clubmobile

\footnotetext{
${ }^{20}$ Though The Clubmobile contains a list of names and mailing addresses for all active and inactive clubmobile personnel dated August 30,1945, this list contains several inaccuracies and does not specify the source of the information; thus, I have not considered it a full list of clubmobilers. Morgan, The Clubmobile, 183-200.

${ }^{21}$ Gretchen Schuyler to "Katie and all the rest," 8 January 1944, Box 1, Folder 1944 [1], Papers of Gretchen Schuyler. Throughout their correspondence, many of the women frequently used abbreviations, from the "+" sign to connote "and" to such shortenings as "HQ" or "Hqts." and "RC" or "ARC" ([American] Red Cross). I have maintained such abbreviations whenever possible when quoting directly from letters. Additionally, several women, including Gretchen Schuyler and Mary Small, addressed their letters to "family" or other similarly vague groups. Due to the lack of envelopes, I have listed addressees in these cases as "family," "everyone," etc.

${ }^{22}$ Regulations stated that all personnel below male Assistant Field Directors would have the assimilated rank of second lieutenant. Assistant Field Directors and above were given the rank of captain. This meant, in effect, that all Red Cross women carried the same assimilated rank. "Certificates of Identification for Non-Combatant Civilians and Protected Personnel," 28 April 1944, Virginia Storts Hall, Box 2, Folder 10, Clubmobile Service Collection.

${ }^{23}$ Petesch, War Through the Hole of a Donut, viii.

${ }^{24}$ Korson, At His Side, 274, 280, and “Zone V Plans," Sinker, June 9, 1944.
} 
Department' - there was always a man as Director (most of whom contributed very little!)."25

Each clubmobile group also had two soldiers attached to it "who ran the two huge generators which provided the electricity for the doughnut machines," as noted in an overview of Group F's operations. ${ }^{26}$ The group's assigned GIs came under the authority of the female group captain, and there are few references to these soldiers in clubmobilers' letters and memoirs; most mentions are part of an overview of a group's (original) composition.

Clubmobilers proved quite capable of taking care of themselves, without male oversight. Group F Captain Gretchen Schuyler told her family in early June 1944, “Mr. Corneli hasn’t as yet joined our unit to take over the Supervisor's work, so during this interval I have done both my job as Group Captain and also his." ${ }^{27}$ Though Gretchen looked forward to the reduction in stress that Corneli's arrival would bring, she performed his duties well. In fact, Group F "received [a] commendation from our Divisional General of the Airborne, and [sic] also from Mr. Gibson,A.R.C. [sic]” while under Gretchen's supervision. She confided to her family, "I just hope that with a man in charge things will go just as well." ${ }^{28}$ Gretchen had reason to worry: when Corneli arrived, she reported, “This man knows absolutely nothing about Clubmobiles and I must teach him. I'm in no mood for that at this late date!" 29 With a capable and experienced teacher like Gretchen, Corneli soon learned to be an adequate replacement.

Group H's male supervisor, on the other hand, was fired before they had even crossed the Channel, to be replaced by Group Captain Eva Christensen, who, like Gretchen, had been doing

\footnotetext{
${ }^{25}$ Virginia Wilson (Cook) Osgood to Anne Engelhart, Associate Curator of Manuscripts, Arthur \& Elizabeth Schlesinger Library on the History of Women in America, Radcliffe College, 5 July 1995, Virginia Wilson Cook Osgood, Box 11, Folder 1, Clubmobile Service Collection.

${ }^{26}$ Schuyler, "Operational Outline History of the American Red Cross Clubmobile Group 'F'," 1.

${ }^{27}$ Gretchen Schuyler to Aunt Ede, 11 June 1944, Box 1, Folder 1944 [2], Papers of Gretchen Schuyler.

${ }^{28}$ Gretchen Schuyler to "Katie and all the rest," 19 June 1944, Box 1, Folder 1944 [2], Papers of Gretchen Schuyler.

${ }^{29}$ Gretchen Schuyler to Mrs. C.J. McCarthy (sister Katie), 20 June 1944, Box 1, Folder 1944 [2], Papers of Gretchen Schuyler.
} 
his job anyway. ${ }^{30}$ However, upon Group H's arrival in France, Eva noted that the Red Cross "felt it was inappropriate for a girl to handle this convoy through France in search of a charging Army so they were lending me a Mr. Davis who was the supervisor for Group G." Assuming that the women were unorganized without a man in charge, Davis wanted all the clubmobiles completely re-packed; Eva flatly refused. Davis then requested that the tires be refilled. When the air compressor broke, he announced that the group would have to delay its departure while they awaited new equipment; however, Eva remembered, "The girls, undaunted, pulled out their hand pumps and pumped away, and got all the tires filled. Mr. Davis gave up. He had completely underestimated our girls. ${ }^{.31}$ Indeed, all male supervisors were recalled or reassigned a month or so after the women had landed on the Continent. When this happened to Group F in midSeptember, Gretchen wrote, "I am now in full charge of this outfit [...] I was worried when Clif [Corneli] was recalled. Now I am wondering just what he did when he was here!"32

\section{A day in the life of a clubmobiler}

Clubmobile work consisted of long days and physical labor; Red Cross records show that “253,982,600 doughnuts were served from clubmobiles and canteens in overseas theaters during 2 years, 1944-1946."33 The clubmobile newspaper reported that between November 1942, when the first clubmobile rolled into action, and February 1945, "Clubmobile girls alone made

\footnotetext{
${ }^{30}$ Johnson, I Too Shall Wear Purple, 196-7.

${ }^{31}$ Johnson, I Too Shall Wear Purple, 199-202.

${ }^{32}$ Gretchen Schuyler to Mrs. C.J. McCarthy, 18 September 1944, Box 1, Folder 1944 [3], Papers of Gretchen Schuyler. Following these reassignments, male Red Cross officials were far removed from the day-to-day running of clubmobiles. The male Field Director, the lowest-ranking man in the clubmobile organization, was the equivalent of the general of an Army Group (such as Gen. Omar Bradley, commander of the $12^{\text {th }}$ Army Group). Female Clubmobile Supervisors, who oversaw several clubmobile groups, were comparable in authority to Gen. George S. Patton, Jr., in command of the $3^{\text {rd }}$ Army. Clubmobile Group Captains (also female) were a step below Supervisors, at the level of a general commanding a specific corps of the army. Schuyler, "Operational Outline History of the American Red Cross Clubmobile Group 'F,"” 4.

${ }^{33}$ American National Red Cross, Red cross service record, 40.
} 
43,364,049 doughnuts. ${ }^{34}$ During their busiest week, Group F served 34,575 cups of coffee and 80,100 donuts. ${ }^{35}$ These figures speak volumes about the women's efforts. One clubmobiler warned newcomers, "You work harder than 90 per cent of the men in the Army.",36

Though each clubmobile was fully equipped for mobile donut making, the women quickly discovered that unpredictable field conditions meant there was no guarantee that they would be able to plug in their generators, nor that they would even be on solid ground. As such, (Jane) Anne Jack explained, "the usual set-up [was] with one truck cooking all day while the others did the serving and two or more trucks cooked in the evening to get a head start on the next day. ${ }^{, 37}$ While on the Continent, many crews hired locals and refugees to make donuts for them. When they did cook their own donuts in their initial months on the Continent, it meant a hard day's work; the clubmobile newspaper described, "we get up at five in the morning, having to make some 3,200 doughnuts and 160 gallons of coffee, ready to serve at two on the dot. We know 3,200 doughnuts mean 160 pounds of flour or eight batches. It will take eight batches nearly eight hours to do; add an hour for the machine to heat and an hour to clean up, with time off (if possible) for breakfast and lunch." ${ }^{38}$ A Chicago Sun reporter recognized that clubmobilers "work 16 hours a day, seven days a week, and they work like longshoremen." 39

The production of this volume of coffee and donuts required detailed estimates and hard physical work. When planning clubmobile services on the Continent, Red Cross officials estimated that "one Clubmobile could supply 150 men per hour with two doughnuts each. [...] Then this was translated into flour and fat needs for 15 days and produced such figures as

\footnotetext{
34 “Chow Hounds Par Excellence," Sinker, Apr. 6, 1945.

35 "Clubmobile Group F...Weekly Output of Coffee and Doughnuts on the Continent," Box 2, Folder “\#73 Weekly Output Coffee \& donuts (8-12-44 5-12-45," Papers of Gretchen Schuyler.

${ }^{36}$ Morgan, The Clubmobile, 120.

${ }^{37}$ Anne Jack, "Group E's History," 14, Jane Anne McKee Jack, Box 4, Folder 1, Clubmobile Service Collection.

38 "Everyone Who is in Red Cross Work Over Here," Sinker, Dec. 8, 1944.

${ }^{39}$ W.A.S. Douglas, “Antidote for Homesickness," Chicago Sun, date unknown, Box 1, Folder 1944 [3], Papers of Gretchen Schuyler.
} 
$300,000 \mathrm{lbs}$. of flour and 100,000 lbs. of fat and 2,250,000 men made happy with two doughnuts each and 320 smiles!" ${ }^{40}$ To make the men happy, the women carried heavy coffee urns and flour sacks, wrestled massive globs of dough in the cramped quarters of the clubmobile, and cleaned the entire truck each day, in addition to hundreds of coffee cups. But clubmobiling was far more than just coffee and donuts. It was also serving with a smile, answering the same questions and laughing at the same jokes all day long, and even dancing. One clubmobiler remembered, "You smile and talk all day, [...] Dance in the snow and mush and on ice, dance with the rain falling or the sleet, or in ruined old stables or in cellars or mess kitchens or on the Clubmobile among the coffee urns, donuts and people [...] until your feet are worn down to the knees." ${ }^{41}$

Clubmobilers on the Continent quickly learned to improvise, for equipment malfunctions and unpredictability were common. Oftentimes, Mary Small complained, "the darn generator broke down," or, as the clubmobile newspaper wittily noted, "They tell us we're serving two hundred/Instead we find five hundred men/And each has a friend in the barracks—-So what are we gonna do then?" "42 Group F's captain complained that the schedule "is good for about ten minutes! I spend hours each day trying to juggle the cussed thing, and trying to serve more men with less vehicles. Sickness, vehicle maintenance, transfers, weather, generator troubles, etc. all have to be considered." ${ }^{43}$ Such challenges were an accepted part of clubmobile life.

\section{"[N]o teacher can ever tell you"}

Clubmobiles were staffed exclusively by women, but not just any woman would do. ${ }^{44}$

Scholar Claudia Hagen notes, "The women had to know the right slang, have an appealing look,

\footnotetext{
${ }^{40}$ Morgan, The Clubmobile, 46.

${ }^{41}$ Morgan, The Clubmobile, 120.

${ }^{42}$ Mary Churchill Small to "family," 18 March 1945, Folder "MCS Letters from Europe [2]," Papers of Mary Churchill Small, and "Sinker Serenade," Sinker, Feb. 2, 1945.

${ }^{43}$ Gretchen Schuyler to "family," 15 November 1944, Box 1, Folder 1944 [3], Papers of Gretchen Schuyler.

${ }^{44}$ Section title: Morgan, The Clubmobile, 120.
} 
a sympathetic heart, a sense of humor, be sociable and entertaining, know how to deflect unwanted advances, get a laugh at bawdy jokes or songs." 45 Many of these essentials would be learned on the job, but the Red Cross also set up hiring guidelines to find women suited for the task. These requirements served to ensure that the organization could provide the best possible morale services to the troops, with little concern for the women themselves.

Historian Kara Dixon Vuic asserts that ultimately, the Red Cross wanted "pretty girls who liked servicemen" to serve as clubmobilers, who were classified as staff assistants. ${ }^{46}$ However, physical heartiness was also essential; Gretchen Schuyler told her father, "Thank God I was born with the strength of an ox!It [sic] is a necessary atribute [sic] over here." ${ }^{47}$ The Red Cross described "an 'average' Red Cross girl [...as]: Blue eyes, brown hair, 5' 5", approximately 127 pounds, twenty-eight years old, and a teacher in civilian life." However, few clubmobilers met this description, and they ridiculed the idea that they could be so easily described. ${ }^{48}$

Though not an official requirement, the majority of clubmobilers were single, and thus more willing to serve overseas for years at a time. Most married clubmobilers had husbands in the military, and the Red Cross required that they have no children under eighteen. ${ }^{49}$ The Red Cross stipulated that any woman who married while overseas would be transferred to a different theater, away from her husband. Mary Lou(ise) Pearce commented of this regulation, "the ARC expects all individuals to give their undivided attention to the tasks that they have been sent over

\footnotetext{
${ }^{45}$ Hagen, American Women During World War II, 211.

${ }^{46}$ Vuic, The Girls Next Door, 73, and Lora Kelly, "Red Cross Clubmobiles Abroad," The Red Cross Courier 27, no. 10 (April 1943): 11, https://babel.hathitrust.org/cgi/pt?id=umn.31951002790942e;view=1 up;seq=693.

${ }^{47}$ Gretchen Schuyler to Col. Philip Lansing Schuyler (father), 12 December 1943, Box 1, Folder 1943 [2], Papers of Gretchen Schuyler.

48 "HQ Communiques," Sinker, Sept. 1, 1944.

${ }^{49}$ Vuic, The Girls Next Door, 72.
} 
for - and to perform the tasks to the best of their ability." ${ }^{50}$ The Red Cross would, if necessary, take steps to prevent a woman's personal life from interfering with her work.

As Vuic notes, the Red Cross preferred "college graduates with a degree in recreation, social welfare, or education," but this was not essential; hiring guidelines stated, "In exceptional instances outstanding experience in recreation may be considered as a substitute for college graduation. ${ }^{51}$ Much was left to the interviewer's discretion, and Vuic highlights that some prioritized "a pleasing personality over professional preparation." ${ }^{, 52}$ While an outgoing personality was essential to keeping soldiers' morale high, experience or training in social work or education could give a candidate some preparation for the challenges of clubmobile life. Jane Phillips told her parents, "I think the little bit of case work I did helped me more for this kind of work than anything I ever did. ${ }^{, 53}$ Though she also acknowledged the importance of personality, Jane believed it was no substitute for experience. Unfortunately, Red Cross officials did not always agree. Another clubmobiler recalled, "I knew nothing of social welfare and was vastly relieved when I realized that most of my group were equally ignorant." ${ }^{.54}$ This shared ignorance meant that clubmobilers would learn together how to deal with the stresses of war.

Though the Red Cross sought women with a "youthful hospitality and friendliness," Vuic argues that they needed to be "mature enough to "correctly gauge and cope with the complications and temptations of the unnatural life on an Army post, where...they are courted

\footnotetext{
${ }^{50}$ Mary Louise Pearce Hart, "This is the Way it Was: A World War II Love Story," 19, Mary Lou Pearce Hart, Box 3, Folder 9, Clubmobile Service Collection.

${ }^{51}$ Vuic, The Girls Next Door, 72, and "American Red Cross Employment Opportunities (Abridged)," Virginia Storts Hall, Box 2, Folder 10, Clubmobile Service Collection.

${ }^{52}$ Vuic, The Girls Next Door, 73.

${ }^{53}$ Jane Weir Phillips to Mr. \& Mrs. Arthur L. Weir (parents), 20 March 1944, Jane Weir Phillips Scott, Box 11, Folder 8, Clubmobile Service Collection.

${ }^{54}$ Nathalie Chadwick, "Beyond the Lightline," 14, Nathalie Fallon Chadwick, Box 1, Folder 8, Clubmobile Service Collection.
} 
and pursued nightly by thousands of eager, sex-starved men." ${ }^{, 55}$ In keeping with its focus on maintaining soldiers' morality in addition to their morale, the Red Cross tried to ensure that its workers would serve as big sisters or platonic friends to soldiers. While the hiring of only "mature" women likely allowed them to better adapt to the unpredictability of military life, this was merely a byproduct of the Red Cross' concern with soldiers' morality. "Maturity" was subjective because age guidelines were treated as a suggestion rather than a requirement; though the minimum age for a staff assistant was 25 , younger women were often hired. ${ }^{56}$

The majority of clubmobilers were from the (upper) middle class, drawn from the relatively small pool of women who had gone to college in the late 1930s and early 1940s. Their class and education, however, did little to prepare them for the conditions of clubmobile life, as a reporter noted: "Ninety per cent of them college graduates, and all scrubbing for dear life like [...] washerwomen [...] Before they joined the Red Cross many of these girls had had somebody to do this sort of chore for them." ${ }^{57}$ While their education and relative maturity helped some cope with the emotional challenges of their job, many commented on how overqualified, and yet unprepared, clubmobilers seemed. Unsurprisingly, some women felt underappreciated.

Describing a friend's resignation from the Red Cross, Mary Small explained, "she would not have turned her back on the war had she felt that Red Cross was really using her to the extent of her capabilities. It's a complaint almost all of us have, I suppose. It's simply incredible the backgrounds and abilities which have been turned to the making of doughnuts and the carryingon of a nondescript line of chatter." 58 Though this description does clubmobile work a disservice,

\footnotetext{
55 “American Red Cross Employment Opportunities (Abridged)," and Vuic, The Girls Next Door, 76-7.

${ }^{56}$ Vuic, The Girls Next Door, 75. Mary Small, for example, celebrated her $25^{\text {th }}$ birthday in Germany in April 1945. Mary Churchill Small to "everyone," 21 April 1945, Folder "MCS Letters from Europe [2]," Papers of Mary Churchill Small.

${ }^{57}$ Douglas, "Antidote for Homesickness."

${ }^{58}$ Mary Churchill Small to "family," 8 December [1944], Folder "MCS Letters from Europe [1]," Papers of Mary Churchill Small.
} 
it is somewhat accurate. Anyone could be trained to make coffee and donuts; indeed, many crews hired locals to cook for them. While their education helped many clubmobilers adjust to their new lives, the Red Cross ultimately cared little about the women's individual skills or talents. Ironically, the Red Cross ignored the individuality of its female workers even as it recognized that their greatest asset was the ability to make each soldier feel like an individual.

Before being shipped overseas, clubmobile women attended Red Cross training at American University in Washington, D.C., initially for six weeks; as the war progressed and the need for volunteers increased, this became two. ${ }^{59}$ Betty Jane "B.J." Thomas remembered that the women learned to lead recreational activities and "gleefully threw off the 'correct upbringing' that was part of our past" to become comfortable initiating a conversation with soldiers. ${ }^{60}$ However, scholar James H. Madison notes that many women later felt that their training provided "insufficient preparation [for] the emotional and cultural challenge of overseas work."61

Significantly, the training program at American University was for all Red Cross women, regardless of theater or assignment. In fact, most women did not know where they were being sent until they received their travel orders only a day or so before departing. One reporter noted with surprising insight, "The only thing she can be sure of is that she will have to meet one crisis after another." ${ }^{\prime 62}$ Chichi Metcalfe recalled, "Of the 134 girls in our class, some were assigned to hospital service, some to camp service, and forty-two to club overseas service." ${ }^{63}$ Even "club overseas service" could mean either a stationary service club or a clubmobile. If assigned to a clubmobile, the women received some additional training in clubmobile operation, and later on driving and equipment maintenance before being sent to the Continent.

\footnotetext{
${ }^{59}$ Hagen, American Women During World War II, 211.

${ }^{60}$ Olewiler, A Woman in a Man's War, 33.

${ }^{61}$ Madison, Slinging Doughnuts for the Boys, 15.

${ }^{62}$ Vernon Pope, "GI Joe's Best Girl," Aug. 20, 1944, unlabeled folder, Papers of Mary Churchill Small.

${ }^{63}$ Rexford, Battlestars \& Doughnuts, 4.
} 
However, clubmobilers like Elma Ernst discovered that when they got into the field, "We were all like sore thumbs trying to apply text book knowledge to reality." ${ }^{\text {"64 }}$ Their training stated, for example, that when making donuts, "For every five pounds of [donut] flour, you use two pounds, three ounces of water." The women were expected to weigh the water to ensure that their proportions were accurate. But, as the clubmobile newspaper editorialized, "Frankly, we feel the above procedure is a little bit whacky, due to its impracticability. The best thing to doand we may get fired for saying so - is to weigh the correct amount, put it into your large, metal pitcher, and mark where the water comes. Then, each time, just fill the can to your marker."65 This was a far easier, and more practical, solution for making the fifteen- to twenty-pound batches of dough the women regularly produced.

The Red Cross was not entirely ignorant of the challenges its workers would face. Elma recalled that part of her "indoctrination" into Red Cross service consisted of "long periods of interrogation: 'Do you think you can maintain a friendly, but impersonal relationship with the many men with whom you will be constantly in contact?' 'Do you think you can endure long hardships, perhaps deprivations, close to combat areas?' 'Can you face blood and death?'—and so on. Obviously, I answered affirmatively." ${ }^{, 66}$ Significantly, Elma’s answers were based entirely on her own self-evaluation. She states that "obviously," she said she could do what was required - and indeed, what woman determined to serve her country would answer "no" and jeopardize her chance? The Red Cross' evaluation of its recruits was certainly not comprehensive, and did nothing to prepare them for what they would face. In terms of training, they were less prepared than the men they were to support.

\footnotetext{
${ }^{64}$ Elma Ernst Fay, “Through a Donut Hole,” Chapter 1, Elma Ernst Fay, Box 2, Folder 6, Clubmobile Service Collection.

65 "How to Make Doughnuts (?)," Sinker, Nov. 10, 1944.

${ }^{66}$ Fay, "Through a Donut Hole," foreword.
} 
However, despite this lack of training and the rather haphazard selection process, most clubmobile women adapted remarkably well to life in a war zone. Ultimately, their experiences, both individual and collective, were the most valuable training they would receive. New arrivals could look to veteran clubmobilers for advice, and veterans relied on one another's support and wisdom in facing new challenges. Indeed, one member of Group E believed that what made them successful simply could not be taught: "What we bring to a job [...is] in ourselves; and, if we don't have it somewhere implicit within us, we'll never have it." Clubmobilers, she continued, would "learn how to wheel a $6 \times 6$ and how to make donuts, and anybody can do that. But when you can give and what you can afford to lose, no teacher can ever tell you.” Anyone could learn these basic skills, but to be able to "smile when you're dying" and "hear the same old things with a fresh, listening face," took a certain amount of personality and discipline that only experience could teach. ${ }^{67}$ As such, clubmobilers relied on one another and drew strength from their shared experiences as they adapted to the environment of war and their own role in it.

\section{"Leaves were necessary from time to time, just to keep going"}

Arguably the only way Red Cross headquarters acknowledged the difficulty of its workers' lives was the allocation of leave, which was intended to surpass military policy. ${ }^{68}$ While soldiers during World War II could be granted leave at a rest camp, leave was not a guarantee for every US soldier until the Korean War. ${ }^{69}$ Red Cross workers, however, were supposed to be allocated a remarkable amount of leave, as Mary Small explained to her family: "you must be wondering what the score is - two leaves in such rapid succession [...] The four days came as a result of saving up the week-end ( 2 days), to which we are entitled each month,

\footnotetext{
${ }^{67}$ Morgan, The Clubmobile, 120.

${ }^{68}$ Section title: Rexford, Battlestars \& Doughnuts, 104.

${ }^{69}$ Kindsvatter, American Soldiers, 94, 99.
} 
for 2 months. The week is what we are supposed to have at the end of every four months." ${ }^{.70}$ This policy was the Red Cross' only recognition of the difficulty of the women's work.

The rather magnanimous leave policy was an attempt to keep workers healthy, as Mary noted in December 1944: "It seems that after landing all their personnel in the hospital last winter, the Red Cross is trying to forestall the same thing this winter." ${ }^{, 71}$ Historian Kara Dixon Vuic confirms that these leave regulations were established only after the Red Cross discovered the dangers of failing to provide its women with a respite from their work: "After one woman experienced a breakdown, a Red Cross regional club supervisor warned that the organization needed to 'take particular care of girls operating under trying conditions $[\ldots]$ ' The $[\ldots]$ mental strain of forming friendships with [soldiers] who did not return from missions exacted a high cost. Given the nature of their work, he recommended that the women take periodic leaves., ${ }^{72}$ Though allowing its workers frequent leave was intended to help the women by temporarily removing them from the stresses of their job, this solution alone was inadequate, especially for clubmobilers.

Due to the nature of their assignments, it was more difficult for clubmobile women to take leave while on the Continent. If they remained with their group on days off, they were still subject to military orders. As such, Mary's "third day of 'leave' was celebrated by 5 o'clock rising, packing and loading, getting the trucks checked, making a six-hour convoy trip in the pouring rain, unloading again and settling in here." ${ }^{, 73}$ Though the Red Cross allocated leave, the women often did not get to use it, due to the needs and regulations of the military they were there to serve. Before crossing the Channel in the summer of 1944, Anne Jack complained that she,

\footnotetext{
${ }^{70}$ Mary Churchill Small to "family," 8 December [1944].

${ }^{71}$ Mary Churchill Small to "family," 8 December [1944].

${ }^{72}$ Vuic, The Girls Next Door, 111.

${ }^{73}$ Mary Churchill Small to "family," 2 April 1945, Folder "MCS Letters from Europe [2]," Papers of Mary Churchill Small.
} 
like many others, was "leaving without the week's leave that everybody's supposed to get."74 For several months in the late summer and fall of 1944, clubmobilers could not take leave at all. ${ }^{75}$ This restriction kept the women working hard with no hope of a rest; one clubmobiler complained, "We haven't had a day off in ages,and [sic] each day is a 14 hour one, at least!",76 Despite official restrictions, some clubmobilers recognized the importance of a break from their work and organized days off to the best of their ability. Gretchen Schuyler, captain of Group F, was particularly sensitive to the necessity of periodic breaks and organized a rest period for Group F during the fall of 1944: "We have just had a two-day rest. Leaves are taboo at the moment. So I restricted the gals to the camp area,and [sic] had a rest. They sure needed one too." ${ }^{, 77}$ Even when it made scheduling difficult, Gretchen worked hard to ensure that her group received time off: "Right now I am up to my ears trying to arrange a weeks [sic] leave and some transportation for all my Group. It is a mad house. But I do want to be sure they get their time-off [...] We have been over here over the four month period,and [sic] we all have a week due us."78 Her diligence in allowing her group members time to rest paid off that winter. She reported, "My Group has lost less people than any other through sickness or overwork. But from the start I have insisted upon them having their time-off. I guess it is paying dividends now."79

Thrust into the environment of war with minimal training, clubmobilers were forced to adapt to unpredictable conditions with little guidance from Red Cross officials. Headquarters' one morale-boosting policy, the allocation of leave, was inconsistent because both the Red Cross and the military continued to prioritize service to the men above clubmobilers' well-being by

\footnotetext{
${ }^{74}$ Jane Anne Jack to George Jack (husband), 20 July 1944, Jane Anne McKee Jack, Box 6, Folder 8, Clubmobile Service Collection.

${ }^{75}$ Gretchen Schuyler to Aunt Ede, 12 October 1944, Box 1, Folder 1944 [3], Papers of Gretchen Schuyler.

${ }^{76}$ Gretchen Schuyler to "family," 16 September 1944, Box 1, Folder 1944 [3], Papers of Gretchen Schuyler.

77 Gretchen Schuyler to "family," 4 October 1944, Box 1, Folder 1944 [3], Papers of Gretchen Schuyler.

${ }^{78}$ Gretchen Schuyler to "Katie and all the rest," 5 December 1944, Box 1, Folder 1944 [3], Papers of Gretchen Schuyler.

79 Gretchen Schuyler to "family," 15 November 1944.
} 
imposing limitations on leave. The shortcomings of this policy were a symptom of the Red Cross' broader failure to recognize the needs of its female workers and its overwhelming concern with service to male troops. Ironically, the Red Cross' failure to anticipate what clubmobilers would face overseas forced them to rely on women's knowledge and experience in the field, undermining the gender roles that they strove to uphold in the creation of the clubmobile position.

Despite the fact that hiring guidelines privileged college education, especially in fields like education that might provide some background for the type of work the women were doing, many clubmobilers did not meet these criteria, but were hired based on personality or appearance. As such, they were even less prepared for the emotional challenges of clubmobile life, compounding the difficulties caused by their lack of training. The Red Cross' description of their clubmobilers as a homogenous group of women similarly indicated their lack of regard for the women's needs, portraying them not as individuals but as interchangeable members of a group. More problematically, the Red Cross not only ignored but was unaware of many of the women's needs and day-to-day struggles. Limited training and official ignorance meant that clubmobilers were forced to adapt to the challenges of life on the Continent with only one another for support or advice. These challenges included not only issues of the successful operation of a clubmobile, but, more fundamentally, of living in an active war zone. Clubmobilers near the front lines had to learn quickly how to survive amidst violence and near-constant danger. 


\section{Chapter 2: A "forward element in the war against Germany": Clubmobilers on the front lines}

"In a little town East of the border in Germany, one could find in the early part of October, 1944, a group of 29 women busily cooking doughnuts under a barrage of artillery. You could see them when the air cleared of falling shrapnel and the mist of bomb burstings let up a bit. Between doughnut batches, they would grab their helmets and run for a hole." ${ }^{\prime 1}$ Thus begins the tale of Group D, as recounted in The Clubmobile-The ARC in the Storm, the clubmobilers' own account of the war. This vignette perfectly encapsulates the women's experiences; as Nathalie Fallon recalled, "the girls soon found they faced actual combat conditions." ${ }^{2}$ However, they were always expected to place the soldiers' well-being over their own.

Despite the commonly held belief that women had no place in a combat zone, clubmobilers lived and worked just behind the front lines for months. Following the army so closely, clubmobile women were often in far more dangerous situations than the Red Cross wanted to admit. Despite the public perception, noted by historian James H. Madison, that "Red Cross service seemed less troubling" than military service, the Red Cross offered female volunteers greater opportunities to serve overseas and, ultimately, face the dangers and realities of war. ${ }^{3}$ Though WACs served in all theaters of war, they were assigned clerical jobs that kept them far behind the front lines, while the Navy's WAVES were banned from overseas duty outside the Western Hemisphere. ${ }^{4}$ Indeed, several clubmobilers considered service in the WACs, WAVES, or even the Marines' Women Reservists, but ultimately chose the Red Cross because

\footnotetext{
${ }^{1}$ Chapter title: Ellie Green, "Journal," 41, Nancy Bastien Chase, Box 1, Folder 11, Clubmobile Service Collection. Morgan, The Clubmobile, 134.

${ }^{2}$ Chadwick, "Beyond the Lightline," foreword.

${ }^{3}$ Madison, Slinging Doughnuts for the Boys, 10.

${ }^{4}$ Leisa D. Meyer, introduction to Mollie's War: The Letters of a World War II WAC in Europe, Mollie Weinstein Schaffer and Cyndee Schaffer (Jefferson, NC: McFarland \& Company, Inc., 2010), 7-8, and Weatherford, American Women and World War II, 80.
} 
they wanted to serve overseas. ${ }^{5}$ Like the women's contemporaries, historians have largely ignored the risks that clubmobilers faced by focusing on female military corps when examining women's wartime service.

This chapter will demonstrate that although clubmobilers were noncombatants, the realities of working in the war zone shaped their experiences. They pitched tents in the muddy fields of France, dove into foxholes under shellfire, and were greeted by grateful French and hostile German civilians. Clubmobile groups' vehicles and living quarters were destroyed, and some clubmobilers were injured or killed as a result of their service. Ultimately, clubmobilers experienced the war's violence and destruction alongside the men they served. However, their gendered noncombatant status has obscured this reality.

\section{"[M]ore freedom than many soldiers"}

At General Eisenhower's request, "Clubmobile service [would] be made available to the invasion forces as soon after the initial landing as would be tactically possible." Angela "Angie" Petesch recalled, "the Clubmobiles' directive was 'to follow as close in the wake of the armed forces as military authorities would permit,", and they took this to heart. ${ }^{7}$ Shelling, snipers, and "bed check Charlie" quickly became second nature to many clubmobile women, who adapted to the environment of war and learned to thrive amidst its uncertainty and dangers.

True to their directive, clubmobiles arrived on the Continent soon after the invasion forces. Group B was the first to go ashore, landing on Utah Beach on July 16, 1944, little more a

\footnotetext{
${ }^{5}$ Gretchen Schuyler chose the Red Cross over the Army "because they [the Red Cross] guaranteed overseas duty." B.J. Thomas "discovered [the WACs, WAVES, and SPARS] could give no guarantee, in fact little possibility, of getting overseas." Not wanting to be stuck behind a desk in the US, she volunteered instead for Red Cross service. Bettie Walters initially considered serving in the Marines, but ultimately chose the Red Cross. Michael J. Bailey, "Gretchen Schuyler, Athlete, Captain in Red Cross; At 91," Obituaries, Boston Globe, Dec. 24, 2002, Box 1, not in folder, Papers of Gretchen Schuyler; Olewiler, A Woman in a Man's War, 23-4; and Elizabeth "Bettie" Walters to Mr. and Mrs. Aaron Walters, 2 undated letters from April/May 1943, Walters Family Collection.

${ }^{6}$ Section title: Korson, At His Side, 280. Morgan, The Clubmobile, 45.

${ }^{7}$ Petesch, War Through the Hole of a Donut, 114.
} 
month after the D-Day landings. By August 18, all ten clubmobile groups had landed on either Utah or Omaha Beach. They quickly spread throughout France and the surrounding countries; indeed, clubmobilers could be found almost everywhere American troops were stationed.

Throughout the latter half of 1944, most clubmobile groups were based in France, Belgium, or Luxembourg, though Group D arrived in Germany in mid-September. In the spring of 1945, clubmobiles followed the army's advance through Germany, where most celebrated VE Day. ${ }^{8}$

From the moment they disembarked on the beaches of northern France, clubmobilers faced the dangers of living in an active war zone. On the night they landed, Group F was led to their bivouac area in total darkness. In the morning, one member reported, "We learned that the roads we had so cautiously traversed the night before were mined and that one car of French officers had struck a mine and all were killed." ${ }^{9}$ This was merely the beginning of the dangers and violence that the women would be exposed to. Whether "within a few miles of the front" or "actually at the front serving the troops of an infantry division," Eloise "Ellie" Green observed that clubmobilers often "became a forward element in the war against Germany.",10

Red Cross officials had little understanding of the dangers the women would face. The gas masks issued to each clubmobiler were rarely used, while the shiny gray paint on the new clubmobiles equipped for the Continent posed problems. As Elma Ernst recalled, "Immediately [after] we landed on the Continent, the Army began complaining about our 'visible for miles' buggies. [...] So, one by one, the clubmobiles were painted olive drab."11 This camouflage

\footnotetext{
${ }^{8}$ With the exception of a section of Group G in Austria and the entirety of Group B, which was in Czechoslovakia, putting it farther east than any other clubmobile group, to my knowledge. See Appendix II for a list of all ten clubmobile groups, their dates of landing, and their positions on VE Day.

9 "Doughgirl's Diary...," Vilas County News-Review (Eagle River, WI), date unknown, Nancy Bastien Chase, Box 1, Folder 11, Clubmobile Service Collection.

${ }^{10}$ Anne Ferguson Boy, "The Experiences of One American Red Cross Clubmobiler July 1943 to August 1945," 128, 151, Anne Ferguson Boy, Box 1, Folder 2, Clubmobile Service Collection, and Green, "Journal," 41.

${ }^{11}$ Schuyler, "Operational Outline History of the American Red Cross Clubmobile Group 'F,"” 2, and Fay, "Through a Donut Hole," Chapter 15.
} 
would come in handy as the vehicles were driven ever closer to the front lines. Gretchen

Schuyler told her family airily, "My jeep [...] used to be gray. Now it is O.D. with a star and circle on the hood, so I won't get sniped at. (I hope that will solve that little problem!)"12 Though Gretchen's cavalier tone was likely intended to reassure her family, her comments underline that such dangers were commonplace. These accounts also demonstrate that the Red Cross had given little thought to the conditions the women would face on the Continent, leaving them to address the impracticality of their equipment themselves. Despite their lack of preparation, most clubmobilers quickly adapted to life in a war zone. Group K's Nathalie Fallon explained, “As we move along with Corps, we become experts in our own ways. Camouflaging the trucks each night, digging our slit trenches, and learning to bargain for eggs or potatoes with a handful of cigarettes. ${ }^{, 13}$ Like soldiers, clubmobile women pitched tents and dug latrines in the muddy fields of France, with only a helmet to help them bathe.

Clubmobilers, Elma Ernst recalled, were "supposed to maintain certain safe boundaries from the Front," but in practice, this was not the case. ${ }^{14}$ The rapidly changing military conditions made it difficult to keep them at a "safe distance" from the action, and no amount of "safe boundaries" could protect the women from mines and air attacks. But most importantly, neither the soldiers nor the women themselves wanted clubmobilers to stay safely in the rear. A member of Group E commented scathingly, "Some think we'd be better off at home, where women's place used to be...about 200 years ago." ${ }^{, 15}$ Indeed, clubmobilers often chose to get closer to the front. Group H, for example, lived within 15 miles of the battle for Metz, and were extremely

\footnotetext{
${ }^{12}$ Gretchen Schuyler to "Katie and all the rest," day after election [November 8, 1944], Box 2, Folder “\#43a—letter (Day after election)," Papers of Gretchen Schuyler. I date the letter November 8, 1944, because Gretchen specifically references Dewey's loss of the presidential election, which took place on November 7, 1944. "United States presidential election of 1944," Encyclopadia Britannica, last modified October 31, 2019, https://www.britannica.com/event/United-States-presidential-election-of-1944.

${ }^{13}$ Chadwick, "Beyond the Lightline," 34.

${ }^{14}$ Fay, "Through a Donut Hole," Chapter 20.

${ }^{15}$ Morgan, The Clubmobile, 119.
} 
disappointed when "suddenly one day after seven weeks an order came 'Get the hell back, and quick'! We never did quite figure out what the reasoning was unless [the] Corps Forward [command post] was a bit red faced at having a bunch of women up ahead of them." ${ }^{16}$ Having women closer to the front than the corps' commanders represented a direct challenge to the gendered image of the soldier-as-protector. The description of commanders as "red faced," and thus embarrassed and/or indignant, suggests that the men were more concerned with their own image than the women's safety. However, many clubmobilers wanted to be where the action was, and some only reluctantly followed orders to stay back. Group L's Mary Small complained to her family that being kept close to base "is never the same: we feel far removed from the war, knowing less about what is happening than you probably." 17

Despite some attempts to keep the women out of danger, the military allowed clubmobilers a remarkable amount of freedom to travel the lines. Indeed, George Korson asserted that clubmobiles "mov[ed] with more freedom than many soldiers. Even war correspondents could not drive in and out of battle lines as they did every day." ${ }^{18}$ Clubmobilers' freedom of movement sometimes inadvertently placed them in danger. Soon after Group F's arrival on the Continent, three of their clubmobiles served infantry troops without a soldier escort; one group member recalled, "Later when we were safely home we learned that through some accident we had driven some 10 miles through enemy territory, unescorted." ${ }^{19}$ In a similar incident, Group D's Ellie Green commented, "If we had been something more noticeable than a

\footnotetext{
${ }^{16}$ Morgan, The Clubmobile, 129. Army Corps headquarters during WWII were usually divided into forward and rear echelons. The Corps commander, assistant commander, chiefs of staff, and other top Corps personnel staffed the main command post, located in the forward echelon. Major Bruce R. Pirnie, "Division and Corps Command Posts in World War II," unclassified report (Washington, D.C.: U.S. Army Center of Military History, 1986), 9, https://apps.dtic.mil/dtic/tr/fulltext/u2/a167405.pdf.

${ }^{17}$ Mary Churchill Small to "everyone," Washington's Birthday 1945, Folder "MCS Letters from Europe [3]," Papers of Mary Churchill Small.

${ }^{18}$ Korson, At His Side, 280.

19 "Doughgirl's Diary..."
} 
Hillman [truck], someone would have told us that we were going the wrong way, but as it was we were 1/4 mile from the front when a friendly jeep driver suggested that we'd be more comfortable if we tried another direction." Hillmans were small, notoriously unreliable British trucks issued to each clubmobile group to carry supplies. ${ }^{20}$ Though they were less conspicuous than a clubmobile, the fact that the women got within $1 / 4$ mile of the front demonstrates that the presence of clubmobilers was an accepted part of life near the front lines, while also highlighting the potentially dangerous consequences of any mistakes the women made.

Soldiers were both surprised and impressed by the women's ability to cope with the dangers of living in a combat zone. In November 1944, Group C's hotel came under fire, prompting their evacuation; though the hotel was hit, all the women escaped unscathed. Colonel Albert H. Peyton, who witnessed the event, reported, "The girls, without exception, were grand. It was a trying experience but there was no complaining, no confusion, no hysteria, no evidence of fear, they laughed and joked and kidded each other." Peyton's observations demonstrate the era's concern that women were not strong enough to face the dangers of war and would succumb to "hysteria." However, after weathering a total of seventeen shells, he noted, "Next morning the girls hastily gathered their belongings, sharing clothing and equipment as necessary, and were right on the job as usual." Their attitude and dedication proved their worth to Peyton, who concluded, "Watching these American girls we felt a surge of pride. [...] They are a great help. They take doughnuts and coffee as far forward as commanders will allow them to go. [...] They are making a vital contribution to morale."21

As Peyton alluded, many commanders recognized how much the mere presence of the women would do for their men, and often allowed, or even invited, clubmobilers to within a

\footnotetext{
${ }^{20}$ Green, "Journal," 45, 47.

${ }^{21}$ Morgan, The Clubmobile, 160.
} 
stone's throw of the front lines. On one occasion, Group K's captain recalled, "two of our clubmobiles beat the infantry into a town." Soldier guides directed them to drive past a unit in battle formation; when they arrived in an empty German town, the women asked, "“But where are the men' [...] 'Oh, they'll be here shortly, you passed them on the road. They're going to take this town this afternoon. [...] the tanks went through yesterday, but the infantry hasn't taken it yet.' 'What do you mean, the Infantry's going to take it—Group "K" has just taken it!" When the soldiers arrived, they were shocked to find clubmobilers already established, music blaring; they told the women, " "this is the first time the infantry's been rear eschelon [sic].",22

Similarly, Nathalie Fallon recalled a stop made in fall 1944: "A quiet, dark haired lieutenant $[\ldots]$ asked us if we would go down and have a word with some of his men, who were dug in beyond some trees. It meant running, bent double, across a clearing and over two plowed fields. The Germans have a fairly good observation post on a hill a mile or so away. We crawled the last few yards, flat on our stomachs." The lieutenant did not hesitate to ask the clubmobilers to visit his men, despite the danger, and Nathalie firmly believed "it was worth the risk" to cheer them up. ${ }^{23}$ Soldiers found it comforting to see a female face peering over the edge of their foxholes, for they believed that the military would not allow the women into truly dangerous areas. Mary Small explained, "There is no satisfaction like that of serving the doughboys, particularly when we're close enough to the front to startle them and make them think (and this of course is thereal [sic] point) that things can't be too bad if the girls are up here."24

The Red Cross emphasized that the depravations the women endured allowed them to do their jobs well. A Harper's Bazaar article on Red Cross workers noted, "But what the soldier likes best is the fact that $[\ldots]$ there, on the edge of the danger he has to fight in, are women from

\footnotetext{
${ }^{22}$ Fay, "Through a Donut Hole," Chapter 20.

${ }^{23}$ Chadwick, "Beyond the Lightline," 22-3.

${ }^{24}$ Mary Churchill Small to "everyone," 21 April 1945.
} 
the U.S.A. who have come a long way, as he has; who have chilblains like him from cold and mud; who like him wash their faces and wool socks in a battle helmet; who like him want letters from home; and who like him are in uniform and in service and will stay until the job is done." 25 Sharing these experiences with the soldier allowed her to understand what he was going through as no one at home could. That she had volunteered for this life in order to serve the soldiers made them feel all the more appreciated.

In this case, the similarities between clubmobile life and the soldier's experience were portrayed as positive because they allowed her to connect with the soldier. Ironically, though clubmobilers were not part of the military, their experiences were far more similar to a field soldier's than those of uniformed servicewomen working behind the lines. By emphasizing the similarities in their experiences and painting a picture of relative equality, such articles both reassured parents that their daughters' sacrifices were necessary and de-sexualized the women. The positive effect of shared experiences on soldiers' morale outweighed any concerns that women should not be living in such conditions, for the men were the priority. Additionally, by emphasizing "chilblains" and the lack of adequate shower facilities, the article highlighted that clubmobilers were not there to entice men; in fact, they were as homesick as the soldiers were, more concerned with their families than with the opposite sex. ${ }^{26}$

Though ostensibly concerned with the women's safety, soldiers knew that clubmobilers also faced difficult, dangerous conditions. Indeed, in many instances the military seemed to

\footnotetext{
25 “American Red Cross-Western Front," Harper's Bazaar, March 1945, 160, Nancy Bastien Chase, Box 1, Folder 10, Clubmobile Service Collection.

${ }^{26}$ Maureen Honey has found that publications aimed at middle-class readers were more likely to emphasize egalitarian images of women's home front war work than working-class publications. She asserts that this was, in part, an attempt to make blue-collar war industry jobs more palatable to middle-class women who lacked an economic imperative to work. While Red Cross service was quite different from women's home front war work, this Harper's Bazaar article was similarly designed to make Red Cross work more acceptable to its middle-class readers. Maureen Honey, "The Working-Class Woman and Recruitment Propaganda during World War II: Class Differences in the Portrayal of War Work," Signs 8, no. 4 (Summer 1983): 672-87, https://www.jstor.org/stable/3173689.
} 
ignore the dangers, allowing clubmobilers freedom of movement and inviting them into foxholes and uncaptured towns. As the Harper's Bazaar article noted, many soldiers celebrated the risks the women took as representative of their patriotism and devotion to the men. This attitude, which seems contradictory to wartime notions of gender roles, stemmed from the men's gratitude to the women, as well as experiences like the shelling of Group C's hotel, which demonstrated that the women were perfectly capable of taking care of themselves. However, it was also a result of the women's noncombatant status, which implied that, despite their proximity to the lines, they would not be engaged in the fighting and were therefore in only the same amount of danger as civilians in the area. The label "noncombatant" implies a supplementary role away from the action, and indeed, clubmobilers' presence gave soldiers a feeling of relative safety because they believed that the women would not be sent to truly dangerous areas. As such, clubmobilers' gender and noncombatant status served to obscure the realities of the dangers they faced, granting them incredible freedom of movement and sometimes increasing their peril.

" We were only strafed" "

Clubmobilers lived in almost constant danger while on the Continent, and their accounts of their experiences acknowledge this. ${ }^{27}$ However, descriptions of perilous events are often accompanied by humor, sarcasm, and qualifiers minimizing the risks involved. In fact, some of the women asserted that they were ignorant of the true extent of their danger; one clubmobiler claimed, "Some think we're so brave, but we really don't know enough to be scared." ${ }^{28}$ However, this statement does the women a disservice. Though their stories are filled with levity and joy, clubmobilers understood the dangers they faced and the dark realities of war. In summarizing the content of The Clubmobile-The ARC in the Storm, Marjorie Lee Morgan explained, "To some it

\footnotetext{
${ }^{27}$ Section title: Morgan, The Clubmobile, 134.

${ }^{28}$ Morgan, The Clubmobile, 119.
} 
may sound as though we have taken the war rather light-heartedly [...] We need no diaries to remind us of its tragedies [...] The humor which we saw in it all we recorded in our reports and diaries. This same humor, which we used to color and make fun of our menial tasks, the American soldier used to make combat bearable." ${ }^{29}$ The dangers they faced were an inescapable part of their life in the combat zone; their descriptions of such perils as relatively insignificant helped the women cope with their situation and do their job.

Whether travelling the lines or serving, the women's lives were often at risk. Daily drives were punctuated with signs reading, "Mines cleared to hedges." 30 Clubmobilers serving in Germany lacked even this small comfort, as Ellie Green recalled: “Two kilometers outside of Aachen we passed a sign to the effect: 'The road ahead is not cleared of mines and booby traps.' [...] Kitty [Smoot] slowed the car down to a creep, and picked her way right where other cars had obviously gone." ${ }^{31}$ Mines were often the least of the dangers the women encountered, as Group G discovered: "It was while they were in Luneville that the girls had their first experience of being shot at by snipers.” No one was injured, and Group G gaily recounted the story of Florence Swanson "jumping up and down frantically ordering, 'Put that flashlight out," only to realize the offending light was in her own hand. ${ }^{32}$ Despite the levity with which this incident was retold, Florence's reaction demonstrates that she understood only too well the danger she faced.

Of course, clubmobilers were not immune to shells or shrapnel. On several occasions, Elma Ernst described vehicles being destroyed overnight: "we discovered that the shell had landed about sixty feet from our gate, and the two German cars we had parked right outside,

\footnotetext{
${ }^{29}$ Morgan, The Clubmobile, 12, 178.

30 "Doughgirl's Diary..."

${ }^{31}$ Green, "Journal," 50.

${ }^{32}$ Morgan, The Clubmobile, 166.
} 
were almost beyond recognition. ${ }^{, 33}$ Other episodes presented more immediate danger. While leaving an outfit after serving, a member of Group D recalled, "Kay (driving) ran over a pile of hand grenades. The crowd of GI's dispersed in all directions. 'Happily,' said Jan, 'they were all duds. That was a terrible day. The fat spilled all over the floor, too." ${ }^{34}$ While equating the spilling of the fat with running over grenades was likely a coping mechanism, it also indicates how seriously clubmobilers took their job; spilling the fat affected donut making, in addition to making a mess, and thus was a serious occurrence for any crew.

Though clubmobilers were not ignorant of the dangers they faced, they knew that they could not allow themselves to be paralyzed by fear, but must continue to do their job. Members of Group D recalled a conversation with the crew of the Twentieth Century one autumn evening: “'What happened?' 'Nothing. We were only strafed,' said Helen [Potter], as if strafing was a daily occurrence in Wyoming." ${ }^{35}$ Reflecting on her time overseas, Group K Captain Elma Ernst remembered, "One night a clubmobile crew would come home with tales of being caught in artillery fire, another one with spending an hour in a fox hole, another of being in a town that was bombarded ten minutes after they left, another of seeing our men capture a Jerry hiding in a church tower directly above them, directing artillery fire onto the town - each day a guardian angel saw the trucks home. ${ }^{, 36}$ While she acknowledged that any of these events could have been fatal, Elma also accepted that this was to be expected in wartime. Similarly, Gretchen Schuyler, captain of Group F, explained to her family, "When we first arrived over here I used to sweat out the return of each Clubmobile at night. I still hate it when they don't reach here by darkness [...]

\footnotetext{
${ }^{33}$ Fay, "Through a Donut Hole," Chapter 15. Many clubmobilers recount gaining possession of captured French and/or German cars, either through their own initiative or as gifts from soldier friends. Another example of the destruction of a captured car by a shell can be found in Chadwick, "Beyond the Lightline," 41.

${ }_{35}^{34}$ Morgan, The Clubmobile, 134. Kay and Jan were Kay Marshall and Janet Whittaker of Group D.

${ }^{35}$ Morgan, The Clubmobile, 134.

${ }^{36}$ Fay, "Through a Donut Hole," Chapter 7.
} 
But after many crews couldn't make it and arrived safely the next morning I began to take it more easily. Anyway there is nothing to worry about because if they make it safely... why worry; and if they don't it is just too bad! So why worry. (It sounds easy to say...but I still don't like it much.)"37 Though she recognized the callousness of such an attitude, Gretchen knew that it would help her do her job and maintain her own sanity.

While their vehicles and living quarters often sustained damage, the women themselves were much luckier. Reflecting on her service, Mary Lou(ise) Pearce recalled, "I saw a lot during my time spent in an active war zone and had several very narrow escapes myself. You don't get as close to the actual fighting as the ARC did and not consider yourself lucky that you made it home." 38 Rosemary "Rosie" Langheldt recalled that Red Cross workers "had to sign releases not to sue in case of injury or loss of life." ${ }^{39}$ Indeed, the Red Cross carried insurance on its overseas personnel, which paid $\$ 2000$ "in the event of death while on foreign assignment, plus health, accident, and sickness insurance, which provides payment, for total disability, of a weekly indemnity of $\$ 25.00,[\ldots]$ continuing for not more than one hundred consecutive weeks." 40 This was not just a formality; many clubmobilers were injured, and a few killed, during their service.

Despite the frequency with which they were under fire, there were remarkably few casualties among clubmobilers. Group E recalled, "Jerry [the German army] managed to throw some shells at us one afternoon [...] the piece of shrapnel that hit [Jane Janzer's] leg had hit too many other things first and did not even tear her trousers." ${ }^{41}$ Jane's luck was not unique; the group captain recounted that members of Group $\mathrm{K}$ “were living with the engineers [of the $80^{\text {th }}$

\footnotetext{
${ }^{37}$ Gretchen Schuyler to "family," 16 September 1944.

${ }^{38}$ Hart, "This is the Way it Was," 48.

${ }^{39}$ Norwalk, Dearest Ones, x.

${ }^{40}$ Richard F. Allen, Vice Chairman of Insular and Foreign Operations, American Red Cross, to Jean U. Hemingway, 24 May 1944, Jean Hemingway Hackleman, Box 2, Folder 9, Clubmobile Service Collection. A payout of \$2000 in 1945 would be the equivalent of approximately \$28,500 in 2020. Ian Webster, "Value of \$1 from 1945 to 2020 ," CPI Inflation Calculator, accessed June 26, 2020, https://www.in2013dollars.com/us/inflation/1945?amount=1.

${ }^{41}$ Morgan, The Clubmobile, 117.
} 
Infantry Division] in a town called St. Evold. When the Germans had moved out of this town, they had planted a number of time bombs which began going off any time of the day or night, causing a lot of damage and many casualties. The girls stayed throughout, and luckily, were living in a house that hadn't been touched."42

More clubmobilers were injured as a result of their work itself than by enemy action.

Cuts and burns were commonplace, and several clubmobilers also complained of back trouble from lifting heavy coffee urns and flour sacks. ${ }^{43}$ Soon after Thanksgiving, two members of

Group A were badly burned when their stove exploded; one woman's injuries were so severe that she was sent home. ${ }^{44}$ Mary "Chichi" Metcalfe commented at the end of war, "it was amazing that only two from group A had been sent home for medical reasons." ${ }^{45}$ Potentially lifethreatening injuries were not uncommon; only a few days before VE Day, Group E's (Jane) Anne Jack wrote to her parents, "Well, it seems I'm ending this war in a most undignified waylying in bed in the hospital with a broken collarbone." While directing the Augusta in a U-turn, she was hit and almost crushed under the clubmobile. Luckily, a roadside culvert stopped the Augusta, leaving Anne with only a broken collarbone. ${ }^{46}$

Gretchen Schuyler commented that it was unsurprising "that the first ARC girl to be killed was a Clubmobile gal. We do get right up in there." ${ }^{47}$ At least six clubmobilers were killed

\footnotetext{
${ }^{42}$ Fay, "Through a Donut Hole," Chapter 23.

${ }^{43}$ Chichi Metcalfe, for example, hurt her back in early October 1944 while moving coffee urns and was in excruciating pain for several days. Rexford, Battlestars \& Doughnuts, 57-8.

${ }^{44}$ Rexford, Battlestars \& Doughnuts, 69. Another member of Group A was burned in the face when a field range caught fire in late August 1944. Boy, "The Experiences of One American Red Cross Clubmobiler," 133.

${ }^{45}$ Rexford, Battlestars \& Doughnuts, 133.

${ }^{46}$ Jane Anne Jack to Mr. \& Mrs. N. T. McKee (father and [step?]mother), 4 May 1945, Jane Anne McKee Jack, Box 8 , Folder 2, Clubmobile Service Collection.

${ }^{47}$ Gretchen Schuyler to Mrs. C.J. McCarthy, 12 January 1945, Box 1, Folder 1945, Papers of Gretchen Schuyler. Gretchen's statement is not strictly true; the first American Red Cross woman killed in action during World War II was Esther Richards, a hospital worker, who died in a February 1944 attack on the $95^{\text {th }}$ Evacuation Hospital at Anzio. She was posthumously awarded the Purple Heart. However, the clubmobiler to whom Gretchen refers was the first Red Cross woman killed by enemy action on the Western Front. Korson, At His Side, 255-7, and Morgan, The Clubmobile, 11.
} 
in the course of their service: (Dorothy) Jane Burdge, Elizabeth "Liz" Richardson, Helen "Polly" Thompson, Harriet Engelhardt, Portia Miller, and Ann Kathleen "Katie" Cullen. ${ }^{48}$ Two deaths occurred in airplane crashes and three in vehicle accidents in the summer or fall of 1945 . The sixth, Katie Cullen, was a direct result of enemy action.

Jane Burdge, of Group F, was killed on May 1, 1945. She and her crewmates were taking plane rides on an airstrip near their serving area in Munsa, Germany. On Jane's turn, the plane hit the top of a tree during landing and crashed, killing Jane and the pilot instantly. ${ }^{49}$ The group captain described Jane's death as "a great blow" for Group F: "It is pretty hard to take, when we have squeaked through so many times when enemy action might have taken a toll, and now when hostilities are most [sic] over, to have someone killed just having fun!" ${ }^{50}$ Jane was buried in the US Army Cemetery in Eisenach, Germany, on May 7, 1945; her remains now rest in the Netherlands American Cemetery. ${ }^{51}$

On July 25, 1945, Liz Richardson hitched a ride on a military plane, as many clubmobilers did when in need of transport, to fly to Paris for leave. Attempting to orient himself in a heavy fog, the pilot struck some trees and crashed. Both he and Liz, the only passenger, were killed instantly. Though originally buried in St. Andre, 50 miles west of Paris, Liz's remains now rest in the American Cemetery in Normandy, one of only four women interred there. ${ }^{52}$

\footnotetext{
${ }^{48}$ There is no comprehensive list, as far as I am aware, of clubmobilers killed during their service; my list too may be incomplete. Indeed, the most comprehensive source on clubmobile service, Marjorie Lee Morgan's The Clubmobile - The ARC in the Storm, mentions only the death of Katie Cullen during the Battle of the Bulge. This is perhaps because this work does not address clubmobile life after VE Day. Accounts of the other deaths are drawn from the works of other scholars and the memoirs and papers of fellow clubmobilers.

${ }^{49}$ Gretchen Schuyler to Camilla Moss (Personnel Director), Frank deGanahl (Regional Executive), and Virginia Ellis (1st Army Clubmobile Supervisor), 3 May 1945, Box 2, unlabeled folder, Papers of Gretchen Schuyler.

${ }^{50}$ Gretchen Schuyler to "family," 4 May 1945, Box 1, Folder 1945, Papers of Gretchen Schuyler.

${ }^{51}$ Gretchen Schuyler to "family," addressed to Mrs. C.J. McCarthy, 8 May 1945, Box 1, Folder 1945, Papers of Gretchen Schuyler; Gretchen Schuyler to Camilla Moss, Frank deGanahl, and Virginia Ellis, 3 May 1945; and "Search ABMC Burials and Memorials," American Battle Monuments Commission, accessed April 28, 2020, https://www.abmc.gov/database-search.

${ }^{52}$ Madison, Slinging Doughnuts for the Boys, 244-7, 254, and Lambright, They Also Served, "Introduction."
} 
Both Harriet Engelhardt (Group H) and Polly Thompson (Group K) were killed in automobile accidents in the fall of 1945. Harriet lost control of the Jeep she was driving to her post in Munich during a heavy rainstorm and was killed on impact on October 26, 1945, less than a week before she was scheduled to return home after almost two years overseas. ${ }^{53}$ Polly and a fellow clubmobiler were travelling to Italy to locate Polly's brother's grave. Their Jeep was struck on a mountain road by an Italian military lorry transporting German POWs, and Polly died a few hours later in a local farmhouse. She was buried beside her brother in Florence, Italy. ${ }^{54}$

Portia Miller was crushed beneath the wheels of her clubmobile in August 1945, not long after she had joined Group H. As fellow group member Betty Jane "B.J." Thomas recounted, "the road was thickly covered with wet leaves, and somehow Portia slipped on them and was under the truck before Barbara could stop it. The huge dual tires ran over her pelvis." Portia died from her injuries five days later. The fact that her death was due to an accident caused by her own crewmember made it all the more difficult for Group H; B.J. recalled that Barbara lived in “an abyss of horror" following Portia's death. ${ }^{55}$

Katie Cullen was the only clubmobiler killed by enemy action during World War II. She was being treated for a "bad cold" in a field hospital in Herve, Belgium, which was struck by a German shell during an early attack of the Battle of the Bulge on December 20, 1944, the morning she was scheduled to return to Group B. Katie died two hours later, the only casualty of

\footnotetext{
${ }^{53}$ Ramsey, “'Girls' in Name Only," 134.

${ }^{54}$ Chadwick, "Beyond the Lightline," 140-2. Polly's brother, a soldier in the $7^{\text {th }}$ Army, had been listed as missing in action in the winter of 1944; though Nathalie does not clarify this point, it appears that his remains were discovered sometime between the spring and fall of 1945. Chadwick, "Beyond the Lightline," 87. A search of the grave records at the Florence American Cemetery does not yield any women with the last name Thompson, suggesting that Polly (and her brother, whose first name I do not know) may have been repatriated at some point following the war. It is also possible that Nathalie's secondhand account of the details of Polly's death is inaccurate. "Search ABMC Burials and Memorials."

${ }^{55}$ Olewiler, A Woman in a Man's War, 177-8.
} 
the attack. She had served in the Red Cross from June 1943 and was one of the first clubmobilers on the Continent. Katie was buried in the Henri-Chapelle American Cemetery in Belgium. ${ }^{56}$

Though the majority of these deaths were due to accidents that occurred after hostilities in the ETO had ceased, they are nevertheless attributable to these women's Red Cross service. Indeed, with their proximity to the front and the number of times they faced the dangers of war, it is remarkable that only one clubmobiler was killed by enemy fire.

\section{"If you are lucky, you'll be captured"”}

Though they professed a concern for the women's safety, the military often left clubmobilers to fend for themselves in dangerous situations. ${ }^{57}$ Recognizing this reality, some clubmobilers acquired guns, often taken from captured German soldiers. Elma Ernst recalled, "The girls went gun crazy just like the boys, and the table conversation was more apt to be about P 38's and Lugers than clothes. Swords and shotguns and daggers were always carted around, and even a few were brought home. I think the funniest sight was when we were going through Customs in New York and Sally Craighill pulled out a dismantled captured German sub-machine gun to declare." ${ }^{58}$ Though some of these weapons may have been mere souvenirs, other women acquired guns with the express intent of protecting themselves if necessary. When Gretchen Schuyler heard shots in a German town one night, she recalled, "For awhile I thought seriously of putting a shell in the chamber of my captured P-38!"59 Clearly, some of the women took steps to ensure their own safety, knowing that the military often could not protect them.

\footnotetext{
${ }^{56}$ Morgan, The Clubmobile, 11. A search of the grave records of the Henri-Chapelle American Cemetery reveals that Katie is no longer buried there, suggesting that her remains were repatriated after the war. Indeed, the first shipments of American war dead repatriated to the US following WWII were from Henri-Chapelle. "Search ABMC Burials and Memorials," and "Henri-Chapelle American Cemetery," American Battle Monuments Commission, accessed April 28, 2020, https://www.abmc.gov/database-search.

${ }^{57}$ Section title: Morgan, The Clubmobile, 150.

${ }^{58}$ Fay, "Through a Donut Hole," Chapter 25.

${ }^{59}$ Gretchen Schuyler to "Katie and all the rest," 2 April 1945, Box 1, Folder 1945, Papers of Gretchen Schuyler.
} 
Indeed, clubmobilers caught in one of the most pivotal battles of the war were largely left without military protection. In December 1944, the German army made its last major effort to stop the Allied advance and took advantage of the Allies' tactical miscalculations to break through a weak part of the Allied line in Belgium, resulting in the Battle of the Bulge. Several clubmobile groups were operating in the area of the battle, and Group F in particular was caught in the middle of the fighting. Though the women had few, if any, ways to defend themselves, they often had to deal with the circumstances of the breakthrough without military protection.

Though contemporary assumptions stated that women had no place in a combat zone, Jill Pitts' recollection of the initial attacks of the Battle of the Bulge demonstrates that the clubmobilers of Group F were expected to react to the battle in a military manner:

The next morning we were completely surrounded by the enemy and with no communication or roads open for the passage of supplies [...] We turned all of our supplies over to the Army and they used the doughnut flour to make pancakes. The coffee, too, was very welcome. We aided at a near-by hastily erected hospital by trying to cheer the wounded, passing out candy, gum, cigarettes and smiles. [...] Later that night we were told to pack our musettes (small shoulder bags) and prepare to crawl thru the lines under the protection of black-out. I put an incendary [sic] bomb in the clubmobile as we were not leaving our equipment and personal supplies for the enemy. ${ }^{60}$

Even in the thick of war, the women were still expected to subordinate their own needs to the military's by giving the few supplies they had to the soldiers and destroying any remaining equipment to prevent it from falling into enemy hands.

Like Jill's crew, half of Group F was in the field when the attack began; luckily, they all managed to reunite safely with the group. One of their replacement drivers, Margaret "Peggy" Henry, had been working in Clervaux, Luxembourg, which was cut off in the first attacks of the Bulge. An officer told Peggy, “'If you are lucky, you'll be captured,” and ordered her to burn

\footnotetext{
60 “After personal interviews...," Jill Pitts Knappenberger, Box 10, Folder 9, Clubmobile Service Collection.
} 
her letters and photos. ${ }^{61}$ The unit of American soldiers stationed in Clervaux placed Peggy in charge of a small group of pro-American civilians as they hid and escaped under cover of darkness. Though Group F reported that the soldiers "threw their arms around Peggy to protect her" from incoming bullets, the men also asked Peggy to place herself in more danger to assist the civilians and, by extension, the military that had promised to protect them. ${ }^{62}$ In asking Peggy to be responsible for the civilians, the military essentially drafted her into service, mobilizing her as a member of the unit.

Recounting their experiences during the battle, an unnamed member of Group F recalled, "If they complained at all, it was because they weren't working. It made them restless." In the initial hours of the battle, when the group was scattered and communication was impossible, the women needed the distraction of work to prevent them from despairing of the fate of their friends. Those caught in the fighting did their best to help the military as they attempted to reunite with Group F. The crew of the Annapolis, for example, worked for several days at an impromptu field hospital, finally helping to evacuate all the living patients as the army retreated. After reuniting with the bulk of Group F at Arlon, the Annapolis crew were determined to return, and were "crushed that [the group captain] would not let them go back. But [she] was the boss, so they stayed." The crew of the Austin was also eager to get back to work: “"There'll be convoys coming through all the time. Can't we feed 'em?'” Unfortunately, they had been forced to abandon their supplies. As they retreated from Arlon, Group F squeezed "five truckloads of U.S. Army mail" into their "already heavily-laden Clubmobiles." If they had not taken it, the mail would have been burned, and the women "knew what that mail, however late it might be

\footnotetext{
${ }^{61}$ Though clubmobilers carried a non-combatant identification card in the event of capture, I have found no accounts of any other training or preparation for such a scenario.

${ }^{62}$ Morgan, The Clubmobile, 150-1.
} 
delivered, would mean to the GI's, so they made room for it." ${ }^{\text {"63 }}$ As civilian Red Cross employees, they could not transport weapons or other war materiel, leaving them largely unarmed and unprotected, yet still supporting the soldiers as best they could. Group F's Battle of the Bulge experiences demonstrate the extent to which the military relied on the women, not only for morale services, but also for material support in the midst of a battle. Despite objections to female military service, clubmobilers sometimes became de facto soldiers.

\section{"[P] eaceful things crumble and disappear"}

Because they followed so close to the front lines, clubmobilers were exposed not only to danger, but also to the aftermath of battle and the moral dilemmas of war. ${ }^{64}$ Sights of total devastation and unburied dead became commonplace. While based near Nancy, France, in October 1944, Nathalie Fallon commented, "The Germans were so close that we could not use the Tannoy [PA system]. Their dead were still lying in the fields. One meadow was filled with a herd of cows, lying on their backs, their hooves pointing stiffly at the sky, all killed by a shell burst. [...] I have never seen such devastation., ${ }^{, 65}$

In addition to the dead, clubmobilers also encountered German prisoners of war (POWs or PWs). ${ }^{66}$ Elma Ernst recalled, "It was not unusual for a clubmobile to return to home base at night with news that German troops had surrendered to them as they drove along a road." ${ }^{\prime 67}$ Eager to be captured by the Americans, not the Russians, these German soldiers granted the women military authority they did not officially have. Though clubmobilers were not officially sanctioned to accept surrenders, they became so commonplace that the women did as they saw fit.

\footnotetext{
${ }^{63}$ Morgan, The Clubmobile, 151-3.

${ }^{64}$ Section title: Mary Churchill Small to "family," ND [14 December?] 1944, Folder "MCS Letters from Europe [1]," Papers of Mary Churchill Small.

${ }^{65}$ Chadwick, "Beyond the Lightline," 21.

${ }^{66}$ Although modern writers usually use the abbreviation "POWs," many WWII-era sources utilize "PWs."

${ }^{67}$ Elma E. Fay, "Tale begins in England in '44 and ends in Germany in '45," Elma Ernst Fay, Box 2, Folder 5, Clubmobile Service Collection.
} 
Nathalie Fallon recalled, "We had two surrender to us this morning and then they were annoyed because we made them walk, not ride, back to the PW cage. ${ }^{.68}$ The Red Cross had not anticipated that clubmobilers would have to deal with surrendering Germans, for they saw the women as noncombatant workers there solely to improve American morale. However, this view ignored the realities the women faced while operating alongside the soldiers, which often forced the women to functionally act as soldiers. This reality has been further obscured by the focus on servicewomen in the history of the Second World War, assuming that their membership in the military represents the closest a woman could come to soldiering in the 1940s.

Though clubmobilers rarely commented on the emotional toll of their experiences, it is clear that the constant destruction affected them. Gretchen Schuyler confided to her family, "We follow so close to the front line elements that [the German civilians] are often still laboring under the shock of having just been conquered. [...] The dead animals and some Krauts are still to be seen. Broken and blasted vehicles clutter the highway....and then we burst into view. I can hardly blame the Krauts.It [sic] is too much for us sometimes, too." ${ }^{69}$ This period was difficult for clubmobilers, who not only had to deal with the devastation that surrounded them, but also interact with the (often hostile) German population, a far cry from the French who welcomed them throughout the fall. Even the French attitude had made some of the women uncomfortable; B.J. Thomas commented, “I don't suppose any Americans went across France with quite the mixed emotions we had. The GI's could take it as their just due, even if they were never to see action of any kind, but sometimes we felt a little ashamed at reaping the harvest someone else

\footnotetext{
${ }^{68}$ Chadwick, "Beyond the Lightline," 87.

${ }^{69}$ Gretchen Schuyler to "Katie and all the rest," addressed to Mrs. C.J. McCarthy, 21 April 1945, Box 1, Folder 1945, Papers of Gretchen Schuyler.
} 
had sown."70 The French showered the Americans, including clubmobilers, with praise and what gifts they could provide, leaving the women feeling that they were not deserving of thanks.

Living in Germany presented even more challenges. Mary Small reflected, “I just don’t understand war: when is an enemy soldier not an enemy? This town has been taken and occupied by Americans, yet Hitler's henchmen apparently wander around at will." Many clubmobilers stayed in houses whose owners were unceremoniously ordered out. Though some women took this in stride, Mary confided to her family, “instead of deriving the victor's glee from seeing them turned out of their houses for us, I find the whole thing distinctly unpleasant. Imagine taking over a house with the half-eaten meal still warm on the stove!"71

Taking over civilian houses was only one instance of life in Germany that made Mary uncomfortable. She commented that the issue of punishing the Nazis was "neither as interesting nor as disturbing as the ethical one involving our behavior toward civilians. Many of us find it hard to hate every man, woman and child because they are German.” However, Mary also noted that it was easy for Germans to claim that they had been forced to support the Nazis:

Is the failure to resist evil a crime in itself? [...] Of course, if you divorce the whole thing from the facts of Germany's role in this war and put it on purely ethical grounds, don't you have to admit that the person who does anything — wrong or right — because he believes in it with his whole heart and soul is more to be admired than the one who just takes the easiest way? [...] Which brings this vicious circle back to its starting point: how to know who was what, when $95 \%$ of the population of every town comes crying to the conquering Americans with the same tale, "I had to pretend to support Hitler." In the end we will only have punished those who have the courage of their convictions. ${ }^{72}$

The distastefulness and moral dilemmas that arose from interacting with German civilians were yet another unforeseen stress placed on the women, who had to navigate the hostile atmosphere of captured German towns while doing their best to remain cheerful and encouraging to the GIs.

\footnotetext{
${ }^{70}$ Olewiler, A Woman in a Man's War, 113.

${ }^{71}$ Mary Churchill Small to "family," 2 April 1945.

72 Mary Churchill Small to "family," 2 April 1945.
} 
Witnessing the constant destruction also caused Mary to consider the war's long-term effects on Europe. While serving in France, she commented on the stark contrast between French towns with "every window blown out" and the "huge trucks and bristling tanks" that filled them, reflecting, "It is a tragic fact [...] that only the instruments of war can withstand war; peaceful things crumble and disappear." This applied not only to towns but to the French people as well: "Their homes are ruined, they are literally dying of starvation (the number of funerals each day right here in town is amazing), they have no way of starting to rebuild." The suffering that she witnessed made Mary question the high ideals for which the US was supposedly fighting: "The U.S.A. can't undertake to feed the world and win the war, yet what is the point of the latter without something being done for the 'liberated' peoples. Race—democracy—-freedom—sound pretty hollow when you're cold and hungry and are wandering along a half-destroyed road with everything you have left junked into a battered wheel-barrow or an old baby carriage."73

In addition to the destruction and general civilian suffering, most clubmobilers had some experience with concentration camps, either secondhand or in person. Angie Petesch recalled that though Group $\mathrm{H}$ was forbidden from visiting the camps, they nevertheless heard tales of the "[h] undreds of bodies of slave laborers" found there. ${ }^{74}$ Several clubmobile groups visited the camps themselves. ${ }^{75}$ Group A’s Jane Phillips remembered, “One day we went to Buchenwald concentration camp where American troops liberated 21,000 survivors. Some of the men still

\footnotetext{
${ }^{73}$ Mary Churchill Small to "family," ND [14 December?] 1944.

${ }^{74}$ Petesch, War Through the Hole of a Donut, 211. Angie does not specify which camp this was; based on the memoir of another member of Group H, it likely refers to Ohrdruf, part of the Buchenwald network. Hart, "This is the Way it Was," 42.

${ }^{75}$ Members of Group F, for example, visited Ohrdruf on April 14, 1945, and the main Buchenwald camp on May 17, 1945. Schuyler, "Operational Outline History of the American Red Cross Clubmobile Group 'F," 18.
} 
there escorted us around the camp $[\ldots]$ The men were skin and bones but so happy to be alive!,”76 These sights would stay with the women for the rest of their lives.

While many such visits occurred weeks after liberation, a few clubmobilers entered newly liberated camps. Though not mentioned in her letters, Elizabeth "Bettie" Walters was one of two Red Cross women who visited Dachau on April 30, 1945, the day after it was liberated by the US Army. In an article written in 1986, Bettie vividly described what she saw: "there were 2,000 or so naked, emaciated bodies stacked and sprawled over each other." She also witnessed the continuing cremation of these bodies: "I was told the men pushing the bodies, one by one, into the cavernous door [of the crematorium] were Russian prisoners who had been doing this for a long time. I don't know how much longer they held this job, but the Army kept them at it $[\ldots]$ It was necessary to continue to prevent further spread of disease. Liberation did not stop the daily dying. ${ }^{, 77}$ Even forty years later, Bettie recalled the shock and horror of the camp.

Bettie did not merely see piles of the dead from afar: "I remember $[\ldots]$ nearly falling over a small body whose face told me he had died at about age 14. His uniform was that of the SS [Schutzstaffel, the German paramilitary group that, among other things, ran the concentration camps]." She also witnessed the very violence that had killed the young guard: "Suddenly, our Colonel grabbed my friend and me by the arm, pulled us toward the gates through the crowd. But not fast enough. We both saw two SS troopers on the ground, eyes being gouged by three or four men in prison garb." ${ }^{78}$ Though the officer escorting them attempted to shield Bettie and her companion from the violence, he could not prevent them from witnessing the horrors of the camp. Indeed, this incident can be seen as a metaphor for much of clubmobilers' experience: though the

\footnotetext{
${ }^{76}$ Jane Weir Phillips, "Some Experiences of Jane Weir Phillips An American Red Cross Clubmobile Girl in World War II December 1943 to July 1945," 19, Jane Weir Phillips Scott, Box 11, Folder 7, Clubmobile Service Collection.

${ }^{77}$ Elizabeth "Bettie" Walters MacInnes, "A Red Cross Girl's Memories of Dachau," Walters Family Correspondence.

${ }^{78}$ MacInnes, “A Red Cross Girl's Memories of Dachau.”
} 
Red Cross and the military valued their innocence and femininity, any attempt to shield the women from the violence of war was ultimately both futile and unnecessary, for the women did not need male protection to survive in the war zone.

Bettie was at the camp as a mere observer; one member of Group D, however, was called upon to bring supplies to a newly liberated camp. Ellie Green described how Kitty Heiusler was dispatched to "collect three sides of beef and haul it to a nearby concentration camp where German political prisoners had been starving for six months, and were dying like flies from malnutrition." Nothing could have prepared Kitty for the camp; upon her return, she told Group D, "I've read about those concentration camps, [...] but I wouldn't have believed it possible. It was just awful. Fortunately, I worked in Hopkins Hospital, so it didn't make me sick. Five of the prisoners had died yesterday. Four died while I was there. The rest of them were too weak to bury the dead. The people were filthy and the odor was excruciating. $[\ldots]$ Some of the people were going around with great running sores, with maggots in them. You could see where others had been hurt, and blood poisoning was setting in. Their legs and arms were just like tooth picks, and there was no flesh on their bones. [...] Food arrived yesterday, but it gave them dysentery. I gave them all the milk I had on the clubmobile (about two cases), and the nurses were going to make a noodle broth."

In addition to food, Ellie recounted that the prisoners lacked basic supplies: "When Kitty arrived, no medical supplies had come in, [so] she turned over her first Aid Kit to the doctors for bandages." Despite her best efforts, this was one time when Kitty felt her inadequacy. As she left, she commented, “'Mercy missions are all right, and there's not one of us that won't help where and when we can, but $[\ldots]$ we're strictly doughnuts." ${ }^{\prime 79}$ The war had been full of situations for

\footnotetext{
${ }^{79}$ Green, "Journal," 63-4. This account, dated April 11, 1945, does not specify which camp Kitty visited. It begins by stating that the group had just arrived in Stathagen. Assuming that this is a misspelling of Stadthagen, it is most likely that Kitty visited Dora-Mittelbau (also known as Mittelbau-Dora, Nordhausen-Dora, Dora-Nordhausen, and Nordhausen). If this is the case, Kitty arrived in the camp on the morning after the remaining prisoners (those who had not been evacuated to Bergen-Belsen) were liberated by US troops. "Liberation of Dora-Mittelbau," Timeline of Events, United States Holocaust Memorial Museum, accessed August 22, 2019, https://www.ushmm.org/learn/timeline-of-events/1942-1945/liberation-of-dora-mittelbau.
} 
which the women had been unprepared; however, in a newly liberated concentration camp, Kitty found one that a clubmobiler could not handle.

Though her experience was not the same as Kitty Heiusler's, Bettie Walters' concentration camp visit is the closest comparison, and there is one significant difference between them: while Kitty was sent alone, Bettie was accompanied by another Red Cross woman ${ }^{80}$ After witnessing the camp alone, with no other women to support her or even fully comprehend what she had seen, Kitty was adamant that this was not a clubmobiler's job, and they should not be called upon for such tasks. Such a visceral reaction is absent from Bettie's account, and while it is possible that the passage of time may have taken some of the edge off of the experience, it is significant that Bettie was not alone in facing the horrors of Dachau. Perhaps it was not the camp, but the lack of companions with whom to share the experience, that made a clubmobiler unequal to the task at hand.

Living so close to the front lines exposed the women to the violence of war, despite some efforts to shield them. Indeed, some commanders invited the women into greater danger, privileging their men's morale over the women's physical and mental well-being. Though clubmobilers were noncombatants assigned to boost military morale, their everyday experiences demonstrate that in many ways, they were essentially serving as soldiers on the front lines, even more so than Special Services troops charged with organizing recreational activities behind the lines. However, their gender and the narrow definition of their role obscured this fact, both at the time and in the historical literature. Despite societal objections to women serving in the military, clubmobilers were sent to the front lines alongside the soldiers. They came under fire repeatedly and had to retreat from the German attacks of the Battle of the Bulge with little guidance from the military. The failure, by both contemporaries and historians, to recognize clubmobilers'

\footnotetext{
${ }^{80}$ Since she does not identify her companion, it is not clear whether she was a clubmobiler.
} 
experiences indicates the limitations that labels like "noncombatant" and "soldier" place on our understanding of war and wartime experiences. Civilian noncombatant clubmobile women had more experience and understanding of the violence and dangers of war than the many male soldiers stationed on a base or behind the lines who did not experience combat situations. However, the combination of their gender and their noncombatant status obscured the realities of the women's experiences, leaving clubmobilers to face not only the physical dangers but also the psychological stresses of war on their own. With almost no training and little support, clubmobilers were expected not only to survive and maintain their own composure, but also to serve as emotional support for the men alongside them. 


\section{Chapter 3: A "nerve racking business": The emotional challenges of clubmobiling}

Though clubmobile women were ostensibly there to serve donuts and coffee to the men, Rosemary "Rosie" Langheldt explained, "Always, wherever we were sent, we were expected to be the friend, the girl next door, the kid sister, the funny aunt, Mom, advisor, sympathizer; to listen, commiserate, cajole, and cheer up the guys [...] We were not nurses; our job was to nurse morale." The image of a "morale nurse" is quite apt for clubmobilers, especially because researchers of war's psychological effects have long ignored the experiences of nurses serving in combat areas. ${ }^{2}$ Unlike nurses, clubmobile women's job did not end when they returned to their base at night, for they were expected to accompany soldiers to parties and on dates whenever possible. A clubmobiler must always be ready to boost a soldier's morale.

However, clubmobilers' efforts to buoy soldiers' morale often took a toll on them, as Eva Christensen recalled: "Being bright, gay and happy all day, cheering up morose apprehensive young men, can be utterly exhausting." 3 Their sense of duty and acceptance of their role placed the women under great emotional strain that went unrecognized by the military and the Red Cross. Scholar James H. Madison notes, "Clubmobile women generally suppressed their own problems as they went about their daily work of lifting soldiers' morale."4 Clubmobilers sacrificed their free hours and sometimes their own morale to keep soldiers' spirits high.

Only the women themselves recognized how hard they worked; some men disregarded clubmobilers' experience, while many others became attached to the generic Red Cross worker, ignoring the women's individuality even as they shared their most intimate war experiences with

\footnotetext{
${ }^{1}$ Chapter title: Elizabeth "Bettie" Walters to Mr. \& Mrs. Aaron Walters, 8 February 1944, Walters Family Correspondence. Norwalk, Dearest Ones, x.

${ }^{2}$ Elizabeth M. Norman, "Coming to Terms with the War: Post-Traumatic Stress Disorder," in Women at War: The Story of Fifty Military Nurses Who Served in Vietnam (Philadelphia: University of Pennsylvania Press, 1990) 143, http://www.jstor.com/stable/j.ctt3fhsqj.17.

${ }^{3}$ Johnson, I Too Shall Wear Purple, 182.

${ }^{4}$ Madison, Slinging Doughnuts for the Boys, xii.
} 
clubmobilers. Despite the gratitude that many soldiers expressed, they had no idea how difficult clubmobilers' job really was, failing to recognize that the men had a profound impact on the women. Ironically, scholars recognize World War II as the marker of a paradigm shift in the field of psychology as psychiatrists began to recognize environmental stress as a primary causal agent of psychiatric issues, rather than a catalyst for individual predispositions. ${ }^{5}$ Despite this newly expanded understanding of the effects of the war environment, psychiatrists and society at large continued to recognize and examine the effects of stress only upon male soldiers and veterans.

This ignorance of the women's struggles continues in scholarly literature on World War II and on the experience of war in general. Though there are many studies of both the psychological effects of war and the shifting ways in which these effects were understood throughout the twentieth century—-from shell shock to combat fatigue and PTSD,—-such literature focuses almost exclusively on the experiences of male soldiers. More recently, scholars have begun to examine the experiences of noncombatants; however, Alex Bierman and Ryan Kelty highlight that such studies refer almost exclusively to refugees and/or children, ignoring those serving alongside soldiers in supplementary roles, whose experiences often closely parallel those of soldiers. ${ }^{6}$ Ignorance of noncombatant experiences, combined with an emphasis on female caregiving, obscured clubmobilers' emotional difficulties and the way they coped with their experiences.

\footnotetext{
${ }^{5}$ Theodore M. Brown, “'Stress' in US Wartime Psychiatry: World War II and the Immediate Aftermath,” in Stress, Shock, and Adaptation in the Twentieth Century, eds. David Cantor and Edmund Ramsden (Rochester: University of Rochester Press, 2014), 121-41, http://www.jstor.com/stable/10.7722/j.ctt4cg6bs.9.

${ }^{6}$ Alex Bierman and Ryan Kelty, "The Threat of War and Psychological Distress Among Civilians Working in Iraq and Afghanistan," Social Psychology Quarterly 77, no. 1 (March 2014): 27-8, http://www.jstor.com/stable/43186713.
} 


\section{"We are veterans"}

A clubmobiler knew that she was there to distract the soldier from the war, to remind him what he was fighting for, and to make him feel that he, and his sacrifices, was valued. ${ }^{7}$ In many ways, it was her firsthand knowledge of the war and the soldiers that allowed a clubmobiler to do her job. In an interview for a sorority publication, Helene Deming explained, "The main purpose of this division [clubmobiles] is to give the men a chance to talk about home to girls who know what they are talking about." ${ }^{8}$ Even if she only spoke to him for a few minutes, a clubmobiler could make a soldier feel that she knew him, that she understood what he faced, and that she cared; she learned quickly that this was the best way to keep his morale high.

Clubmobilers made certain assumptions about the men they would serve, most notably that the soldiers would be white. Nonetheless, white clubmobilers served Black troops both in the UK and on the Continent. Some women seemed to consider this merely a part of their job. Elizabeth "Bettie" Walters, for example, simply noted, "We performed for the negro club tonite [sic]. They were a good audience." ${ }^{9}$ However, many white clubmobilers were uncomfortable serving Black troops. For example, Angela "Angie" Petesch commented, "because it was a colored camp, everybody was more than a little self-conscious. It was most painful." The awkwardness and discomfort made this visit a "complete flop," and Angie noted regretfully, "I

was sick about the whole thing." ${ }^{10}$ In this instance, Angie felt guilty that she was unable to do her duty, demonstrating that, despite her discomfort, she was willing to serve the Black troops.

\footnotetext{
${ }^{7}$ Section title: Madison, Slinging Doughnuts for the Boys, 101.

${ }^{8}$ Helene Deming, "Wichita Girl tells Story of Red Cross Experiences: Helen Deming on Clubmobile Duty in England-Dotes on Real-egg-with-shell-around-it; Loves Her Duties Abroad," Helene Deming, Box 2, Folder 6, Clubmobile Service Collection.

${ }^{9}$ Elizabeth "Bettie" Walters to Mr. and Mrs. Aaron Walters, 25 June 1944, Walters Family Collection.

${ }^{10}$ Petesch, War Through the Hole of a Donut, 84.
} 
However, other women had much stronger feelings about being asked to serve Black soldiers. Anne Ferguson's clubmobile route included a "colored" base while in the UK, and she commented, "The darky soldier [...] looks ridiculous in uniform, he is superstitious, nervous, and fanatically anxious to get home." Anne went on to call one of the men a "slave" with a "gentle but dumb expression on his face" as she described the other soldiers at this "colored" camp assisting the women with vehicle maintenance and other chores. Significantly, Anne did not comment on whether or how she served the Black soldiers, but rather how they served her and the other women. Anne's descriptions of the Black soldiers she encountered demonstrate not only her racism, but also her discomfort at being asked to serve Black soldiers who she felt were beneath her. Indeed, her account suggests that she served only the camp's white officers, who "were a fine bunch, as they would naturally have to be."11

Overall, clubmobilers' descriptions of white soldiers remained consistently positive throughout the war, even when those men were less than their best. As Elma Ernst recalled, "We saw 'G.I. Joe' $[\ldots]$ when he was dirty and unshaven, when he was cold and hungry, when he was wounded." 12 Virginia "Ginny" Billingsley described meeting both new units fresh off the boat and combat veterans fresh off the lines, "[a]nd there was a world of difference in them. They were essentially the same — just babies, most of them — but you could tell by looking at their faces which were coming + which were thru. $[\ldots]$ the boys they see go + the ones who come back aren't the same as we see here. And if only the home folks could see them here, they'd understand them so much better." 13

\footnotetext{
${ }^{11}$ Boy, "The Experiences of One American Red Cross Clubmobiler," 104.

${ }^{12}$ Fay, "Through a Donut Hole," Chapter 1.

${ }^{13}$ Virginia "Ginny” Billingsley to Mrs. R.S. Billingsley (mother), 28 June 1945, Virginia Billingsley Guerriero, Box 2, Folder 8, Clubmobile Service Collection.
} 
Sometimes, clubmobilers had more experience of war than the men they were serving; Elizabeth "Liz" Richardson commented, "We are veterans, compared with our men." ${ }^{14}$ Eloise "Ellie" Green recalled serving a unit that "had only been in France two days [...] They wanted to know all about France, what the useful phrases were, and for the first time in our French lives we could tell someone else about cigarettes pour pappa, how to acquire eggs, etc." 15 While there was a certain satisfaction in being able to impart some wisdom to the soldiers, the women could not help but dread what awaited these innocent youths. Liz reflected, "They are so young and have so far to go yet, but we try not to think of that, although comparisons are unavoidable."16

Though the women often had more experience than the men they served, newly arrived soldiers did not always recognize clubmobilers' wisdom. Mary Small explained that protocol demanded that the women ask permission before serving, and near Christmastime, one newly arrived captain refused: "'I'M [sic] afraid it might upset the order of things. Anyway the men are going to have a hot dinner tomorrow!!' Of all the [...] stinkers. I wish you could have seen thecrestfallen [sic] expressions on thosefaces [sic] which had suddenly lighted up at our arrival. When I think of how officers $[\ldots]$ who have been over here a while knock themselves out to have their men served, I can't help feeling that that captain has a lot to learn." Mary's crew understood how much their wares would mean to the men, and they found a way to circumvent the captain: "I was boundthe [sic] men weren't going to havenothing [sic] for our visit, so we set the boxes of doughnuts and several packages of cigarettes andgum [sic] down on the ground

\footnotetext{
${ }^{14}$ Madison, Slinging Doughnuts for the Boys, 101.

${ }^{15}$ Green, "Journal," 33.

${ }^{16}$ Madison, Slinging Doughnuts for the Boys, 103.
} 
andbeat $[\mathrm{sic}]$ it. ${ }^{, 17}$ In this case, the clubmobilers had a better understanding of the soldiers than their own commanding officer, for they had been in the war zone for much longer than he had.

The captain's refusal to allow Mary and her crew to serve demonstrated that strict gender roles and hierarchies were impractical and even potentially detrimental in the war zone. Indeed, officers who had more experience with clubmobilers often recognized both their capabilities and their wisdom, sometimes allowing the women great freedom in carrying out their duties. Their flexibility stood in sharp contrast to the rigidity of newly arrived soldiers, who were more likely to fall back on the traditional gender hierarchies that disregarded women's opinions. However, the women often circumvented these expectations, as Mary's crew did: they did not verbally contradict the officer, nor technically disobey him by leaving supplies without actually serving, but still did what they could to raise the men's spirits.

A "'gift from heaven"”

However, most soldiers appreciated the women's efforts. ${ }^{18}$ Frontline soldiers were especially grateful for a visit from a clubmobile, but rear echelon troops and indeed most soldiers were thrilled at the opportunity to talk to an American woman. As scholar Claudia Hagen argues, clubmobiles were "one of the most remembered services, from the soldiers" viewpoint." ${ }^{\text {19 }}$ Indeed, many military commanders recognized the importance of clubmobiles to troop morale. Historian James H. Madison finds that when War Department officials considered cutting half the food supplies sent to Europe for Red Cross use, "Army officers in France quickly protested that Red

\footnotetext{
${ }^{17}$ Mary Churchill Small to "everyone," 27 December 1944, Folder “MCS Letters from Europe [1]," Papers of Mary Churchill Small.

${ }^{18}$ Section title: Frances Potts, "My First Week of Clubmobile, or Why did I ever Leave Home," Mary Claire Murtha Henkel, Box 3, Folder 10, Clubmobile Service Collection.

${ }^{19}$ Hagen, American Women During World War II, 208.
} 
Cross coffee and doughnuts were essential contributors to army morale and stymied the proposed cutback." 20

However, it quickly became apparent that the women, not the coffee and donuts, were the real attraction for soldiers. One unit served by Beatrice "Beatie" Bogart's crew "claimed our visit was a 'gift from heaven,"” while a New York Sun reporter commented, "The Red Cross girls have crossed the Rhine and the G.I. Joes are saying 'God bless 'em.",21 This enthusiasm was clearly for the women themselves, not their wares. Patricia Maddox recalled, "The boys are so glad to see us here, as well as surprised. They just want to stand and look at us and listen to us talk.",22 Even soldiers who had not had a warm meal in weeks were often more interested in the women than the donuts and coffee. Newly liberated POWs told Elma Ernst, "You don't have to bring donuts-just talk to us." Even though these men were "unfed" and "haggered [sic]," they valued above all the chance to hear a female voice speaking American English. ${ }^{23}$ The women of Group $\mathrm{C}$ had a similar experience serving 3000 POWs: "They gasped when they saw American women - then they wept — they shook our hands - they crowded around the Clubmobiles for autographs - they tried to smile and tears rolled down their dusty faces (and ours!)." ${ }^{24}$ The women were real, tangible symbols of America and of their freedom.

A visit from a clubmobile allowed soldiers to forget, for a moment, that they were soldiers; the Red Cross reported that a GI talking to a clubmobiler "somehow or other ceases to be the serial number on a dog tag and once again becomes Johnny Jones of Atlanta, Georgia, or

\footnotetext{
${ }^{20}$ Madison, Slinging Doughnuts for the Boys, 181.

${ }^{21}$ Potts, "My First Week of Clubmobile," and Judy Barden, "Red Cross [...] G.I. Joes Say 'God Bless 'em,'” New York Sun, March 26, 1945, Nancy Bastien Chase, Box 1, Folder 11, Clubmobile Service Collection.

${ }^{22}$ Patricia Maddox to her parents-in-law, 18 September 1944, Patricia Maddox Collins, Box 2, Folder 1, Clubmobile Service Collection.

${ }^{23}$ Fay, "Through a Donut Hole," Chapter 20.

${ }^{24}$ Morgan, The Clubmobile, 158.
} 
Sammy Smith of Sioux City, Iowa. ${ }^{, 25}$ This was the magic of a clubmobiler, and soldiers were incredibly grateful to her for it. One soldier wrote to Anne Ferguson, "it would be hard for me to say $[\ldots]$ how much I really enjoyed being with the group. It was almost like not being a soldier at all." ${ }^{26}$ Many a GI eagerly volunteered to help on the clubmobile; Mary Small commented, "The boys just couldn't do enough for us [...] At one point [...] I turned around and discovered that two G.Is were quietly keeping our doughnut trays filled from the boxes and standing ready to do anything when they were needed — all with out [sic] being asked. ${ }^{, 27}$ Other soldiers went out of their way to express their gratitude; the 3254 Signal Service Company sent a thank-you note to Group F signed by every man in the company, filling five full pages with signatures! $!^{28}$

\section{"[A]mateur psychologists"}

Even if they did not directly experience battle, clubmobilers inevitably encountered its aftermath and were expected to provide comfort and support to soldiers trying to make sense of the violence and arbitrariness of war. ${ }^{29}$ This often put them in a delicate position, especially with units that had suffered high casualties; historian Kara Dixon Vuic observes, "If the women were too cheery in their conversations, the men resented their seemingly uncaring attitude. Yet, if the women were too sympathetic, the men 'feel more sorry for themselves. ${ }^{, " 30}$ Finding appropriate ways to interact with soldiers was something the women had to learn on the job. Liz Richardson believed that clubmobilers "have to be amateur psychologists [...] If you only knew what combat does to these boys—not in the physical sense, although that's bad enough—but mentally."31

\footnotetext{
${ }^{25}$ American National Red Cross, "Salute to You: An Informal Report by Chairman Basil O'Connor to Red Cross Workers and Supporters on his Recent Trip to Great Britain, France, and Italy," Box 2, Folder "\#76 Salute to You (informal national ARC report)," Papers of Gretchen Schuyler.

${ }^{26}$ Boy, "The Experiences of One American Red Cross Clubmobiler," 211.

${ }^{27}$ Mary Churchill Small to "family," ND [14 December?] 1944.

28 "To the American Red Cross Attached to VIII Corps," Box 3, Binder 3, Papers of Gretchen Schuyler.

${ }^{29}$ Section title: Madison, Slinging Doughnuts for the Boys, 111.

${ }^{30}$ Vuic, The Girls Next Door, 109.

${ }^{31}$ Madison, Slinging Doughnuts for the Boys, 111-2.
} 
With $20-34 \%$ of casualties from some campaigns classified as "neuropsychiatric," it was inevitable that clubmobilers would encounter men in a fragile mental state as a result of their experiences. ${ }^{32}$ Contemporary psychiatrists were struggling to find ways to explain and treat these record numbers of soldiers with psychiatric problems; untrained clubmobilers had only their own experiences to rely upon in dealing with traumatized soldiers.

Scholar Hans Pols notes that psychiatrists suggested that the men "discuss their feelings with their fellow soldiers or officers" in an attempt to minimize the psychological effects of the war. ${ }^{33}$ However, soldiers often found it easier to confide in women than one another, which was part of the reason the military supported clubmobile service. As a result, clubmobilers not only experienced the hardships of war; they also heard its most intimate details from the men who fought it. In his overview of Liz's experiences, Madison states that soldiers “told her stories not reported in newspapers, stories of combat and brutality, of choices grimly made, of fears and deep regrets — stories that a GI might not write home to a wife or girlfriend, not tell children or grandchildren in the years to come, and sometimes not even confide in a best buddy." ${ }^{34} \mathrm{Liz}$ gained such knowledge at a stationary dock operation in Le Havre. The women of Zone V's clubmobile groups, accustomed to visiting foxholes and digging their own, heard and saw much worse, and knew war even more intimately. Eliza King recalled, "We caught other glimpses of the Front, too-in the eyes and from the lips of those who had moved with it for days and weeks, who looked at us as though we were part of a dream, and then talked as though some dam inside

\footnotetext{
${ }^{32}$ Hans Pols, "War Neurosis, Adjustment Problems in Veterans, and an Ill Nation: The Disciplinary Project of American Psychiatry during and after World War II," Osiris 22, no. 1 (2007): 77, https://www.jstor.org/stable/10.1086/521743.

${ }^{33}$ Pols, "War Neurosis, Adjustment Problems in Veterans, and an Ill Nation," 79.

${ }^{34}$ Madison, Slinging Doughnuts for the Boys, xi.
} 
had suddenly been broken. ${ }^{35}$ Though they may not have directly experienced combat, clubmobilers were more familiar with war than anyone except the soldiers themselves.

A visit from a clubmobile provided soldiers with the opportunity to begin processing their experiences. As Jean Hemingway explained, "Sometimes we have served men just off the lines, looking tired, worn and bedraggled. That's the time when talking is good for the soul. It helps to get some of the terrible things which have happened to them off their minds." ${ }^{36}$

Clubmobilers made the men feel safe, not only from physical danger, but also from judgement or ridicule; they did not have to be afraid to share their feelings with the women. Indeed, Mary "Chichi" Metcalfe found that, "Once they started talking it was difficult to get them to stop."37 Even soldiers unwilling to confide in friends needed little urging to share their trauma with the women, as Patricia Maddox discovered:

As we idled at the table over our empty plates, something (I suspect Betty's soothing influence) broke him of his aggressiveness. Instead of wolfing and spouting noisily, he suddenly started talking quietly and seriously of some of his experiences in the war. [...] the day before he had watched 14 of his buddies being removed from a tank. They were just charred bodies, having been burned alive inside their tank. The boy was desperately trying to be calm. He said that he had to hang onto-literally, hang onto- -his senses. His boisterous, show-off attitude of the morning had been pure panicky bluff. ${ }^{38}$

Unfortunately, the women had not been prepared for these confidences.

Hearing war stories took a toll on the women that most soldiers failed to recognize. As one newspaper remarked, "the GIs know they can dump all of their troubles in her lap." ${ }^{39}$ While this made the soldier feel better, it only added to the clubmobiler's stress. Soon after D-Day,

\footnotetext{
${ }^{35}$ Morgan, The Clubmobile, 79.

36 "Girls, Doughnuts and Coffee Brighten G.I.s Life in Germany," Parade Rest, July 25, 1945, Jean Hemingway Hackleman, Box 2, Folder 9, Clubmobile Service Collection.

${ }^{37}$ Rexford, Battlestars \& Doughnuts, 105.

${ }^{38}$ Patricia Maddox to unknown recipient, 1 December 1944, Patricia Maddox Collins, Box 2, Folder 1, Clubmobile Service Collection. Original emphasis.

${ }^{39}$ Carlyle Holt, ““10,000 Guys Are Just as Nuts About Josie as I Am,” Daily Globe, Feb. 11, 1944, unlabeled folder, Papers of Mary Churchill Small.
} 
Gretchen Schuyler intended to spend a relaxing afternoon, "But who should arrive, but a young Lt. who piloted a glider into France. We sat and drank Scotch while he got off his chest many details of the 'do'. He has now gone and I almost feel as though I had been there myself.All [sic] my relaxing was for nothing,as [sic] I just get worn out living their experiences with them." ${ }^{40}$

Though many clubmobilers had similar experiences, such detailed descriptions of soldier confidences are rare. Newspapers and other sources for public consumption provided only vague statements about clubmobilers being good listeners, and memoirs written years after the war contain similarly general statements, suggesting that the specifics of these stories have been lost over time. Letters are more descriptive on soldier confidences, but they too rarely contain graphic details; such omissions are one example self-censorship, as the women did not want to expose their loved ones to the horrors of war that they faced on a daily basis. This reticence meant that clubmobilers could share the burden of soldiers' confidences only with one another.

\section{"[E]verybody's girl friend"}

Notwithstanding the emotional and physical stresses of war, clubmobilers were also in a rather unique position as the few women among thousands of men. ${ }^{41}$ One clubmobiler recalled, "At night, if anybody was free from cooking or serving, there were invitations galore to dances, parties-the inevitable 'we do so want an American Girl there!"’42 As a result, Vuic notes that most Red Cross women saw dating as part of their job and spent most of their free time with soldiers, even when on leave. ${ }^{43}$ While they often enjoyed themselves, clubmobilers also felt a

\footnotetext{
${ }^{40}$ Gretchen Schuyler to Aunt Ede, 11 June 1944.

${ }^{41}$ Section title: "The GIs," Sinker, Sept. 15, 1944.

${ }^{42}$ Morgan, The Clubmobile, 178.

${ }^{43}$ Vuic, The Girls Next Door, 83. For example, Anne Ferguson frequently described parties or dinner with soldiers, even while on the Continent. While on leave in Cannes, France, Anne "took pity on a forlorn Captain [...] and went to the movies with him," then "dined with Generals Doran and Kibler" that evening. Similarly, Mary Small recounted dinner and dancing with at least two different soldiers while on leave in the French Riviera. Boy, "The Experiences of One American Red Cross Clubmobiler," 208, and Mary Churchill Small to "everyone," 10 June 1945, Folder “MCS Letters from Europe [3]," Papers of Mary Churchill Small.
} 
certain obligation to socialize, for it was another opportunity to raise soldiers' morale. Mary Small attempted to explain the pressure she felt to spend free time with the men: "So often I feel that it is part of my job to go with any G.I. to whom it would mean something [...] then I realize once again that there is a limit to everything, including Christian charity!"44 Though she knew that she did not have to accept every invitation, Mary highlighted the difficulties of saying no, especially because she, and the soldiers, considered it part of her job.

The pressure to accept such invitations was enhanced by soldiers' view of a clubmobiler, as reported in the clubmobile newspaper: “'She's everybody's girl friend [sic]. She's American Red Cross!" "45 As "everybody's girlfriend," the women were expected to attend parties and socialize whenever possible. Though some clubmobilers genuinely enjoyed such evenings and formed close friendships with soldiers, the social pressure and expectation that they be available for dates cannot be ignored. Indeed, Eva Christensen recalled frankly that while in the UK, socializing "gradually got to be a little too much. [...] After all, we had worked all day making doughnuts, serving coffee, making men happy. I did not need the pub." ${ }^{46}$

Some soldiers took the idea of a "Red Cross girlfriend" far more seriously than the women intended. In the summer of 1945, Mary Small reported offhandedly, "Monday afternoon I went for a walk with Fred and got proposed to-I really shouldn't be so flip about it, but that's the way I feel $[\ldots]$ mostly you can stall them off before they get to the proposing stage $[\ldots] \mathrm{Oh}$, me, it's all part of the job I guess." ${ }^{47}$ This was not an isolated occurrence; when a soldier friend unexpectedly proposed to Nathalie Fallon, she "turned and fled," unable to think of a polite way

\footnotetext{
${ }^{44}$ Mary Churchill Small to "family," 9 July 1945, Folder "MCS Letters from Europe [3]," Papers of Mary Churchill Small.

45 "The GIs," Sinker, Sept. 15, 1944.

${ }^{46}$ Johnson, I Too Shall Wear Purple, 174.

${ }^{47}$ Mary Churchill Small to "family," 9 August 1945, Folder "MCS Letters from Europe [3]," Papers of Mary Churchill Small.
} 
to refuse. Several months later, Nathalie reported angrily that the same soldier had proposed to her best friend, who accepted; they were married in New York in early 1946, soon after returning home. $^{48}$ These incidents indicate the difficulties of clubmobilers' position: they had to be friendly and companionable with the soldiers, yet the men might take their friendliness for something more. Additionally, any affection soldiers felt for clubmobilers might not be based on the women's individual qualities, but rather a more impersonal infatuation; thus, the same soldier might propose to two members of the same crew when the first turned him down. ${ }^{49}$ ${ }^{66}$ Dear Donut-girl"'

The image of Red Cross women as "everybody's girlfriend," as well as the paradoxically intimate yet impersonal nature of their interactions, is also apparent through correspondence between soldiers and clubmobilers. ${ }^{50}$ Unfortunately, many clubmobilers, like soldiers, did not keep most of the letters they received. As such, it is difficult to estimate how many men wrote to clubmobile women, and how often the women responded. However, the examples that remain indicate that soldiers wrote to clubmobilers quite often, and that responses did come, though not as frequently as the soldiers would have liked.

Since the American Civil War, letters to and from soldiers have been an integral part of the American war experience. ${ }^{51}$ Especially during the Second World War, government officials and advertisers recognized the importance of mail to the soldier's morale. Historians Judy Barrett

\footnotetext{
${ }^{48}$ Chadwick, "Beyond the Lightline," 106, 145-7, 152.

${ }^{49}$ Most socializing between clubmobilers and soldiers was merely casual dating; however, there are also several instances of more prolonged romantic entanglements. Though it is often difficult to ascertain just how serious such relationships were, Nathalie Fallon gives perhaps the most candid description of conditions: "To tell the truth, we are sick of the sight of men and as for sex, there just isn't any. [...] There isn't any privacy, so such a thing as a hot date is impossible. [...] But there isn't a girl in our unit who hasn't fallen hard for some guy by this time." Chadwick, "Beyond the Lightline," 89. In fact, several clubmobilers, including Anne Ferguson and Rosie Langheldt, met their future husbands during their service, and weddings were not uncommon in the summer and fall of 1945.

${ }^{50}$ Section title: Private First Class W.A. Macrides to Mary Small, 28 May 1945, Folder "To MCS from Europe, 1944-45 [1]," Papers of Mary Churchill Small.

${ }^{51}$ David M. Henkin, "Precious as Gold: Mobility and Family in the Gold Rush and Civil War," in The Postal Age: The Emergence of Modern Communications in Nineteenth-Century America (Chicago: University of Chicago Press, 2007), 137-47.
} 
Litoff and David Smith highlight that during World War II, "popular magazines published numerous articles on how to write a good letter," and various groups organized letter-writing campaigns on the US home front. ${ }^{52}$ Historian Martha Hanna asserts, "almost every soldier insisted that nothing mattered more to his morale than the regular receipt of letters from home."53 While letters to and from home helped the soldier maintain his civilian identity as a son, husband, and/or father, correspondence with clubmobilers served a similar yet unique function, allowing her to again affirm the soldier's individuality, while also providing him with the opportunity to continue to confide in her. When they confided their war experiences to clubmobilers, soldiers sought recognition of their individual experiences as soldiers, allowing them to begin accepting these experiences and integrating their identity as a soldier into their overall identity.

Some men used letters to continue their verbal banter with the women, who were often asked to stir the coffee with their finger so that soldiers wouldn't need sugar. ${ }^{54}$ One soldier wrote to Mary Small, "Hello Honey! [...] I suppose you have a sneaking feeling like I'm being a little fresh in my first letter to you, but hon! I have to write what I feel inside, I hope you don't dislike me for it." ${ }^{, 55}$ While some lovesick soldiers acknowledged that their feelings might be due to the fact that they had not seen an American woman for months, others assured clubmobilers that it was their charm and personality the men loved. Such assurances were often belied by the cursory nature of their interactions. Private Norman Hittman wrote to Mary, "I told Joe how much I'd

\footnotetext{
${ }^{52}$ Judy Barrett Litoff and David C. Smith, “'Will He Get My Letter?': Popular Portrayals of Mail and Morale During World War II," Journal of Popular Culture 23, no. 4 (Spring 1990): 24.

${ }^{53}$ Martha Hanna, "War Letters: Communication between Front and Home Front," 1914-1918 Online: International Encyclopedia of the First World War, last modified October 8, 2014, https://encyclopedia.1914-1918online.net/article/war_letters_communication_between_front_and_home_front.

${ }^{54}$ This comment was so common that the clubmobile newspaper described it as, "the old line, 'Just stick your finger in the coffee to make it sweet." "C.O.F.F.E.E....G.R.O.U.N.D.S," Sinker, Feb. 2, 1945.

${ }^{55}$ Soldier "Lee" to Mary Small, 11 August 1945, Folder "To MCS from Europe, 1944-45 [2]," Papers of Mary Churchill Small.
} 
like to court you [...] Do me a favor Angel, tell me about yourself. All I know is that you are Mary Small of the A.R.C. and you hail from Boston."

Similarly, many letters acknowledged that a clubmobiler may not remember the writer, since he was one of hundreds of men she met in a day. Private First Class W.A. Macrides began his letter, "Dear Mary, Perhaps I should have said, 'Dear Donut-girl' [...] By the time you reach this point you are probably scratching your pretty head and wondering what kind of a 'nut' is responsible for this silly bit of writing." 57 Macrides was no "nut," but one of many who wrote such letters to clubmobilers. Another commented, "I know you never expected to hear from me. In fact, I hardly believe you will remember me." 58 Though they felt silly or awkward and often recognized that the clubmobiler was unlikely to remember them, soldiers continued to write; in fact, some wrote frequently, creating a correspondence with a woman they had met only once.

Letters gave a soldier a way to continue confiding in the women, even after they had left his camp, and to share his experiences with an audience who would actually understand them, as opposed to loved ones at home who had no idea what he was facing. In a letter to Mary, Major Werner Moore reflected, "Why do I write junk like this to you-well I guess I figure you might understand." ${ }^{, 59}$ The importance of this mutual understanding and the outlet it provided for soldiers cannot be understated; another soldier, writing from the hospital, closed his brief letter by explaining, "I'm afraid this is going to have to be a short letter for its [sic] something of a strain to write." ${ }^{60}$ Despite the strain, he chose to write a letter to Constance "Connie" Fagan explaining his situation. From the tone of the letter, it appears that he had corresponded with her

\footnotetext{
${ }^{56}$ Private Norman Hittmann to Mary Small, 17 March [1945], Folder “To MCS from Europe, 1944-45 [2]," Papers of Mary Churchill Small.

${ }^{57}$ Private First Class W.A. Macrides to Mary Small, 28 May 1945.

${ }^{58}$ Boy, "The Experiences of One American Red Cross Clubmobiler," 150-1.

${ }^{59}$ Major Werner Moore to Mary Churchill Small, 11 December 1944, Folder "To MCS from Europe, 1944-45 [2]," Papers of Mary Churchill Small.

${ }^{60}$ Pfc. John R. Depper to Connie Fagan, 3 February 1945, Constance Fagan Russe, Box 11, Folder 5, Clubmobile Service Collection.
} 
before, though he doesn't seem to have been a close friend. Despite this rather tenuous connection, Connie provided him with an outlet to explain what had happened to him and to confide that he was anxious to rejoin his unit. Perhaps he was not comfortable sharing such feelings with his family, who could not understand his connection to his unit; indeed, perhaps he had not even told his family that he had been wounded. Whatever the case, he clearly valued the opportunity to confide in Connie, in spite of the physical difficulties of doing so.

Clubmobilers' letters to soldiers were another contribution to the men's morale. For example, one soldier wrote to Anne Ferguson in February 1945, "I was real glad to get your Christmas card — the fact that I just got it isn't important, what makes me feel so good is being remembered by someone I liked very much. Several times when I have thought of you, I would think of writing you, but each time I would decide that you had probably forgotten who I was, because you meet and become friends with so many fellows. To find that you haven't forgotten me-as I said before, makes me feel very good. ${ }^{, 61}$ Even a relatively impersonal Christmas card, received a month and a half late, reassured this soldier that he was not lost in the sea of olive drab to which he belonged; he was an individual, and someone other than his own loved ones had recognized that. This was one of the clubmobilers' skills: to make each man feel important and seen as an individual, not merely one of thousands of cogs in the war machine.

It is difficult to say how often the women responded to the correspondence they received, but sending Christmas cards to soldiers was an aspect of a clubmobiler's job. In September 1943, the clubmobile newspaper announced a contest for artwork to be placed on "innumerable Christmas cards for Clubmobilers to send their GI friends who have registered during the year in

\footnotetext{
${ }^{61}$ Boy, "The Experiences of One American Red Cross Clubmobiler," 204.
} 
the State or KP books. ${ }^{962}$ In early December, each woman would spend hours addressing these "innumerable" cards. Interestingly, this idea was initially proposed by a clubmobiler, not a male official at headquarters, indicating how much the women took their assignment to heart. ${ }^{63}$

Clubmobilers understood the importance of mail to soldiers because they too highly valued correspondence. Hanna highlights that, "Home-sickness [...] was temporarily eased by the arrival of [mail] from home. ${ }^{" 64}$ Mail offered clubmobilers and soldiers the opportunity to remain connected to their families and to momentarily escape the war. Gretchen Schuyler told her family, "Letters from you people are what helps to keep me going." ${ }^{, 65}$ As clubmobilers moved across the Continent, mail delivery became increasingly unreliable. Gretchen lamented, "My mail has not reached me for ages. It is an anti-morale problem,too. [sic] Our Group has gone for three weeks and a month at a time with no letters. It sure gets us down. ${ }^{, 66}$ Soldiers and clubmobilers alike felt isolated and lonely when mail was scarce, again giving clubmobilers firsthand knowledge of the soldiers' experience; their own efforts to provide correspondence to the GIs demonstrates their dedication to their job.

By writing to soldiers, clubmobilers sacrificed even more of their scarce free time to maintaining soldiers' morale. When they could have been writing to family or friends, the women took time to respond to the men's letters, letting them know that someone cared and understood what they were facing. This was another instance in which clubmobilers' job took over every aspect of their lives. Mail to a soldier represented a connection to the real world, a reassurance that he was not forgotten; clubmobilers, separated from their own families and thrust

\footnotetext{
62 "Christmas Card Contest Announced," Sinker, Sept. 29, 1943. Each clubmobile carried a state book in which soldiers could sign their name, unit, and hometown in hopes of connecting with friends from home.

${ }^{63}$ Petesch, War Through the Hole of a Donut, 80.

${ }^{64}$ Hanna, "War Letters."

${ }^{65}$ Gretchen Schuyler to Col. Philip Lansing Schuyler, 30 April 1944, Box 1, Folder 1944 [2], Papers of Gretchen Schuyler.

${ }^{66}$ Gretchen Schuyler to "family," 4 October 1944.
} 
into the environment of war, felt much the same way. But while a letter from a clubmobile woman could brighten a soldier's day, his letter to her, confiding his fears or sharing the news that he or a friend had become a casualty of the war, was yet another aspect of her work.

\section{"[S] mile, if it kills you"}

Because they were there to keep up soldiers' morale, clubmobilers were expected to be cheerful no matter what, an exhausting prospect. ${ }^{67}$ Angela "Angie" Petesch commented, with a tone of slight exasperation, "Don't know what makes us so tired. Partly it is having to be so darn social all day long. ${ }^{68}$ Unsurprisingly, clubmobilers became fed up with soldiers' attention. Gretchen Schuyler complained, “I don't want to see masses of people as I am tired of being cheerie [sic] and smiling when I feel like chucking the whole works." ${ }^{69}$ However, no one seemed to recognize that clubmobilers might be affected by their experiences; Chichi Metcalfe commented, "just because we were Red Cross girls, everyone expected that we'd never feel downhearted."70 There was no place for a depressed clubmobiler in the ETO; she must always be ready to brighten a soldier's day, and she had internalized the need to hide her own feelings.

The public image of clubmobilers masked the fact that their job was both exhausting and monotonous. Eliza King commented, “I've never worked quite so hard physically, and on top of that, there's the strain of always being happy and smiling." ${ }^{, 71}$ In addition to being physically and emotionally trying, interactions with soldiers quickly became repetitive. While in Germany in June 1945, Mary Small noted that a clubmobiler was expected to laugh at the stalest of jokes: "I thought if another group greeted us with shouts of 'Does it cost 65 dollars to talk to you?' and 'Do you speak English?' I would start throwing thedoughnuts [sic] instead of howling with

\footnotetext{
${ }^{67}$ Section title: Eliza King, "Variations on a Theme in C \& D," Sinker, Feb. 2, 1944.

${ }^{68}$ Petesch, War Through the Hole of a Donut, 119.

${ }^{69}$ Gretchen Schuyler to Aunt Ede, 11 June 1944.

${ }^{70}$ Rexford, Battlestars \& Doughnuts, 70.

${ }^{71}$ Eliza King, “A Doughgirl's Life,” Sinker, Sept. 29, 1943.
} 
laughter as if it were the funniest thing I'd heard in weeks and coming back with one of our standard list of bright sayings of clubmobile girls." ${ }^{, 72}$ No matter how repetitive the joke or how tired the woman, a clubmobiler must always be ready with a smile. Eliza advised in The Sinker, "Your back aches so and you're in a daze from looking down at canteen cups. Your face aches from smiling and your throat hurts from talking. But pick up your feet gal and smile, smile, if it kills you, 'cause they're more American soldiers come to fight a war-somebody's sweetheart or husband or father. You may have seen millions like him but you stand for home to him, so pick up your feet and smile." ${ }^{.73}$ This was the heart of her mission: to remind a soldier that someone cared about him, not as another faceless soldier but as a husband or a father, a wisecracker or a poet, even as she developed an impersonal "list of bright sayings" from which to draw.

The holidays were especially difficult for anyone serving overseas, but, as usual, the women had little time to indulge their feelings. In December 1944, the new Director of the Clubmobile Department in Great Britain admonished the women, "For many of us it will be the first Christmas away from home, and for some of us the second; but we must all keep our eye on our one big objective — untiring service to our troops.."74 There was no room for personal feelings; a clubmobiler's main (indeed, only) concern should be the soldiers she served. Reflecting this philosophy, Elma Ernst wrote on her first Christmas in the ETO, "We too are thousands of miles away from home, perhaps a bit homesick, and admit we have never worked so hard in our lives, but this Christmas will be one we will all remember as the happiest and most gratifying one we have ever spent.." ${ }^{, 75}$ Ignoring their own homesickness, clubmobilers worked extra hard to brighten soldiers' spirits around the holidays. Mary Lou(ise) Pearce recalled, "The Army asked if it was

\footnotetext{
${ }^{72}$ Mary Churchill Small to "everyone," 10 June 1945 . The $\$ 65$ joke referred to the fine soldiers would incur for fraternizing with German women.

${ }^{73}$ King, "Variations on a Theme in C \& D."

${ }_{75}^{74}$ S. Keene Mitchell, Jr., "Christmas Greeting from Mr. Mitchell," Sinker, Dec. 23, 1944. Original emphasis.

75 "Clubmobilers Spend Busy, Memorable Christmas," Sinker, Jan. 6, 1944.
} 
possible for us [Group $\mathrm{H}$ ] to get do-nuts to every single man in the XX corps during Christmas week. The strength of the Corp at that time was 200,000 men. [...] The machines ran around the clock. ${ }^{, 76}$ Feeding an entire corps in a week was a tall order even for a clubmobile group, yet Group $\mathrm{H}$ took on the task willingly.

Adding more stress to the season, some clubmobilers could not help but ponder the moral implications of what they saw during their holidays overseas. Mary Small wrote to her family,

at home you dropped your money in the Salvation Army pot, did your bit for the few people whose Christ-mas you knew would be meagre, figuring that if everyone did the same noone [sic] would be forgotten entirely, andwentsmugly [sic] home [to] celebrate; over here you know that thousands of civilians not only are not feasting but are actually starving and homeless, yet their own countrymen have no facilities for helping them andAmerica [sic] has her hands full winning the war; as to our own soldiers, well, it's no use dwelling on how many of them spent the day wading in mud andblood [sic]; [...] for everyone to whom we were able to bring thesmallest [sic] note of cheer there were so many who had no room in their thoughts for anything but hate and misery. ${ }^{77}$

These concerns compounded Mary's homesickness, making the holidays even more stressful; however, she could not dwell on such misgivings, especially in front of the soldiers.

The difficulties of their life were apparent to clubmobilers; The Sinker noted, "Everyone who is in Red Cross work over here, and everyone who knows about our work, will agree that long hours, working with dozens of people around, meeting hundreds of others during the day, mean an emotional adjustment., ${ }^{, 78}$ Clubmobilers also recognized that their job required a certain temperament. Jane Phillips explained to her mother, “This just isn't a job for a person who is slow in any way for so much of it is hectic and has to be done on the split second and it isn't a job for a person who is a bundle of nerves for things are always happening, and instead of getting upset over it, you just have to remain cheerful and retain all the senseof [sic] humor you have." Jane had little patience for a crewmember who treated a mishap with the donut machine as an

\footnotetext{
${ }^{76}$ Hart, "This is the Way it Was," 39.

77 Mary Churchill Small to "everyone," 27 December 1944.

78 "Everyone Who is in Red Cross Work Over Here."
} 
unfixable catastrophe, and actually sent the woman away while she fixed the problem herself. ${ }^{79}$ Clubmobilers had to adapt to quickly changing situations and unexpected problems, both large and small; if they could not keep calm, they were a detriment to their crew and the soldiers.

Some women were unable to make the required "emotional adjustment." After only two months on the Continent, Gretchen Schuyler reported that a member of Group F was "on the way home with 'War Exhaustion'., ${ }^{80}$ In an extreme case, it appears that one woman was so overwhelmed by and unprepared for clubmobile life that she committed suicide while working in the UK. Gretchen wrote to her family, "[we] discussed Dorothy Stretch at great length. It sure is a shame, and it looks like suciside [sic]. I saw Dot about two weeks ago. She looked 'done in' and was very depressed then. She just wasn't strong enough for the Clubmobile life." ${ }^{81}$ However, such stress went unrecognized by the Red Cross.

Even today, scholars of the psychological effects of war usually focus on soldiers, though clubmobilers' experiences demonstrate that the mental strains of living in a war zone also affect those not directly involved in combat. Recent studies have found that the psychological effects of serving in a war zone are a result of the "sense of threat" that these conditions create; Alex Bierman and Ryan Kelty argue, "the influence of threat on psychological problems is independent of serving in a combat role." Indeed, some scholars suggest that such stresses may be more pronounced for those who lack military training. However, the psychological effects of war on civilian noncombatants continue to be ignored and overlooked, even when their experiences closely mirror those of the soldiers they support. Bierman and Kelty highlight that thousands of civilians employed by the US military have been sent overseas to serve in Iraq and

\footnotetext{
${ }^{79}$ Jane Weir Phillips to Mrs. A.L. Weir (mother), 3 June 1944, Jane Weir Phillips Scott, Box 11, Folder 8 , Clubmobile Service Collection.

${ }^{80}$ Gretchen Schuyler to "family," 4 October 1944.

${ }^{81}$ Gretchen Schuyler to "family," 21 September 1943, Box 1, Folder 1943 [2], Papers of Gretchen Schuyler.
} 
Afghanistan since 2001. ${ }^{82}$ They assert that since the end of the Cold War, "Civilian roles [have] also expanded, as civilians were no longer only (or even primarily) tasked with rear echelon support functions; they were now integrated with military units to support the core war-fighting missions of uniformed military personnel.” Like clubmobilers, civilians working for the Department of the Army today were "liable to the constraints and needs of the military system. [...] civilians working with the military in Iraq and Afghanistan assumed a significant amount of risk, even if they did not directly engage in combat operations." ${ }^{83}$ Bierman and Kelty are the first to recognize the similarities between modern noncombatants' experiences and those of the military. Their work lays important groundwork for the study of the psychological effects of war on noncombatants, though they fail to recognize that such experiences are not solely a modern phenomenon. Clubmobilers' experiences are in many ways similar to those of the modern civilians that Bierman and Kelty examine; however, clubmobilers' gender also played a significant role in their experiences, for the prioritization of soldiers' needs over clubmobilers' was based largely on contemporary gender roles.

\section{"That's what I came for"}

Clubmobilers' recognition of the difficulties of their job were often indirect or couched in language designed to minimize their struggles. ${ }^{84}$ While their reticence makes it difficult to gauge the emotional impacts of clubmobile life on the women, it is clear that they rode an emotional roller coaster. Ellie Green described how, "Sally, Georgia, and Pitter [...] made a morale chart with days of the week [in their room...] In this way the casual visitor can observe the soaring and sinking of their spirits over a period of time. Finding the board not high enough to represent their

\footnotetext{
${ }^{82}$ Bierman and Kelty, "The Threat of War," 27-8.

${ }^{83}$ Bierman and Kelty, "The Threat of War," 29-30.

${ }^{84}$ Section title: Gretchen Schuyler to "Katie and all the rest," 19 June 1944.
} 
emotional instability, the girls have used the wall itself for extreme peaks and depressions.." ${ }^{85}$ While the women had some very positive experiences, their "depressions" were also severe. By putting a chart on the wall that any "casual visitor" could see, they broadcasted their triumphs and difficulties, practically forcing others to acknowledge their feelings.

Even when they did mention the challenges of their job, clubmobilers were quick to add that they were not complaining. Bettie Walters told a friend, "This life is something out of a book - it's fatiguing and sometimes difficult both emotionally and physically, but it's good." ${ }^{86}$ The description of Red Cross life as "something out of a book" gave it a certain romance, despite its "fatiguing" and "difficult" aspects. Though she described her job as "a nerve racking [sic] business," Bettie also minimized its difficulties: "It gets tiresome sometimes making small talk with the boys but that is what we are here for so we keep plugging. ${ }^{, 87}$ Similarly, Gretchen Schuyler told her family, "I've worked like Hell, but that's what I came for.I [sic] get pretty depressed [...] sometimes. But who doesn't living in this atmosphere all the time." ${ }^{88}$ Though attributing her emotional difficulties to the war environment allowed Gretchen to mention them, it did not enable her to express her specific struggles or experiences. The sentiment "that's what I'm here for" was used frequently by clubmobilers to justify their sacrifices; the underlying implication that "this is what I signed up for" was perhaps less true, given the lack of adequate preparation the women received.

Clubmobilers' instinct to minimize their own difficulties was a result of their subordination to the needs of the men, as well as the caretaker nature of their role. Caretakers sometimes ignore their own needs in favor of the needs of their subjects. For example, a female

\footnotetext{
${ }^{85}$ Green, "Journal," 58.

${ }^{86}$ Elizabeth "Bettie" Walters to Agnes Bard, ND [July 1943], Walters Family Correspondence.

${ }^{87}$ Elizabeth "Bettie" Walters to Mr. \& Mrs. Aaron Walters, 8 February 1944, and Elizabeth "Bettie" Walters to Mr. \& Mrs. Aaron Walters, 14 April 1945, Walters Family Correspondence.

${ }^{88}$ Gretchen Schuyler to "Katie and all the rest," 19 June 1944.
} 
nurse who served in the Vietnam War recalled, "II felt obligated to say that my experience was not such a big deal compared to the guys over there. Now I realize that it was. I felt obligated to push it aside and say, "Well, look, I was just a nurse and it wasn't so bad.” But it was. It took me many years before I decided that I owed it to myself, that I had the right to say it was stressful. ${ }^{\prime 89}$ Similarly, many clubmobile women acknowledged that soldiers were suffering much worse. Gretchen Schuyler stated, "We know that our efforts were minor compared to the efforts of those actually in the armed services. We were just grateful we could be there and live that life with them, and serve the war effort in our own small way." ${ }^{90}$ Nonetheless, in a less guarded moment, Liz Richardson "wondered in a letter to a friend [...], 'Who takes care of the Red Cross's morale?",91 The soldiers did not seem to realize how difficult it was for the women to hear their confidences all the time. One clubmobiler remarked, "Sometimes, we think the process should be reversed and the soldiers could boost our morale for a change. ${ }^{92}$

Their constant concern for the men took a toll on clubmobilers, though they would rarely admit it. Sharing soldiers' confidences, witnessing their sacrifices, and living alongside them in dangerous, war-torn country made a clubmobiler's life emotionally trying. A depressed, belligerent soldier was simply a human being reacting to the violence and unpredictability of war; a depressed clubmobile woman was useless. She must always prioritize the soldier, hiding any personal difficulties in order to keep his morale high.

The simultaneously intimate and impersonal relationships that formed between clubmobilers and soldiers revealed the inherent contradiction of clubmobiling: while a soldier felt that he could be himself with a clubmobiler, and often shared intimate experiences with her,

\footnotetext{
${ }^{89}$ Norman, "Coming to Terms with the War," 146-7.

${ }^{90}$ Schuyler, "Operational Outline History of the American Red Cross Clubmobile Group 'F,"” foreword.

${ }_{92}^{91}$ Madison, Slinging Doughnuts for the Boys, xii.

92 Deming, "Wichita Girl tells Story of Red Cross Experiences."
} 
he rarely saw her individuality. Rather, she was a pretty face from home, in many ways interchangeable with her crewmates. As one clubmobiler put it, "You aren’t human, really, you're a Red Cross girl. [...] You've got a second front as solid as the one the Yanks have built— the thick, deep you that is Red Cross girl, laid like plywood over your real self that nobody wants to know. You're artificial as all get-out and human as a woman-terribly calloused and never quite callous enough. ${ }^{93}$ As representatives of the average American woman, clubmobilers symbolized warmth and understanding for a soldier, who need not be afraid to share his feelings with her. Yet the women learned quickly that they must never reveal their own misgivings or stresses to the soldier; indeed, beyond knowing her (nick)name and hometown, he was rarely interested in any detail of her life. Even as she transformed the soldier from a serial number to a name, a clubmobiler turned herself from an individual into a Red Cross girl who was expected to witness the hardships of war, both first- and secondhand, and suppress her own needs, or indeed any indication that she was a human being affected by the violence that surrounded her.

Because they provided soldiers with an escape from the war, clubmobilers could never escape their role in it. Their "free" evenings were spent at parties or on dates with the men; they even spent time corresponding with soldiers, raising the morale not only of the men they saw each day but also those they had met only once, months ago, who now saw them as a confidante. As such, clubmobilers were never "off-duty," and had few outlets to express their frustrations and stresses. When writing to friends or loved ones at home, it was difficult for clubmobilers to express their true sentiments; parents concerned about their daughters living in a war zone would be even more worried if they heard tales of violence and death. Unable to escape the environment of war and the sea of soldiers, even while on leave, the women turned to each other

\footnotetext{
${ }^{93}$ Morgan, The Clubmobile, 119-20.
} 
for support, relying on one another's experience and friendship to face the challenges of clubmobile life. 


\section{Chapter 4: Sisterhood: Coping with war}

"It was definitely one of those days today. Everything seemed hard. I am really tired tonight. But everything is all right $[\ldots]$ Things are really going well + we are all having fun together," (Jane) Anne Jack wrote to her husband soon after her arrival on the Continent. ${ }^{1}$ Anne's comments reflect both the difficulties of clubmobile work and the most important way the women met the challenges they faced: together. Especially on the Continent, clubmobilers came to rely on one another, not only to do their job effectively, but also to keep their own spirits up in the midst of the violent, uncertain atmosphere of war. Their shared experiences created a sense of camaraderie among them comparable to a soldier's connection to his unit. Members of individual crews were even more tight-knit, as they spent the majority of their time together and learned to rely on one another both physically and emotionally.

From the camaraderie of being a clubmobiler to the bond between specific crews or individuals, the relationships between clubmobilers were essential to their morale and their ability to do their job well. A tight-knit crew could face anything together, but conflict between the women made the job much more difficult. Though the Red Cross made some efforts to cultivate a sense of camaraderie among the women, they failed to recognize the importance of the bonds that formed between clubmobilers. This ignorance was a product of societal gender norms, which not only privileged male experiences above all else but also devalued female friendship in general. Studies of women's wartime experiences similarly fail to consider women's morale, compounding the general disregard for female noncombatants and recreation workers. Clubmobilers' experiences demonstrate that morale is not merely a military problem,

\footnotetext{
${ }^{1}$ Jane Anne Jack to George Jack, 30 August 1944, Jane Anne McKee Jack, Box 6, Folder 8, Clubmobile Service Collection. Anne Jack was one of the few clubmobilers who was married before her service began. She and her husband, a British soldier, corresponded daily and met up several times, even while she was serving on the Continent. Apparently, the Red Cross regulation about women serving in a different theater than their husbands did not apply if they were married prior to their service.
} 
but rather, one that affects any individual serving in a war zone. Overlooking clubmobilers' camaraderie represents a continued marginalization of their experiences and the importance of their own individual needs.

\section{Official concern (or lack thereof) with Red Cross morale}

To a certain extent, the Red Cross attempted to build camaraderie among its workers. Upon receiving their assignments, Red Cross personnel were given a "Guide for Your Trip," which contained "a few suggestions [...] to help you in making this trip easy and successful." Acknowledging that most recruits had never travelled in a large group or under military supervision and secrecy, the guide attempted to prepare the women for what was to come. Most significantly, the first suggestion was, "Be group-minded": each woman must help others and work for the well-being of the group while representing the Red Cross. ${ }^{2}$ The organization, however, did not anticipate how important camaraderie would become for clubmobile women.

This pre-departure guide was issued to all Red Cross personnel traveling overseas, but the Red Cross also took steps to encourage camaraderie among clubmobilers in particular. In August 1943, the Clubmobile Department began publishing The Sinker, the biweekly clubmobile newspaper that contained information on personnel transfers, news from headquarters, and stories from specific crews. The inaugural issue stated, "Its aim is to help Clubmobilers get better acquainted with one another; to pass on for the enjoyment of all some of the interesting and amusing incidents of Clubmobile life; and to leave you a record, to which you may refer in future years, of the time when 'doughnuts and coffee' (and push-rods!) played a big part in your lives."3 Recognizing that clubmobile life could be remote and isolated, the Red Cross attempted to foster morale among the women by giving them pride in their work.

\footnotetext{
2 “A Guide for Your Trip," Nancy Bastien Chase, Box 1, Folder 10, Clubmobile Service Collection.

3 “The Sinker Makes its Bow," Sinker, Aug. 15, 1943.
} 
Despite interest in building camaraderie among clubmobilers through The Sinker, the Red Cross often made decisions that undermined morale. Gretchen Schuyler confided to her sister, "I find myself so often being afraid to grow the least bit fond of any person or any place,for [sic] as soon as I do I am separated from it.We [sic] just can't have ideas of our own of who we'd like to work with or where we'd like to work." ${ }^{4}$ The threat of reassignment was constant, even for clubmobilers working on the Continent. The Red Cross' disregard of the importance of camaraderie mirrored that of the US military. Scholar Peter Kindsvatter notes that during both World Wars, the American military "followed a destructive policy [...] of putting soldiers who had recovered from a wound or illness in the general replacement pool instead of returning them to their old outfit." This policy resulted in many soldiers going "AWOL to the front," leaving the hospital prematurely to rejoin their old unit. ${ }^{5}$ Though unit and crew assignments were pivotal in maintaining morale, both the military and the Red Cross ignored these personal preferences.

Red Cross officials tried to maintain a hierarchy of authority, admonishing workers not to challenge group leaders; after all, "they didn’t ask for their jobs." ${ }^{.6}$ However, for the most part, clubmobilers had great respect for their female leaders; indeed, it was usually male officials that the women, and The Sinker, mocked. Scholar Lee Kennett noted that World War II-era soldiers "wanted officers $[\ldots]$ who led by example, $[\ldots]$ and who knew their jobs; but they also wanted leaders who knew and cared about the men, shared jokes and hardships with them."7 The same was true of clubmobile women: they largely respected their female group leaders and supervisors because they weathered the hardships of clubmobiling on the Continent with their groups.

\footnotetext{
${ }^{4}$ Gretchen Schuyler to Mrs. C.J. McCarthy, 16 July 1944, Box 1, Folder 1944 [2], Papers of Gretchen Schuyler.

${ }^{5}$ Kindsvatter, American Soldiers, 132.

6 "A Guide for Your Trip."

${ }^{7}$ Lee Kennett, G.I.: The American Soldier in World War II (New York: Charles Scribner's Sons, 1987), 142, quoted in Kindsvatter, American Soldiers, 229.
} 
Officials at headquarters, on the other hand, seemed woefully uninformed. Gretchen Schuyler, captain of Group F, commented, "The 'society dames' in the ARC HQ never follow our doings well enough to rely upon them in a crisis. We ignore them!"8 Kindsvatter asserts, "the frontline soldier came to believe that the people in the rear did not have a clue as to what the combatants were going through and, worse, did not seem to care." 9 The same was true for Gretchen, who believed official ignorance was willful: "big-shots from HQ [...] just seem to hate to see what we put up with.......when they are able to do so little to help us." Though Gretchen had invited several of these "big-shots" to visit her group and experience firsthand the conditions they lived under for months, these visits never occurred. ${ }^{10}$ As such, Gretchen had little respect for Red Cross officials. Because headquarters had little knowledge of field conditions, it was up to Gretchen, as group captain, to ensure that the women had places to sleep, to organize her group's serving schedule and time off, and to take care of the many problems they encountered each day. This was no small feat: "Someday, some of us who have been through the mill may get a chance to tell the handicaps under which we have been carrying on. You wouldn't believe it. We beg, borrow and steal; we make plenty out of nothing; we improvise until you'd think what we made was impossible...but we work."11 Indeed, it was amazing that not only Gretchen's Group F, but all the clubmobile groups, were so successful in carrying out their duties with little official guidance.

\section{Family}

Due in part to this abandonment by headquarters, clubmobilers in the field formed incredibly strong connections with one another. Throughout their letters and memoirs, the word

\footnotetext{
${ }^{8}$ Gretchen Schuyler to Col. Philip Lansing Schuyler, 20 March 1945, Box 1, Folder 1945, Papers of Gretchen Schuyler.

${ }^{9}$ Kindsvatter, American Soldiers, 252.

${ }^{10}$ Gretchen Schuyler to "Katie and all the rest," 14 January 1945, Box 1, Folder 1945, Papers of Gretchen Schuyler.

${ }^{11}$ Gretchen Schuyler to "family," 23 November 1944, Box 1, Folder 1944 [3], Papers of Gretchen Schuyler.
} 
"family" was used frequently to describe coworkers. Indeed, it is striking how often this language was used by various clubmobile women. Based in their shared experiences in the war zone, clubmobile families supported one another, helping each other cope with their experiences.

In a broad sense, this family included Red Cross women as a whole. For example, Elizabeth "Bettie" Walters commented after an air raid, "Funny how you feel you know people so well that you are with during those times. Of course all us [Red Cross] gals whether we know each other or not feel like we are one big family." ${ }^{, 2}$ However, clubmobile families evolved from more than the camaraderie of an air raid shelter. The Sinker unabashedly claimed, "We Clubmobilers have a certain smugness which we hope is not obnoxious to others. At least we have that close feeling of being one big family, sharing our experiences and work and being very happy in having that feeling." ${ }^{, 13}$ This was not mere posturing, nor were officials taking an overly rosy view of the situation. On the contrary, many clubmobilers affirmed the unique bond they shared with one another, especially with their own group and crew.

Always surrounded by military men, clubmobilers came to value the female companionship that only they could provide one another. Describing a crewmate's birthday party, Mary Small commented, "How odd it must seem to the men-hungry gals back home that 13 girls over here would choose to celebrate—in the midst of thousands of men—by having a hen party. ${ }^{, 14}$ Researcher Ana Martínez Alemán finds that female friendships are especially significant for women in male-dominated fields; indeed, one research subject commented, “'all hard science remains quite sexist. Without those women in my daily life I think I would have

\footnotetext{
${ }^{12}$ Elizabeth "Bettie" Walters to Mr. \& Mrs. Aaron Walters, 28 March 1944.

13 "Presentation Dinner for Mr. Momand," Sinker, June 23, 1944.

${ }^{14}$ Mary Churchill Small to "family," 12 March 1945, Folder "MCS Letters from Europe [2]," Papers of Mary Churchill Small, original emphasis.
} 
quit long ago.”" ${ }^{15}$ Martínez Alemán's findings on the importance of female friendships can be applied to clubmobilers, whose camaraderie provided them with an escape from a maledominated environment. The "hen party" that Mary described allowed the women to celebrate female companionship.

The camaraderie of clubmobilers, especially those who served on the Continent, was largely based on experiences that no one else, not even other Red Cross women, would understand. During leave at a Red Cross club in London soon after VE Day, Betty Jane "B.J." Thomas commented, "when I talked to my Red Cross cohorts, I felt quite out of joint." The other women were initially eager to hear about her experiences on the Continent; however, B.J. "didn't get very far without running into stumbling blocks." Her companions asked about the excitement of VE Day, which B.J. struggled to explain had been rather anticlimactic; about the wonderful French food, though B.J. ate rations or in army mess halls most of the time; about how reports of looting must be exaggerated, which B.J. tactfully tried to avoid by devouring her lunch. It was clear that the other women's romantic notions of life on the Continent prevented them from understanding B.J.'s experiences: "By the end of the luncheon they didn't want to hear any more of my answers to their questions. And for the rest of my stay there I feigned complete exhaustion or battle fatigue and gained the solitude, which was what I really wanted." ${ }^{\prime 16}$ Only other clubmobilers, who had shared similar experiences, could understand B.J.'s life on the Continent; anyone else, even other Red Cross women, seemed woefully ignorant and unwilling to hear the harsh realities of life near the front lines.

The term "family" was not used lightly by clubmobilers; their bonds with one another were such that they became as close as, if not closer than, family. In fact, these feelings extended

\footnotetext{
${ }^{15}$ Ana M. Martínez Alemán, “College Women's Female Friendships: A Longitudinal View,” The Journal of Higher Education 81, no. 5 (September/October 2010): 565, http://www.jstor.com/stable/40835719.

${ }^{16}$ Olewiler, $A$ Woman in a Man's War, 167-9.
} 
to actual blood relatives. Mary Small's crewmate Helen "Wally" Wolek wrote to Mary's Aunt Barbara, informing her, "You may not have discovered it as yet but the number of nieces you have is rapidly increasing, and I happen to be one of your newly acquired family [...Mary's cousin Tom] automatically became Cousin Tom to [the] 32 girls [of Group L]! From that moment on, we have become part of the family—Now we are all referred to as Cousin Cece, Cousin Wally, etc." ${ }^{17}$ Clearly, Wally felt that Mary and the rest of Group L were truly family, and had no qualms about writing a letter to someone she had never met to affirm this connection.

The abundance of material available from Group F Captain Gretchen Schuyler allows for an in-depth examination of the bonds amongst this group. Gretchen herself was particularly cognizant of the importance of camaraderie and the women's own morale, and commented often on the happiness and unity of her group. From the beginning, Gretchen recognized the importance of mutual trust between the crews and herself. In April 1944, the newly formed group was assigned to serve an Airborne Division in southern England, which they were supposed to follow across the Channel. This assignment gave Gretchen a chance to get to know the women of Group F before being thrown onto the front lines. She commented, "The girls in the crews are turning out well. I think they like me and trust my decisions. This fact alone is important when we will be going into dangerous areas. I have the utmost confidence in them." ${ }^{\prime 18}$ In addition to their trust in her, Gretchen took pains to create a congenial group environment: "Yesterday $[\ldots]$ we all went to the hotel and each had a double Scotch and then a grand dinner I had arranged a week in advance. It was the first time the entire group has done anything social together as we are all stationed about 30 miles apart. So we dwaddled [sic] over dinner and had a

\footnotetext{
${ }^{17}$ Helen F. Wolek to “Aunt Barbara," 16 February 1945, Folder "MCS Letters from Europe [3]," Papers of Mary Churchill Small.

${ }^{18}$ Gretchen Schuyler to Col. Philip Lansing Schuyler, 15 May 1944, Box 1, Folder 1944 [2], Papers of Gretchen Schuyler.
} 
real nice time. Of course I know each crew pretty well, but the crews haven't had much of a chance to know other crews." 19 By arranging this dinner for the sole purpose of letting the crews get to know one another, Gretchen acknowledged the importance of a positive group dynamic and encouraged the women of Group F to begin thinking of themselves as a family.

Gretchen's efforts to build a Group F community paid off as they crossed the Channel and began serving troops in France. She wrote home proudly, "We have a grand spirit. I have a good bunch. They are thoughtful,kind [sic] to each other and are always willing to put personal desires aside for the good of the others." 20 Their unity and concern for one another made Group $\mathrm{F}$ an effective team that Gretchen loved captaining. She continually made comments such as, "The girls in my unit are grand and I look forward to the future with no misgivings.",21

The women relied on Gretchen, as the head of the Group F family, for guidance in their initial months on the Continent: "We all get low at times. I have had more than half the Group cry on my shoulder already. Kids that never would let things reach that point at home. [...]

Several A.R.C. Clubmobile girls have been invalided home already. My Group has shown the least signs along this line. We have been the most isolated Group since we landed over here. But we all 'love the field' and are thriving." ${ }^{, 22}$ Gretchen also credited the women of Group F with maintaining her own morale: "The girls are wonderful. [...] If it were not for them, I would be discouraged. ${ }^{, 23}$ Clearly, the unity and support that Group F offered one another were essential in their success on the battlefield, allowing them to do their job and keep their own morale high.

\footnotetext{
${ }^{19}$ Gretchen Schuyler to "family," 17 June 1944, Box 1, Folder 1944 [2], Papers of Gretchen Schuyler.

${ }^{20}$ Gretchen Schuyler to "Katie and all the rest," 10 October 1944, Box 1, Folder 1944 [3], Papers of Gretchen Schuyler.

${ }^{21}$ Gretchen Schuyler to Mrs. C.J. McCarthy, 27 July 1944, Box 1, Folder 1944 [2], Papers of Gretchen Schuyler.

${ }^{22}$ Gretchen Schuyler to Aunt Ede, 12 October 1944.

${ }^{23}$ Gretchen Schuyler to "family," 23 November 1944.
} 
The camaraderie amongst Group F was so strong that Gretchen reported that the women hated to be separated for very long: "Two Clubmobiles are away from the Group attached to a Division. They are now crying to get back...as they miss being with the Group!" 24 This was a somewhat unusual attitude; detached service was a common occurrence for clubmobilers, especially when the army was moving quickly across Europe and was therefore more difficult to serve from a single location. Clubmobiles' mobility was one of their main assets, and crews could be on detached service for weeks at a time. The women's objection to this assignment demonstrates the strength of the bonds amongst Group F. These connections were such that even while on leave, Gretchen missed her group: "I have been away from Group F for over 15 days now. That bothers me more than I can say. $" 25$ Though she acknowledged that the break had done her good, Gretchen was ready to get back to her family by the time her leave was over.

Knowing how arbitrarily and suddenly Red Cross reassignments could occur, Group F lived in fear of separation. In September 1944, when they had been on the Continent for just over a month, Gretchen wrote home, "The girls are wonderful. I am horribly attached to them all. They are afraid I may be pulled out for another job, and I am scared they will too." ${ }^{26}$ However, these fears amounted to nothing. When the possibility of a new job presented itself a few months later, Gretchen reported, "I've just had a big job offered me by the ARC. It would require me living in Paris, so I turned it down. I am still a 'field-soldier' at heart, and I'll stick with Group F as long as they'll have me."27

In the winter of 1944-45, the Red Cross began splitting the clubmobile groups in half to cover more ground. Gretchen was devastated by this news: "Right now I am a bit upset as it

\footnotetext{
${ }^{24}$ Gretchen Schuyler to "family," 16 September 1944.

${ }^{25}$ Gretchen Schuyler to "Katie and all the rest," 1 March 1945, Box 1, Folder 1945, Papers of Gretchen Schuyler.

${ }^{26}$ Gretchen Schuyler to "family," 16 September 1944.

${ }^{27}$ Gretchen Schuyler to "Katie and all the rest," 29 December 1944, Box 1, Folder 1944 [3], Papers of Gretchen Schuyler.
} 
looks as though all the Clubmobile Groups will be split up to do a bigger job and cover a wider area. This slays me, as my Group 'is the best'. We love each other and we work well as a team. [...] I have grown fond of the kids and we all hate to seperate $[\mathrm{sic}] .{ }^{, 28}$ The camaraderie of the group was due in part to Gretchen's efforts, and she felt a certain sense of pride in their accomplishments: "I hate the thought of it all, as I love the Group and will feel very lonesome when I am not living with a gang of people. [...] it sure is discouraging when I've worked so hard to have the Group work so well, to now have it busted up. ${ }^{, 29}$ Gretchen reported that following this news, a sense of melancholy pervaded the entire group: "Here we sit like birds in the wilderness waiting for news of our Group split-up to come. We continue to work our usual tough schedule, but our hearts are not in it, when any minute we may all be sent to the far ends of the Continent." She attributed the strength of their connections to their shared experiences: "Our gang has been working together since April $19^{\text {th }}$ [1944]. We have come across as a unit and have had all the experience of the start of things here in one compatable [sic] group. ${ }^{\prime 30}$ To be forced to separate after all they had been through seemed the height of injustice.

Luckily for the women of Group F, theirs was the only clubmobile group that was not divided into two smaller units. In March 1945, Gretchen reported, "All is going well with the Group. We are the last unit to remain intact. We will some day [sic] be Sections 11 and 12. But so far we are still Group F. I am glad. We have done a good job and it is nice to remain as a single unit as long as possible." ${ }^{31}$ Though the Red Cross had planned to divide Group F, the women remained together until VE Day, longer than any other group.

\footnotetext{
${ }^{28}$ Gretchen Schuyler to "Katie and all the rest," ND [26 November 1944?], Box 1, Folder 1944 [3], Papers of Gretchen Schuyler.

${ }^{29}$ Gretchen Schuyler to "family," 2 December 1944, Box 1, Folder 1944 [3], Papers of Gretchen Schuyler.

${ }^{30}$ Gretchen Schuyler to "Katie and all the rest," 5 December 1944.

${ }^{31}$ Gretchen Schuyler to Mrs. C.J. McCarthy, 13 March 1945, Box 1, Folder 1945, Papers of Gretchen Schuyler.
} 
In preparation for the German occupation, the clubmobile groups on the Continent were broken up. Only a week after VE Day, Gretchen was alerted that her group would soon be dissolved, prompting her to write, "I've had enough. The work, as far as organizing, is finished. The Group will be scattered all over Hell and gone. The Group is my major interest, and when that begins to happen, I just as soon be elsewhere [sic]." ${ }^{, 32}$ She pledged to stay as long as her group was intact, but as soon as it split up, she was ready to go home permanently.

A little over a month later, Gretchen reported to Red Cross headquarters in Paris to begin trying to go home. In early July, still waiting for clearance and transportation, she commented

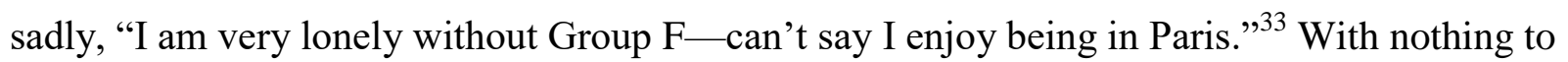
do and alone for the first time in over a year, Gretchen became increasingly melancholy as transportation proved difficult to find. In mid-July, she cabled home, "No transportation until September or October very discouraged." ${ }^{34}$ After the companionship of her Group F family, Gretchen found the solitude almost unbearable.

Though Group F was in some ways unique, in that it remained undivided until the general dissolution of the clubmobile groups in the summer of 1945, the camaraderie and sense of family amongst the women of Group F were in many ways representative. Their unity and willingness to support one another were reflected in the memoirs and letters of clubmobilers from all groups, and their dread of separation was not unusual. Indeed, in recounting their experiences after the war, Gretchen noted, "During the period recorded here we were to feel secure, as we all had a sense of belonging to a particular unit. Every clubmobile group had this same feeling in

\footnotetext{
${ }^{32}$ Gretchen Schuyler to "Katie and all the rest," 17 May 1945, Box 1, Folder 1945, Papers of Gretchen Schuyler.

${ }^{33}$ Gretchen Schuyler to Mrs. C.J. McCarthy, 10 July 1945, Box 1, Folder 1945, Papers of Gretchen Schuyler.

${ }^{34}$ Gretchen Schuyler to Ketrine Schuyler McCarthy [Mrs. C.J. McCarthy], telegram, 16 July 1945, Box 1, Folder 1945, Papers of Gretchen Schuyler.
} 
common." ${ }^{35}$ Group F was an especially tight-knit family, but their camaraderie and pride in their group were common amongst clubmobilers on the Continent.

Though the experiences of the clubmobile groups demonstrate the importance of camaraderie, studies of women's experiences in general rarely mention female friendship. Morris Janowitz and Roger Little note that soldiers' group norms "arise from the larger military environment and from the surrounding civilian society." ${ }^{36}$ Interestingly, societal views of female friendships at the time often portrayed them as far less important than male friendships. Scholar Lucy Fischer finds that because traditional gender roles confine the woman's place to the home, "It is assumed that all nonfamilial relations will be secondary to them." 37 Portrayals of female friendships often fall into various stereotypes that depict them as inferior to male friendships. According to Virginia Curlee Koenig, stereotypes assume "that women tend to mistrust each other ... [and] compete with one another for men," precluding any chance for emotional support or intimacy in female friendships. ${ }^{38}$ The themes of jealousy, mistrust, and competition for male affection in popular portrayals of female friendships exemplify the fact that women's experiences are often understood solely in relation to men.

However, since the late 1980 s, scholars have begun to examine the creation and importance of female friendship. In her study of female friendships formed in college, Ana Martínez Alemán finds that college women's friendships are often more intimate than friendships formed later in life, as a result of the similarities in college women's stage of life and the levels of personal growth and identity formation that generally occur during college.

\footnotetext{
${ }^{35}$ Schuyler, "Operational Outline History of the American Red Cross Clubmobile Group 'F," 25.

${ }^{36}$ Morris Janowitz and Roger W. Little, Sociology and the Military Establishment, $3^{\text {rd }}$ ed. (Beverly Hills and London: Sage Publications, 1974), 94, quoted in Kindsvatter, American Soldiers, 124.

${ }^{37}$ Lucy Fischer, "Girl Groups: Female Friendship," in Shot/Countershot: Film Tradition and Women's Cinema (Princeton: Princeton University Press, 1989), 220, http://www.jstor.com/stable/j.ctt7zv9rz.11.

${ }^{38}$ Virginia Curlee Koenig, "Intimacy in the Marital and Female Friendship Relationships of Women" (Ph.D. thesis, School of Education, University of Pittsburgh, 1983), 36, quoted in Fischer, "Girl Groups,” 219.
} 
Martínez Alemán asserts that female friendships provide women with "a respite from academic stress and anxiety" and serve as forums offering both advice and validation, providing many of the same benefits as clubmobilers' connections. ${ }^{39}$ Because they were operating in a war zone, the strength and benefits of clubmobilers' camaraderie became all the more important to their individual well-being and survival. However, their friendships were far more than mere survival strategies. The war represented a time of personal growth and definition that was in some ways comparable to college: many clubmobilers were abroad for the first time, taking on new responsibilities and facing new expectations. As such, their friendships were not only a result of the difficulties of the war environment, but of their shared experiences of overseas service, both positive and negative, which made the war a defining moment in their lives.

\section{"I wish I could like them"}

Though most accounts of clubmobile service depict a united group of women who take pride in their identity as clubmobilers, they were not without conflict. ${ }^{40}$ Arguments and clashes of personality between the women made clubmobiling more difficult; a cohesive crew and respect for one's coworkers, especially the group captain, were essential to both effectively operating a clubmobile and maintaining a positive attitude. When disagreements arose and were not quickly resolved, they had a detrimental effect on the women's morale. Though descriptions of conflict between crewmates are rare, a few women recount problems within various crews. Such accounts are found primarily in journals and letters written during time overseas and appear only rarely in material written after the war.

Anne Ferguson of Group A, for example, recorded issues with several different coworkers. In one instance, Anne F. reported, "The tenseness which had been growing between

\footnotetext{
${ }^{39}$ Martínez Alemán, "College Women's Female Friendships," 554.

${ }^{40}$ Section title: Jane Anne Jack to George Jack, 4 October 1944, Jane Anne McKee Jack, Box 6, Folder 8, Clubmobile Service Collection.
} 
me and Mary [Pitcairn] finally came to a head and we had a bang-up fight, but now that it is over I think the sailing will be smoother." ${ }^{41}$ This disagreement took place in early November 1944, after Group A had been on the Continent for several months. Anne F. does not specify the cause of this "tension," but it is possible that the stresses of clubmobile life finally boiled over into an argument. This seems to have been the end of it, for neither Anne F. nor their third crewmember, Jane Phillips, reported any further problems between Mary P. and Anne F.

Anne F. also harbored an intense dislike of her group captain. As early as August 1944, Anne F. recorded a trip to Cherbourg, France, where, "We collected mail and talked with both Mr. Nomand and Mr. Clarke about Viki [Harriette "Viki" Atkinson, Group A Captain]. We felt that the time had come for that gal to get set straight. She's too much of a party girl, and Harry [the group supervisor] had to do her work as well as his own." ${ }^{42}$ Anne F.'s disdain of Viki was such that, "I am ashamed to belong to Group A—especially of being connected with our particular Group Captain. ${ }^{, 43}$ This is especially significant, as most clubmobilers "smugly believe that theirs is the best group in the Clubmobile Department." ${ }^{\text {"4 }}$ Anne F.'s shame at belonging to Group A made her job more difficult, as she lacked the pride in her work that characterized most clubmobilers and made them feel that their sacrifices were worthwhile.

It was not only Viki's "party girl” personality that alienated Group A, but also her leadership. As group captain, Viki decided when and where the clubmobiles would be sent. In early September 1944, Anne F. reported, "Viki, our group captain, had been finagling (!) in a most underhanded way, and we are to be transferred to 12th Army Group. The majority of us are very upset to leave our 1st Army friends. It will be hard to make our way with a whole new

\footnotetext{
${ }^{41}$ Boy, "The Experiences of One American Red Cross Clubmobiler," 168.

${ }^{42}$ Boy, "The Experiences of One American Red Cross Clubmobiler," 130. The reference to "Mr. Nomand" is Anne F.'s mistake - she was referring to Don Momand, Director of Clubmobile Operations on the Continent.

${ }^{43}$ Boy, "The Experiences of One American Red Cross Clubmobiler," 127.

${ }^{44}$ Morgan, The Clubmobile, 166.
} 
group. We had just begun to really feel at home." Clubmobilers took pride in "belonging" to certain units, sharing their victories and commiserating over defeats. However, Viki did not seem to realize how attached her group was to $1^{\text {st }}$ Army. Anne F. reported, "Right at the moment we are waiting for Viki to come back from 1st Army. We were to spend two days with them before going to 12th Army Group, but she's been trying to get out of it. She just plain doesn't like them there and apparently the way the rest of us feel makes no difference whatsoever. Lots of us were counting on that time with our friends, and if we don't go it will be a real disappointment." ${ }^{, 45}$ Viki's decision to reassign the group, without their consensus, increased tensions within Group A. Though they adapted to the change and formed connections with $12^{\text {th }}$ Army, several members of Group A would later seize opportunities to reconnect with $1^{\text {st }}$ Army friends. For example, Mary "Chichi" Metcalfe and her crew visited the men of the $1^{\text {st }}$ Army's $49^{\text {th }}$ Anti-Aircraft Artillery Brigade on several occasions, and they "celebrated Thanksgiving [with the $49^{\text {th }}$ Brigade] almost as if we were at home." ${ }^{46}$

Group E experienced similar problems with their group captain, as noted by Anne Jack: “The meeting was about E Group + [Group Captain] Betty Schuller + how we feel she doesn't know what she's doing + is keeping us all in a state of nerves. Everyone agreed on the subject + we composed a letter to headquarters." ${ }^{, 47}$ A few weeks later, Anne J. mentioned, "We're in the midst of changing group captains at the moment. ${ }^{48}$ She did not elaborate, and there is no further mention of the outcome of the situation. However, Anne J.'s comment that these difficulties were "keeping us all in a state of nerves" demonstrates the detrimental effect of such conflicts on clubmobilers' morale. Indeed, scholars Mark Vaitkus and James Griffith assert that a "supportive

\footnotetext{
${ }^{45}$ Boy, "The Experiences of One American Red Cross Clubmobiler," 143-5.

${ }^{46}$ Rexford, Battlestars \& Doughnuts, 67.

47 Jane Anne Jack to George Jack, 4 October 1944,

${ }^{48}$ Jane Anne Jack to George Jack, 16 October 1944, Jane Anne McKee Jack, Box 6, Folder 8, Clubmobile Service Collection.
} 
unit climate cannot be achieved independently of a positive leadership," highlighting the importance of group captains in maintaining group morale. ${ }^{49}$

In addition to issues with her group captain, Anne J. also recorded difficulties with her own crew, which she captained. She complained to her husband, "Ginny + Mac [Helen McGregor] are still driving me nuts. They are such high school children. I wish I could like them. I rather like Ginny, but she carries on rather childishly sometimes. I never can feel close to Mac." ${ }^{50}$ Soon after, Anne J. reported, "I am more or less staying away from the Augusta these days. It's a tremendous relief for me + I think the girls enjoy being on their own. It's more or less of an experiment too, to see if they are any good as clubmobilers without someone driving them." ${ }^{, 51}$ Indeed, Anne J. was skeptical that her crew would be able to operate the clubmobile without her supervision: "Ginny + Mac are supposed to be cooking this morning while I have the morning off. Mac has told Ginny she can manage by herself and to stay upstairs + wash her hair. I know darn well one person alone can't do a good job of making doughnuts, but those girls just don't care. They just don't have any idea of real hard work." ${ }^{, 52}$ Clearly, Anne J. had no confidence in her crewmates' ability to get the job done, and found them to be not only childish but also irresponsible. Their strained relationship had a negative effect on Anne J., who began to avoid spending time with her crew.

Anne J.'s difficulties with Ginny and Mac took a noticeable toll on her attitude: "I'm going to try to change my crew, because I can't stand this much longer. I definitely don't feel I have an efficient clubmobile that can do anything it's called upon to do. [...] It's hard to do

\footnotetext{
${ }^{49}$ Vaitkus and Griffith, "An Evaluation of Unit Replacement on Unit Cohesion and Individual Morale," 236.

${ }^{50}$ Jane Anne Jack to George Jack, 4 October 1944, original emphasis. Based on the Group E roster available in The Clubmobile, I believe that Ginny is Virginia Weisbrod. Morgan, The Clubmobile, 115.

${ }^{51}$ Jane Anne Jack to George Jack, 14 October 1944, Jane Anne McKee Jack, Box 6, Folder 8, Clubmobile Service Collection.

${ }^{52}$ Jane Anne Jack to George Jack, 16 October 1944.
} 
anything at all when you feel so discouraged about everything." The issues between Anne J. and her crew had a detrimental effect on their efficiency, as well as continually depressing Anne J., who felt that she had to face the difficulties of clubmobile life alone: "I have been thinking of all the really good friends I have in ARC + what hard luck it is I'm not with one of them now."53

However, despite their personal problems, Anne J. and her crewmates had to continue serving the soldiers as best they could: "Ginny has been silent, sulky + sullen for the past few days $[. .$.$] She cooks very well +$ is very cheerful in the clubmobile + I don't think the animosity is apparent, but she would hardly speak to me and also there was a certain element of independence + lack of cooperation. I have just gone along pretending not to notice + trying not to push. ${ }^{, 54}$ This balancing act made daily operations more difficult, as both Anne J. and Ginny had to pretend to be friends even as they engaged in a covert battle of wills.

Angela “Angie" Petesch experienced similar difficulties with her crewmates, and was glad to be promoted to Group H Section Captain because it gave her a break from them. Describing her new job, she confided, 'I'm ashamed to admit one reason why I like it better is because of being separated from 24 hours a day of living and working with the girls who were on my crew. Guess I didn't realize what an unsatisfactory combination of personalities it was, until I was removed from it." As in Anne J.'s situation, Angie never had an actual argument with her crewmates, but instead was the victim of more subtle slights: "One girl was such a dominant character and the other was such a bosom pal and sympathetic friend of hers, that I felt it was two against one the whole time. There were never any quarrels, but I was just a bit overwhelmed. [...] I am out of it and relieved of it." ${ }^{, 55}$ Such examples demonstrate the strain that could result

\footnotetext{
${ }_{54}^{53}$ Jane Anne Jack to George Jack, 16 October 1944.

${ }^{54}$ Jane Anne Jack to George Jack, 19 October 1944, Jane Anne McKee Jack, Box 6, Folder 8, Clubmobile Service Collection.

${ }^{55}$ Petesch, War Through the Hole of a Donut, 175.
} 
from animosity amongst a clubmobile crew, especially because they were forced to hide such feelings and present a friendly, united front to the soldiers.

\section{"The friends you come to treasure"}

However, for the most part, clubmobile crews got along well with one another. ${ }^{56}$ In fact, the personal friendships that formed between crewmembers were an essential part of clubmobile life, allowing the women to enjoy their work and providing a support system during difficult times. Many clubmobilers recorded the importance of their friendships and their dread of being reassigned. Early in their clubmobile service, while operating in the UK, most clubmobilers formed connections to their crewmates. Once on the Continent, friendships between the women became even more essential as the conditions they faced became harsher and more unpredictable, both physically and mentally.

As in the case of war's psychological effects, there is little scholarship on the maintenance or significance of noncombatant morale; however, soldiers have long recognized the importance of unit cohesion, and during the Second World War, military psychologists began studying the significance of bonds between comrades. Scholar Hans Pols notes that military research on morale in the early years of the war concluded that "morale was intimately bound up with the trust soldiers had in their officers, their training, their outfits, their weapons, and their fellow soldiers. It was also related to [...] the nature of the emotional bonds among soldiers and between soldiers and their commanders." ${ }^{57}$ Trust and connections within units allowed soldiers to provide emotional support; scholar Roger Little argues, "Buddies become therapists to one

\footnotetext{
${ }^{56}$ Section title: Norwalk, Dearest Ones, 126.

${ }^{57}$ Pols, "War Neurosis, Adjustment Problems in Veterans, and an Ill Nation," 81.
} 
another. ${ }^{, 58}$ The camaraderie between clubmobilers was likewise significant in providing emotional and physical support to one another, allowing them to continue doing their job and maintain a positive attitude. Because societal norms did not frown upon women displaying emotion, they were perhaps even more likely to turn to one another for emotional support. Scholars have found that while some soldiers need only the general comradeship of the group, many rely on specific friendships with one or two others, which Little termed "buddy relations.. ${ }^{59}$ The same is true for clubmobilers: while there were strong bonds between group members, a woman's individual friendships, usually within a single clubmobile crew, were the most important connection she had. Crewmates had the best understanding of one another's experiences and the specific challenges the women confronted. Additionally, as Martínez Alemán found, female friendships create unique relationships in which women come to rely on one another's support even as they experience individual growth: "The cognitive interdependence that characterized these relationships was one in which autonomy and independence were reconciled. ${ }^{, 60}$ Thus, the bonds between clubmobilers were not only the companionship of "battle buddies," but also uniquely female relationships.

Friendship was especially significant for group captains, who were responsible for the successful operation and well-being of thirty others. Gretchen Schuyler, captain of Group F, commented often about the importance of her personal friendships and their effect on her own morale. For example, in November 1944, Gretchen met up with two of her best friends: "last week I went to Luxembourg City. I met Maxine Preas there and then we met Helen Stockdale! So for the first time since England, we had a reunion dinner. It was wonderful to see them [...]

\footnotetext{
${ }^{58}$ Roger W. Little, "Buddy Relations and Combat Performance," in The New Military: Changing Patterns of Organization, ed. Morris Janowitz (New York: Russell Sage, 1964), 200, quoted in Kindsvatter, American Soldiers, 126.

${ }^{59}$ Little, "Buddy Relations and Combat Performance," quoted in Kindsvatter, American Soldiers, 126.

${ }^{60}$ Martínez Alemán, “College Women's Female Friendships,” 554.
} 
we $[\ldots]$ all enjoyed seeing each other and it did a lot for me. My morale needed lifting." Gretchen, Helen, and Maxine had completed their initial training together and became fast friends. Maxine, like Gretchen, was a group captain, giving her firsthand experience with the unique challenges the job entailed. Gretchen valued the opportunity to see her old friends and talk with someone who knew exactly what her life was like.

Because she was group captain, Gretchen could not confide in her group members as they did in her. Luckily, however, her roommate provided her with an opportunity to share her feelings: "I have a nice roommate [...] A very cheerful,enthusiastic [sic] kid named Bonnie O’Brien. A real good skate, whom I call my 'General Staff'. I talk all my worries over with her. It helps,in [sic] my position, as I can't bleat too loud or the Group would hear about it. So Bonnie and I shoot our faces off together....and the rest are none the wiser!",62 It would have been difficult for Gretchen to hide her feelings from Bonnie; fortunately, Bonnie was both discreet and understanding, providing Gretchen with necessary support at the end of a long day's work.

Chichi Metcalfe's first assignment in Britain built friendships that would last a lifetime. Her crewmates, Leslie "Les" Hart Fenn and Elizabeth "Bibby" Chatfield, would be her companions for much of her Red Cross service. The crew was separated against their wishes after a few months together in Scotland, but were then reunited. Chichi recalled, "The thought was 'sheer heaven,' as Bibby would say, and I could hardly wait for our reunion." ${ }^{63}$ Much to their delight, the women were assigned together as one of the eight crews of Group A.

In early fall 1944, Bibby applied for a job in the Red Cross Public Relations Department in Paris to pursue her talent for writing. Chichi recalled, "We wished her well, but knew that if she moved to Paris we'd miss her quick wit and bubbling personality." When Bibby got the job,

\footnotetext{
${ }^{61}$ Gretchen Schuyler to "family," 23 November 1944.

${ }^{62}$ Gretchen Schuyler to "family," 4 October 1944.

${ }^{63}$ Rexford, Battlestars \& Doughnuts, 15, 21.
} 
Les and Chichi were sad to see her go: "She meant so much to us, we couldn't think of continuing without her. But we felt her new assignment was something she really wanted." Since Bibby was in Paris, Les and Chichi could visit her on leave; unfortunately, in November 1944, Bibby was diagnosed with rheumatic fever and told she would have to be sent home. Les and Chichi were devastated: "The joy and the pleasures of our lovely Thanksgiving and our vacation in Paris evaporated as we realized that the time for our perfect trio had come to an end. [...] Saying goodbye to Bibby was difficult." ${ }^{, 64}$ Bibby continued to write to her crewmates for the remainder of the war, but the crew was never the same.

Jane Phillips also became very attached to her first crewmates, Mary Pitcairn and Anne Ferguson, and all three were devastated when separated in Britain: "Mary andAnne [sic] and I were extremely happy together and wanted very much to remain together as a crew. Every [sic] since they left Mary andAnne [sic] have called about every other night and practically cry about how unhappy they are and they are pulling every string at Headquarters and in the Army to get us together again but I'm not too optimistic about this." Jane knew that the Red Cross and the army usually did not take their workers' feelings into account, even when they affected the women's attitudes toward their work. After Mary P. and Anne F. left, Jane reported, "I have been made Captain of this base and been given two new girls just over from the States to train and be my crew members. I didn't really want to be a Captain at all [...] In a way, I guess I should be flattered for I am the only girl that's been over here as short a time as I have to be made Captain and lots of girls would give their right-arm [sic] to be one. ${ }^{, 65}$ However, Jane's enthusiasm had diminished since her separation from her friends.

\footnotetext{
${ }^{64}$ Rexford, Battlestars \& Doughnuts, 56, 66, 69.

${ }^{65}$ Jane Weir Phillips to Mrs. A.L. Weir, 3 June 1944.
} 
Luckily for Jane, Mary P., and Anne F., they were reunited when all were assigned to Group A. Their friendship was invaluable for Jane, especially in early 1945, when she received the news that her brother was MIA, and likely dead: "Naturally, the shock was awful, not knowing anything else about what had happened. [...] as usual, Mary and Anne were wonderful. They were the only ones I told + they came right in with a big bottle of cognac and made me take several stiff ones. Pretty soon I relaxed for the first time and went to sleep." ${ }^{.66}$ Her friends' support helped Jane cope with her loss and continue to do her job. Without them, Jane would have had a much more difficult time accepting her brother's death and mustering a smile for soldiers just like him every day.

Jane, Mary P., and Anne F. were lucky enough to serve together "for the duration," and Mary P. also benefited from the support of her friends during a personal crisis. Her mother had been sick for a long time, and Mary P. was called home in early June 1945 to say goodbye. Jane's letters reflect the same level of care and concern for Mary P. that she and Anne F. had shown Jane herself. When Mary P. left, Jane "hated like everything to see her go for we had been so close for so long." As the friends parted, Mary P. promised Jane "that she was going to meet me at the docks + take me as far as St. Louis in her dad's car on my way home. ${ }^{, 67}$ Even amidst her personal tragedy, Mary P. was already planning a reunion with her friends.

Mary Small also became the best of friends with her crewmates, Cecelia "Cece" Graham and Helen F. Wolek, affectionately known as "Wally." Their friendship and its importance to the women was best demonstrated by their celebrations of one another's birthdays. For example, Mary S. recounted that she and Cece convinced an army baker "to make cake for the whole mess

\footnotetext{
${ }^{66}$ Jane Weir Phillips to Mr. \& Mrs. Arthur L. Weir, 16 February 1945, Jane Weir Phillips Scott, Box 11, Folder 10, Clubmobile Service Collection.

${ }^{67}$ Jane Weir Phillips to Mr. \& Mrs. Arthur L. Weir, 11 June 1945, Jane Weir Phillips Scott, Box 11, Folder 10,

Clubmobile Service Collection.
} 
hall" for Wally's birthday, and when it was finally finished, "it was well past midnight!"68 Wally loved "the cake which had cost me six hours in the mess hall." 69 A month later, Wally and Cece threw Mary S. a party for her own birthday. Mary S. wrote home, "as long as I live I'll never quite recover-I hope - from that warm glow of happiness and I'll always havea [sic] picture in my mind on any other birthday of the pretty room and the heaped-up pink packages and, above all, of the gay, friendly, familiar faces." ${ }^{, 70}$ The companionship of her friends and the joy of being together were the only gift Mary S. needed on that birthday.

Though she continued to work with Wally and Cece, Mary S. was separated from some of her other clubmobile friends in early 1945 when Group L was split into two smaller sections. Mary S. rarely commented on her own feelings about this separation, but her former coworkers expressed their sadness at being separated from Mary S., Wally, and Cece, who crewed the clubmobile Tampa. Betty South wrote to Mary S., "Several G.I.s have inquired about the Tampa — and it gives my heart a pinch every time. I miss you three so very much—Jean and I often make mention of the lack of fun + laughter since you people [...] went away." ${ }^{, 71}$ Though Jean recognized that missing her friends would only make her job more difficult, she confided that she could not help it: "We miss you all so much. Life hasn't been the same without you nor will it be. [...] Please give my love to the rest of the Tampa crew and tell them I'd give my eye teeth to go back [...] This is not a constructive attitude but it's true — and may we meet soon

\footnotetext{
${ }^{68}$ Mary Churchill Small to "family," 10 March [1945], Folder "MCS Letters from Europe [2]," Papers of Mary Churchill Small.

${ }^{69}$ Mary Churchill Small to "family," 12 March 1945.

${ }^{70}$ Mary Churchill Small to "everyone," 21 April 1945.

${ }^{71}$ Betty South to Mary Churchill Small, 5 April 1945, Folder To MCS from Europe, 1944-45 [1], Papers of Mary Churchill Small. Notes included with the letters reference Betty South. Jean's last name is never specified; based on the Group L roster in The Clubmobile, which seems to list crewmates together, it is likely that she was Jean Gordon, niece and possible mistress of Gen. George Patton, who committed suicide in January 1946, soon after Patton's death. Morgan, The Clubmobile, 99, and “All's Fair in Love and War - 11 Famous Military Leaders Who Kept Mistresses," Military History Now, last modified June 17, 2016, https://militaryhistorynow.com/2016/06/17/womanizing-warriors-11-famous-military-leaders-who-kept-mistresses/.
} 
again."72 Separation from their friends made clubmobiling more difficult for Betty and Jean, who felt their absence keenly each day they went out to serve.

Other letters from Betty demonstrate that Mary S. was especially missed: "Mary dear, we are miserable. The house seems quite, quite empty, and Jean, Maggie and I think it's the most desolate place in the world, excepting Utah beach. There is such a lack of fun and laughter-and I miss you so." ${ }^{, 73}$ The women missed not only Mary S.'s company, but also her wisdom: "Dottie [Love] + Jean + I have good talks about life, love, war, pease [sic] and all the other talkable topics. But we speak so frequently of how much you would lend to such talkings and we would give a great deal to have you with us."74 Mary S. had given her friends someone to discuss the war with, to attempt to understand the complex politics involved in the fighting all around them. The loss of such an intelligent, inquisitive friend greatly affected Betty, who felt unequal to the task of making sense of the chaos without Mary S. by her side.

Other clubmobilers also commented on the difficulties of continuing to do their job after being reassigned away from friends. Margaret Gearhart had worked for months at the Southampton docks with Rosemary "Rosie" Langheldt but was sent to the Continent in February 1945. Soon after her arrival, Margaret told her parents, “No Rosie isn't here—as far as I know she's still back in England-It almost killed her when we left and she had to stay behind."75 The parting was especially difficult because both women knew they were unlikely to work together again. Rosie recalled, "As the memories flooded back of all the terrible and wonderful experiences we've shared, I gave myself a few more minutes to brood over the slim chances of

\footnotetext{
72 Jean to Mary Small, ND, Folder "To MCS from Europe, 1944-45 [1]," Papers of Mary Churchill Small.

${ }^{73}$ Betty South to Mary Small, ND, Folder “To MCS from Europe, 1944-45 [1]," Papers of Mary Churchill Small.

${ }^{74}$ Betty South to Mary Small, 16 April 1945, Folder “To MCS from Europe, 1944-45 [1]," Papers of Mary Churchill Small.

${ }^{75}$ Margaret Gearhart to Mr. and Mrs. W.E. Gearhart (parents), ND, Margaret Gearhart Brodie, Box 1, Folder 6, Clubmobile Service Collection.
} 
our ever being reassigned together again. That's the hardest part of this Red Cross duty. The friends you come to treasure are suddenly snatched away." 76 Indeed, melancholy and lack of enthusiasm following the transfer of a close friend were fairly common among clubmobilers. "We should never have been split up [...] in the first place"

Clubmobile friendships provided emotional support and contributed to clubmobilers' morale; however, the Red Cross did not recognize the importance of these friendships, as their personnel reassignment policies demonstrated. ${ }^{77}$ This lack of recognition could have negative consequences for the organization, for scholars point out that soldiers' ties to their units are only effective motivators and morale boosters when they also have faith in the military at large. ${ }^{78}$ The same was true for at least one clubmobiler who felt that the Red Cross unjustly separated her from her best friend. Group G's Elizabeth "Bettie" Walters formed a strong attachment to one clubmobile crew, and, in particular, to Henrietta Barker. When Bettie was reassigned away from Henrietta's crew in late March 1945, she began openly criticizing the Red Cross, not in the jocular tone employed by The Sinker, but seriously. When the organization removed her from the crew to which she had grown attached, Bettie's ties to these women became detrimental to her own attitude and morale, decreasing her motivation to do her job by causing her to question the wisdom of the Red Cross.

In January 1945, Group G was split in half. One subgroup went to Holland, and Bettie remained in northern France with 14 other women, including Henrietta. Originally a cinemobile operator, Bettie became a clubmobiler at this time because cinemobiles were deemed too difficult to operate during the winter. While Bettie had known Henrietta since her assignment to Group $\mathrm{G}$ in the summer of 1944, her assignment to Henrietta's clubmobile solidified their

\footnotetext{
${ }^{76}$ Norwalk, Dearest Ones, 126.

${ }^{77}$ Section title: Elizabeth "Bettie" Walters to Mr. \& Mrs. Aaron Walters, 14 April 1945.

${ }^{78}$ Kindsvatter, American Soldiers, 133.
} 
friendship. From late December 1944 until Bettie's eventual transfer, she mentioned Henrietta at least once, and often several times, in each letter she sent home. She wrote enthusiastically, "It has been simply wonderful to find a friend like $\mathrm{H}$. She is a wonderful person and we had marvelous times together." 79 These "marvelous times" ranged from everyday experiences in clubmobiling to a leave spent together on the French Riviera.

After about two months working on Henrietta's clubmobile, the Omaha, Bettie received word that she would soon be reassigned: "I got a call from hq. in Paris yesterday saying I should come in with bag + baggage to report for a new assignment. But I wrote a letter last night telling them I wanted to stay permanently in clubmobile + on the crew of the Omaha." ${ }^{, 80}$ In the past, Bettie had always unquestioningly obeyed orders from the Red Cross, and usually expressed enthusiasm about a new job. However, in this case, due to her connections to this particular group of women, she wrote to Paris challenging the order. Unfortunately, she reported a month later, "It seems I am not going to be able to convince Hq. that I prefer clubmobile. I have to stay in cinemobile + I'm going to Belgium Holland [sic]." ${ }^{" 81}$

Bettie was transferred to the other half of Group G in Holland, ostensibly to return to cinemobile operations. Around the same time, her cinemobile partner married and left the Red Cross; as such, rather than rejoining the cinemobile, Bettie was assigned to another clubmobile crew. She railed against the senselessness of her transfer in a letter to her parents: "I will entertain with the clubmobiles until the cinemobiles are gotten out for summer + reorganized. By that time the war will be over + moving me north will have been useless. Believe me, I am putting my bid in for furlough in Oct. when my two years are up. And I doubt if they'll get me

\footnotetext{
${ }^{79}$ Bettie often abbreviated Henrietta's name by simply writing "H." Elizabeth "Bettie" Walters to Mr. \& Mrs. Aaron Walters, 14 April 1945.

${ }^{80}$ Elizabeth "Bettie" Walters to Mr. \& Mrs. Aaron Walters, 23 February 1945, Walters Family Correspondence.

${ }^{81}$ Elizabeth "Bettie" Walters to Mr. \& Mrs. Aaron Walters, 23 March 1945, Walters Family Correspondence.
} 
back again." ${ }^{82}$ Not only was Bettie ready to return home after being transferred away from the Omaha, but the incident had soured her feelings for the Red Cross as a whole. Her animosity toward the organization would subside, but it demonstrates the importance of clubmobile friendships and the potential for transfers to create depression and resentment in clubmobilers.

Following her transfer away from the Omaha, Bettie was noticeably less enthusiastic about her life overseas, and her letters often expressed sadness at her separation from her friends: "It's really a pity I couldn't stay there. I do miss her [Henrietta] so + the others too. They were much more my 'family." ${ }^{, 83}$ Comments like this are especially notable because they stand in sharp contrast to both the tone and content of Bettie's letters up to this point. Before leaving the Omaha, Bettie rarely discussed or reflected on previous experiences; her letters dealt almost entirely with updating her family on her current situation (as much as she could). Her previous letters were also usually enthusiastic about her job, or at least indicated that she felt that she was making a difference and doing something worthwhile. Indeed, soon after being assigned to Group G, before she had formed strong bonds with any of the women, Bettie told her parents, "I'm now in the best job I've ever had + I love it." ${ }^{84}$ She was initially very enthusiastic about the opportunities her new job provided to interact with men close to the front lines.

However, this sentiment was noticeably absent after Bettie left the Omaha. In April 1945, she expressed a lack of motivation and a desire to go home, writing to a friend, "I'm not at all as happy as I was down there with this other bunch. [...] But Hqs. cares nothing about personal feelings. I'll be glad when this thing is over and I can go home -- as soon as they'll let me." 85 This was one of Bettie's first serious mentions of a desire to go home. Especially after VE Day, she

\footnotetext{
${ }^{82}$ Elizabeth "Bettie" Walters to Mr. \& Mrs. Aaron Walters, 11 March 1945, Walters Family Correspondence.

${ }^{83}$ Elizabeth "Bettie" Walters to Mr. \& Mrs. Aaron Walters, 6 April 1945, Walters Family Correspondence.

${ }^{84}$ Elizabeth "Bettie" Walters to Mr. \& Mrs. Aaron Walters, 14 June 1944, Walters Family Correspondence.

${ }^{85}$ Elizabeth "Bettie" Walters to Agnes Bard, 16 April 1945, Walters Family Correspondence.
} 
seemed to have become burnt out, a fact that she attributed not only to the war's end but also to her separation from her friends: "there's no longer any excitement connected with our work [...] It sure makes a difference who you work with now more than ever. [...] Guess we have all just let down since VE day. If I was with my own gang I think my enthusiasm would be just as good as it was before." 86 Clearly, Bettie's lack of enthusiasm was not merely due to the war's end and her time away from home, but the fact that she was separated from the Omaha's crew.

Unlike many clubmobilers who faced a transfer, especially in the UK, Bettie was not reassigned to a completely new crew; she knew the women she was working with, since they had been the other half of the original Group G. However, at the time of her transfer, her personal friendship with Henrietta and the Omaha's crew was more valuable to her than the camaraderie of the group: "I don't do anything without thinking how much I wish Henrietta could be with us. This whole thing has been so unnecessary from the beginning. We should never have been split up as a group in the first place. [...] As I told you before it is fine being with the other girls again but nothing will ever take the place of that little group down in the seventh army." 87

Bettie did all she could to remain connected with her friends. Though she had spent previous leaves sightseeing in places she might never visit again, like Scotland and the French Riviera, Bettie spent her final two leaves visiting Henrietta and the Omaha. Though Bettie was on leave, her friends were still working, so Bettie joined them, reporting that she "drove the Omaha in the convoy yesterday when the girls moved to a new position.” In fact, visiting the Omaha felt like a step back in time: "It's wonderful to be here with all the girls again. And it's so good to see Henrietta. [...] It was just like old times when the four of us did things together." This included everyday tasks like finding a new place to live in a new city. The house that the

\footnotetext{
${ }^{86}$ Elizabeth "Bettie" Walters to Mr. \& Mrs. Aaron Walters, ND [late May/early June 1945], Walters Family Correspondence.

${ }^{87}$ Elizabeth "Bettie" Walters to Mr. \& Mrs. Aaron Walters, 14 April 1945.
} 
army assigned them at the Omaha's new position had "a darling apartment with one bedroom + two good beds. So we [Henrietta and I] immediately moved up here." This allowed Bettie to spend as much time as possible with her best friend. She commented, "If the girls move much more while I'm here, I'll never get back to $9^{\text {th }}$ Army. Wouldn't mind that a bit. I feel so at home with this group + as though I belong. ${ }^{\prime 88}$ Upon returning to her own assignment, Bettie again expressed her loneliness and desire to remain with the Omaha.

Ironically, Bettie enjoyed this leave far more than she probably would have enjoyed a sightseeing trip alone, and it provided a welcome respite from her normal job by allowing her to spend time with the women she loved. Allowing leave to its workers was one of the few ways that the Red Cross attempted to keep up their morale, yet Bettie chose to take what would today be called a "working vacation." Red Cross supervisors may not have approved, but it seems that this vacation was as uplifting for Bettie as any of her previous trips because it allowed her to spend time with her clubmobile family, especially Henrietta.

By June 1945, Bettie's dissatisfaction had grown so great that after visiting Henrietta and the Omaha for a second time, she wrote, "I have just about decided to stay [with Henrietta's group in Salzburg] anyway + take the consequences. They can only send me home anyway." 89 Bettie's attachment to the Omaha, and Henrietta, was so strong, and her disillusionment at being separated from them so great, that she contemplated breaking Red Cross rules to remain with them. Though she ultimately returned to her own assignment, Bettie's consideration of such drastic action demonstrates the strength of her friendship with Henrietta and the Omaha's crew.

Connections among clubmobile women helped them cope with the dangers and challenges that they faced in the war zone. However, the Red Cross underestimated the strength

\footnotetext{
${ }^{88}$ Elizabeth "Bettie" Walters to Mr. \& Mrs. Aaron Walters, 22 April 1945, Walters Family Correspondence.

${ }^{89}$ Elizabeth "Bettie" Walters to Mr. \& Mrs. Aaron Walters, ND [June 1945], Walters Family Correspondence.
} 
of the connections between individual women and their importance in maintaining clubmobilers' morale. Like soldiers who became attached to their units and strongly resisted reassignment, Bettie Walters' personal ties to her coworkers on the Omaha led her to become increasingly depressed and dissatisfied when she was separated from them. Her desire to remain with Henrietta after a short visit is in some ways reminiscent of American soldiers who went "AWOL to the front" to avoid being reassigned when released from the hospital. This action on the soldiers' part, Kindsvatter argues, came partially from a sense of responsibility to their unit and partially from their wish to avoid "be[ing] sent to fight with strangers in some new outfit.",90 Interestingly, Bettie's reassignment was to rejoin the other half of Group G; she was not thrown into an entirely new unit with strangers, yet she was still extremely unhappy at the change. The strength of her dissatisfaction and its effect on her attitude toward both her job and the Red Cross at large indicates the importance of personal friendships among clubmobile women.

The nature of clubmobile work placed a small group of women into a sea of men, so it is understandable that the women began to bond with one another. These relationships quickly became essential. When conflicts arose between crewmembers, the day-to-day tasks of clubmobile life became a chore, and the women welcomed any chance to avoid their daily routines. But when crewmembers shared the bonds of friendship, the women remained upbeat and dedicated. Unfortunately, the Red Cross ignored the importance of these ties to one's unit. When separated from the group to whom she had formed strong bonds, their connections could make a clubmobiler depressed and resentful of the Red Cross for separating her from her family. Though they occasionally attempted to keep friends together, Red Cross officials were more concerned with soldiers' morale than their personnel's preferences, and clubmobile groups and even crews were split up when headquarters deemed necessary.

\footnotetext{
${ }^{90}$ Kindsvatter, American Soldiers, 132.
} 
Though all Red Cross women felt a certain connection to one another, the challenges of clubmobile life were unique, and led to uniquely strong bonds between clubmobilers. Witnessing death, diving into foxholes, and sharing the burden of soldiers' confidences, clubmobile women saw war much more intimately than other Red Cross workers. These experiences created a bond between all clubmobilers that no other woman, or even Red Cross worker, could understand. More importantly, everyday experiences and shared dangers created friendships that could not be replaced even by the camaraderie of clubmobilers. To the women, the Red Cross was a huge extended family; clubmobilers were one family unit within that extended family, all sisters; but a clubmobile crew was closer than sisters - they were triplets, tied together by the unique experiences they shared, experiences that had brought them into this family.

Contemporaries' failure to recognize the depth of clubmobilers' connections was a symptom of societal attitudes toward gender. Scholar Lillian Rubin argues, "just as women have been invisible in public life throughout the ages, so their private relations with each other have been unseen as well." ${ }^{91}$ Clubmobilers relied on one another for support and advice in a maledominated world. In addition to gendered challenges, they also faced the difficulties of surviving in an active war zone with little to no official support. Their experiences offer not only an example of the importance of female friendship, but the benefits of camaraderie for noncombatants working alongside the military during wartime. Clubmobilers' bonds were the result of the unique combination of their position so close to the front lines, their noncombatant status, and their gender, which defined the expectations placed upon them. When they returned home, gender roles ensured that public ignorance of clubmobilers' experiences continued for decades after the war, even as the women's connections and friendships remained strong.

\footnotetext{
${ }^{91}$ Lillian B. Rubin, Just Friends (New York: Harper \& Row, 1985), 59, quoted in Fischer, “Girl Groups,” 219.
} 


\section{Chapter 5: "[W]e've grown beyond their understanding": Homecoming and beyond}

Following VE Day, clubmobilers continued to serve men now dreading reassignment to the Pacific. ${ }^{1}$ As the German occupation began, clubmobile operations were scaled down to serve occupation troops into 1946. Veteran clubmobilers looked upon the green occupation troops and the newly arrived clubmobile replacements with the understanding that they were witnessing the end of an era; these personnel fresh from the US could not understand what their lives had been like or what they had experienced.

However, the end of the war did not represent the end of clubmobilers' subordination to men, nor of the bonds they shared. The feeling of anticlimax that the women experienced on VE Day was enhanced by the fact that clubmobilers were expected to maintain their enthusiasm as they watched friends, both Red Cross and GI, leave for home. When the women finally arrived home, they found that no one knew or cared what they had done overseas. Society, and indeed the historical community, looked only to male soldiers for war narratives. As such, clubmobilers were denied any recognition of their experiences and struggles, silencing their voices in the story of the war. More immediately, they were offered no benefits or services to ease their transition home; as during the war, clubmobilers had only one another's support as they readjusted to civilian life.

\section{" Should I really go"”}

Though most clubmobilers were eager to go home once the war was over, only those who had been in the Red Cross for two years or could provide a compelling reason (i.e. family illness) were allowed to return home. ${ }^{2}$ Indeed, the US Navy newspaper noted that a clubmobiler's

\footnotetext{
${ }^{1}$ Chapter title: Morgan, The Clubmobile, 120.

${ }^{2}$ Section title: Fay, "Through a Donut Hole," Chapter 25.
} 
"[a]verage length of time overseas is well above that for the average soldier." ${ }^{, 3}$ Many

clubmobilers, having worked in the UK before being sent to the Continent, reached two years of service and returned home in the summer and fall of 1945, though some stayed into 1946.

After VE Day, clubmobile women found it increasingly difficult to keep up their own morale. Mary Lou(ise) Pearce's comment, "Our work was not as exciting [...] Everyone wanted to go home," is representative of this period. ${ }^{4}$ The enthusiasm that had sustained them for months was lost with the end of hostilities, and clubmobilers began to realize just how tired they were. Gretchen Schuyler explained, "The girls who have been in the racket for two years are fed to the gills. All of a sudden a complete exhaustion has overtaken us all. [...] We have several personnel problems concerning mental and physical health." the summer of 1944 had been serving the men under fire for nine to ten months, practically nonstop, and with the sudden peace, Mary Small reported, "everyone is unhappy, restless, full of gripes, obsessed with the feeling that nothing really matters anymore." ${ }^{\prime 6}$ As Mary attempted to explain to her family, they had done their job, and been proud to do it,

But now the job is anything but vital and, if it is to continue at all, needs the injection of new blood. We're such old war horses that we have been away from theStates [sic] longer than most of the outfits we serve. [...] many of us have reached the point where we are losing the capacity for exchanging wisecracks, shouting and screaming with laughter at the old, old gags, and generally making darn fools of ourselves so that 500 men at once can get a kick out of having American girls around. For the sake of my own morale (that much over-worked word) I have got to get a job which will demand more in the way of mental effort and less of an inevitably superficial personality set. ${ }^{7}$

Many veteran clubmobilers realized that they were no longer suited for the job, for their experiences only isolated them from both incoming clubmobilers and the occupation troops.

\footnotetext{
3 “ARC Chicks Love GIs But Have One Gripe: ‘Don't Call us Fraulein,”” Scuttlebutt, July 27, 1945, Jane Anne McKee Jack, Box 10, Folder 6, Clubmobile Service Collection.

${ }^{4}$ Hart, "This is the Way it Was," 42.

${ }^{5}$ Gretchen Schuyler to Mrs. C.J. McCarthy, 7 April 1945, Box 3, Binder 5, Papers of Gretchen Schuyler.

${ }^{6}$ Mary Churchill Small to "everyone," 5 July 1945, Folder "MCS Letters from Europe [3]," Papers of Mary Churchill Small.

${ }^{7}$ Mary Churchill Small to "everyone," 10 June 1945.
} 
In addition to the general ennui created by the end of European hostilities, clubmobile life experienced major changes in the summer of 1945 as clubmobilers watched soldier friends return home while their work continued. In early June, Gretchen Schuyler explained to her family, "Lots of the girls who are interested in men of the S.S. [Special Services] Company have been in here to see them off for HOME. They pulled out of here yesterday and we feel a great void around us. They were a wonderful gang. We lived with them almost the entire past 10 months." The departure of familiar troops meant that clubmobile groups were broken up as the women were reassigned to new units on newly formed bases, mainly in Germany. Aside from the loss of companionship, clubmobilers like Mary Small "rather dread all the new contacts to be made."9 Mary later commented, "I can't get used to garrison life [...] And certainly the ex-combat men can't; they despise it. ${ }^{10}$ Like ex-combat men, Zone V clubmobilers were used to living rough and making decisions as needed, without waiting for approval from headquarters. The stricter, more regulated life of the occupation meant the loss of their independence.

Gradually, clubmobilers received the bittersweet order to return home. Group A's Mary "Chichi" Metcalfe recalled, "While I was waiting to depart, I wrote notes to the girls on the clubmobiles, telling them I already missed them and how very much their friendships had meant and would always mean to me. I loved and admired them in ways I couldn't express. The warmth among us had gotten us through some very grim times."11 The joy of returning home was mixed with the sorrow of leaving friends, often on short notice. Group K Captain Elma Ernst, overseas since December 1942, was one of the earliest to leave:

\footnotetext{
${ }^{8}$ Gretchen Schuyler to "Katie and all the rest," 10 June 1945, Box 1, Folder 1945, Papers of Gretchen Schuyler. ${ }^{9}$ Mary Churchill Small to Aunt Barbara, 12 July [June?] 1945, Folder "MCS Letters from Europe [3]," Papers of Mary Churchill Small.

${ }^{10}$ Mary Churchill Small to "family," 3 July 1945, Folder "MCS Letters from Europe [3]," Papers of Mary Churchill Small.

${ }^{11}$ Rexford, Battlestars \& Doughnuts, 133.
} 
that was one of the saddest moments for the five of us who [...] received a call from Headquarters on a Thursday night to report to Paris by Saturday morning to go home. Although we had been expecting a call for two months, when it did come, all of us said, "Should I really go." We thought of all our friends still there, of the close associations for so long a time, of how we would miss all that. [...] as we waved goodbye to [...] our friends [ ...and] made our way up to the front of the ship, the tears were falling freely. ${ }^{12}$

Elma and the others had only a day to prepare for their departure, and upon arriving in New York, they dispersed quickly, rushing off to catch trains with hardly the time to bid one another farewell. It was a rather abrupt end to the long months of companionship.

\section{"I didn't have anything in common with anyone back here",}

Once they returned home, clubmobilers found it difficult to readjust to civilian life. ${ }^{13}$ One clubmobiler attempted to put into words how the war had affected those who experienced it: "we'll be gentler and a lot more tolerant and very fed [up]—some with monotony, some with suspense - and very materialistic for awhile. We're tired to the core of ruin and devastation, of dealing it out and having to look at it. [...] If civilians think we've changed, it's merely that we've grown beyond their understanding. They haven't been here, they haven't 'had it'."14 The Red Cross newspaper quoted the prevalent sentiment, “'After the first thrill of seeing the family and a few good friends, I felt lost. I didn't have anything in common with anyone back here.” 15

Soldiers experienced much the same disconnect from civilians that clubmobilers described. Scholar Paul Fussell argues that returning soldiers felt that "optimistic publicity and euphemism had rendered their experience so falsely that it would never be readily communicable." ${ }^{" 16}$ The violence and destruction they had witnessed were experiences that simply could not be explained to civilians, whose understanding was often constricted to the recognition

\footnotetext{
${ }^{12}$ Fay, "Through a Donut Hole," Chapter 25.

${ }^{13}$ Section title: “'You Never Had It So Good,” Over Here, Feb. 1, 1946, Virginia Storts Hall, Box 2, Folder 15, Clubmobile Service Collection.

${ }^{14}$ Morgan, The Clubmobile, 120.

15 "'You Never Had It So Good."”

${ }^{16}$ Fussell, Wartime, 268.
} 
of a change in returning soldiers. Historian Thomas Childers observes that the phrase, "“He was never the same after the war,' was quite a common observation at the time," for loved ones could not fail to recognize the challenges their men faced upon returning home. However, Childers highlights that "as early as 1946 [civilians] were growing weary of angry veterans and their problems." ${ }^{\prime 17}$ If people quickly tired of soldiers' struggles to readjust to civilian life, they completely ignored clubmobilers' experiences. Indeed, Gretchen Schuyler recalled, 'Few persons were able to visualize just what we did and how we did it." ${ }^{18}$ Clubmobilers' position was so unusual, and in many ways contrary to contemporary ideas of "women's work," that they struggled to explain their wartime service. Additionally, clubmobilers had returned to a society in which “"Experts' generally instructed American women to defer to the men returning from war," as historian Sonya Michel highlights. ${ }^{19}$ This perpetuated the expectation that women's needs be subordinated to men's, regardless of the women's own individual experiences.

The Red Cross did little to recognize clubmobilers' service, even forbidding them from displaying military awards. Soon after VE Day, some Group A clubmobilers received five battle stars from the military. Chichi Metcalfe explained, "Although we had not engaged in any of the battles, the army had designated specific geographical areas as battle zones and had authorized battle stars to be awarded to those serving a minimum of thirty days with any units which had participated in engagements within those regions." Unfortunately, the Red Cross forbade the women from wearing the stars, or even the ETO army service ribbon. ${ }^{20}$ This decision, likely due

\footnotetext{
${ }^{17}$ Thomas Childers, Soldier from the War Returning: The Greatest Generation's Troubled Homecoming from World War II (Boston: Houghton Mifflin Harcourt, 2009), 2, 7.

${ }^{18}$ Schuyler, "Operational Outline History of the American Red Cross Clubmobile Group 'F,"” foreword.

${ }^{19}$ Sonya Michel, "Danger on the Home Front: Motherhood, Sexuality, and Disabled Veterans in American Postwar Films," Journal of the History of Sexuality 3, no. 1 (Jul. 1992): 111, http://www.jstor.com/stable/3704374.

${ }^{20}$ Rexford, Battlestars \& Doughnuts, 115-6.
} 
to the Red Cross' desire to maintain the appearance of the women's noncombatant status, deprived clubmobilers of one of the only recognizable acknowledgements of their experiences.

While it was rare for civilian noncombatants like clubmobilers to receive military awards, this occurred in several instances. Eva Christensen, for example, received both "the Medal of Freedom and the Certificate of Outstanding Service to the United States Army." 21 The criteria of these awards are broadly worded to include "a meritorious act or service which has aided the United States in the prosecution of a war against an enemy or enemies," making it likely that the awards recognized Eva's service to the soldiers. ${ }^{22}$ Additionally, a few clubmobilers were awarded the Bronze Star. ${ }^{23}$ Gretchen Schuyler's Bronze Star citation was representative in its declaration that, "The manner in which she performed her duties materially contributed to the maintenance of high morale among the soldiers." 24 Thus, even after the war, clubmobilers were defined and recognized solely in relation to their effect on the soldiers.

After the war, federal initiatives, most notably the GI Bill, attempted to address some of the issues, such as job and housing shortages, that arose as soldiers returned home. These efforts were almost entirely focused on male reintegration, in part because women made up only $2 \%$ of veterans of the armed forces, due to wartime caps on enlistment. ${ }^{25}$ Though female military veterans were technically eligible for GI Bill benefits, scholar Melissa Murray highlights that

\footnotetext{
${ }^{21}$ Johnson, I Too Shall Wear Purple, 232. Predecessor of the modern Presidential Medal of Freedom, the Medal of Freedom was established by President Truman in July 1945 to recognize non-military individuals ineligible for other federal awards. It could be awarded by the president; secretaries of state, war, and the navy; and their designees. Due to the number of officials with the power to award it, there is no official record of all recipients; scholars believe as many as 22,000 Medals of Freedom were awarded between 1945 and 1961. Kyle C. Kopko et. al., "The Politics of the Presidential Medal of Freedom: A Fifty Year Analysis, 1963-2013," New England Journal of Political Science 8, no. 2 (2015): 158-9, https://ecommons.udayton.edu/cgi/viewcontent.cgi?article=1081\&context=pol_fac_pub.

${ }^{22}$ Kopko, "The Politics of the Presidential Medal of Freedom," 158.

${ }^{23}$ Elma Ernst Fay, Gretchen Schuyler, and Elizabeth Schuller, the first Red Cross woman to receive an army award other than the Purple Heart during WWII. Korson, At His Side, 283; "Citation for Bronze Star Medal," Elma Ernst Fay, Box 2, Folder 5, Clubmobile Service Collection; and "Citation: Gretchen Schuyler, Bronze Star Medal," Box 3, Binder 3, Papers of Gretchen Schuyler.

${ }_{24}$ "Citation: Gretchen Schuyler, Bronze Star Medal."

${ }^{25}$ Murray, "Made with Men in Mind," 89.
} 
women rarely took advantage of them. Indeed, she finds that, "Whereas male veterans were advised of their eligibility for education and training benefits in the course of discharge, women veterans often were not. ${ }^{, 26}$ Murray argues that the GI Bill ultimately reinforced traditional gender roles by privileging soldier employment above all, helping male veterans return to their traditional role as breadwinners.

As Red Cross workers, clubmobilers were ineligible for federal veterans' benefits; indeed, because the word "veteran" usually signifies past service in the armed forces, clubmobilers could not even claim this title. Unlike female service members, clubmobile women had to deal with the housing shortage that arose in postwar society without even the possibility of benefits. Indeed, many clubmobilers, having been overseas for two or more years, lived with their parents or other relatives in the months after they returned home. In addition to the lack of benefits, clubmobilers returned to a society with limited opportunities for women. In postwar education and the job market, Murray finds that institutions privileged veterans over non-veterans, essentially limiting opportunities along gender lines. ${ }^{27}$ Sonya Michel argues, "Women were not only to surrender their jobs, but also to subordinate their own dreams, ambitions, and desires to those of the [male] veterans. ${ }^{, 28}$ Such discrimination further limited female employment as women were pushed out of wartime jobs to make way for returning soldiers. Some clubmobilers were fortunate enough to return to pre-war jobs; however, they found most traditionally female positions quite dull in comparison to clubmobile life. In this, their experiences paralleled those of soldiers. Scholar Hans Pols asserts that, after being "given positions of power and responsibility [...] few soldiers would be happy to merely take up the jobs they had left behind."29

\footnotetext{
${ }^{26}$ Murray, "Made with Men in Mind," 91.

${ }^{27}$ Murray, "Made with Men in Mind," 89.

${ }^{28}$ Michel, "Danger on the Home Front," 112.

${ }^{29}$ Pols, "War Neurosis, Adjustment Problems in Veterans, and an Ill Nation," 84.
} 
In addition to such problems, readjusting to the rules of etiquette and proper female behavior proved especially vexing for clubmobilers. Elma Ernst found, "It was hard not to speak to every soldier $[\ldots]$ on the street," but well-bred young women did not speak to strange men. ${ }^{30}$ The women also dreaded losing the comfort and practicality of their clubmobile uniforms. Gretchen Schuyler confided to her family in January 1945, "I have been wearing paratroop boots since last April. Before that I wore regular G.I.s, and now and then when the mud is deep I wear combat boots. My feet love it! But Egad, what will they be like when I put on street shoes and try to walk the pavements of NY? ${ }^{31}$

Civilian life was far more restrictive than the independent, self-reliant lives clubmobilers had lived on the Continent, prompting one clubmobiler to confide to the Red Cross newspaper in February 1946, “"The restlessness and dissatisfaction, the desire to be back on that old job, and the envy we feel for those of you still over there are overwhelming emotions. The emptiness that makes up life in the States these days for those of us who have been overseas with troops is something we've all got to reckon with." ${ }^{32}$ It is perhaps unsurprising that some clubmobilers married former soldiers, who shared similar experiences both overseas and upon returning home, and that the women worked hard to maintain their connections to one another.

\section{Not just "for the duration"}

Clubmobilers' bonds lasted long after the war's end. One clubmobiler wrote to the Sinker News Letter (published for those serving in occupied Germany), "Of course it goes without saying that my heart is back there with Clubmobile Group L [...] Ah, to be a doughnut queen again!" ${ }^{33}$ Another confided to the Red Cross newspaper in February 1946, “"All of our old group

\footnotetext{
${ }^{30}$ Fay, "Through a Donut Hole," Chapter 25.

${ }^{31}$ Gretchen Schuyler to "Katie and all the rest," 14 January 1945.

32 "“You Never Had It So Good."”

33 “The Sinker Stinker," Sinker News Letter, Dec. 1, 1945, Virginia Storts Hall, Box 2, Folder 12, Clubmobile Service Collection.
} 
[...] write to each other constantly.", ${ }^{34}$ In 1984, Elma Ernst commented, "I think I formed some of my best friendships during those years. I still keep in touch with many of them." ${ }^{35}$ After returning to the US, Elma continued working for the Red Cross. Her desk job was far from exciting, until "one day a girl came in whom I had known overseas. We greeted each other like long lost sisters - all business completely forgotten." Soon after, "five of the girls from our group who had just come home, came out to have lunch with me. I discreetly met them outside—-better no $[t]$ create a disturbance inside - I knew those gals. After lunch $[\ldots]$ they all came into the office and to my desk [...] What a ribbing I took about my 'chairborne' activities." ${ }^{36}$ The visit brightened Elma's day, reminding her of the adventures and camaraderie she had experienced overseas. The good-natured "ribbing" she received was standard procedure for a clubmobiler, but Elma knew that she and her friends would be considered too rowdy for a stateside office, where no one could understand the unique bond they shared.

Beyond individual friends staying in touch, clubmobilers as a whole worked to ensure that the women of this unique service stayed connected for decades. Clubmobile Group A published an annual "Group A Newsletter" from 1953 to 1980, allowing group members to maintain the connections they had formed during the war. However, the most lasting testament to the sense of camaraderie among clubmobilers was their formation of the Clubmobile Association in 1946. The Association's board served two-year terms consistently until 1976, and it continued its activities into the 1980s, allowing former coworkers to work alongside one another again. For example, Elizabeth "Bettie" Walters (MacInnes) served as Association Vice President at the same time that Henrietta Barker (Kyle) was secretary-treasurer, allowing these best friends to

\footnotetext{
34 “"You Never Had It So Good."”

${ }^{35}$ Andree Hickok, "Woman tells of service overseas during WWII," Sunday Post (Bridgeport, CT), Aug. 12, 1984, Elma Ernst Fay, Box 2, Folder 5, Clubmobile Service Collection.

${ }^{36}$ Fay, "Through a Donut Hole," Chapter 25.
} 
work together long after the war's end. ${ }^{37}$ The Clubmobile Association also published a newsletter, the Sinker $J r$., which included memories from clubmobile service as well as information about significant events in its members' lives, from marriages to deaths. In 1981, the list of deceased members numbered $65 .{ }^{38}$ It is likely due to the aging of its membership and their increased mortality rate that the Association's activities became less regular in the 1980s.

However, despite the decline in Clubmobile Association membership, clubmobilers stayed connected through the American Red Cross Overseas Association (ARCOA). Founded in 1949, ARCOA membership is open to any individual who has served overseas as a member of the American Red Cross. ${ }^{39}$ Joining ARCOA allowed clubmobilers to maintain their connections, not only to the Red Cross in general, but also to one another. Indeed, two of the women suggested that clubmobilers could "have our own annual meeting yearly on the Friday evening before the A[RC]OA convention on Saturday." felt that their experiences, and thus their connections, were unique and significant.

The mix of horrors and triumphs that clubmobilers faced on a daily basis, and their unique position as the only women allowed so close to the front, forged bonds between them that could not be compared to anything else. Chichi Metcalfe recalled, "I would always treasure the friendships of the women I had met. The clubmobile girls had been an outstanding group and, in spite of many hardships, inconveniences, and discouragements, we had had a lot of fun. Living together under wartime conditions gave us a cohesiveness and camaraderie that was unparalleled. ${ }^{, 41}$ This camaraderie would last long after the war had ended, when clubmobiles

\footnotetext{
37 "Statistics: Executive Board," Sinker Jr., Elma Ernst Fay, Box 2, Folder 5, Clubmobile Service Collection.

38 "Deceased," Sinker Jr., 33-4, Elma Ernst Fay, Box 2, Folder 5, Clubmobile Service Collection.

39 "Join Us," American Red Cross Overseas Association, accessed August 12, 2019, https://www.arcoa.org/join-us.

${ }^{40}$ Bettie MacInnes, "Minutes 1981 Meeting," Sinker Jr., 19, Elma Ernst Fay, Box 2, Folder 5, Clubmobile Service Collection.

${ }^{41}$ Rexford, Battlestars \& Doughnuts, 135.
} 
were all but forgotten. In 1994, a reporter commented, "Ask a clubmobiler what she remembers most besides the thousands of GIs she served while on duty, and she inevitably tells you about the camaraderie she felt with her sister ARC workers." ${ }^{42}$

The soldiers were why she was there, but the women she worked with were what made a clubmobiler's life not only bearable, but enjoyable. Chichi Metcalfe noted, "Like the strong friendships that servicemen formed once they enlisted or had been drafted, the friendships that Red Cross girls shared were precious. We helped each other through some hard times, but mostly we had fun together." ${ }^{43}$ The women helped one another find humor and joy in their situation. They teased one another and the soldiers they served incessantly; they commiserated over temperamental donut machines and ascribed personalities to their clubmobiles. They relied on one another to keep their morale high so they could raise soldiers' spirits.

\section{Clubmobilers'legacy: Vietnam}

While clubmobilers have been all but forgotten, Vietnam-era "donut dollies" are more well-known. However, the women of the Supplemental Recreational Activities Overseas (SRAO), commonly called "donut dollies," had a very different experience from their World War II predecessors. Though their mission was the same - raising army morale, especially in remote, often dangerous areas, - - the women who served in Vietnam used different means to do so. SRAO donut dollies, ironically, served neither donuts nor coffee in the tropical heat of Vietnam; their main task was to devise and lead recreational activities.

Most significantly, the life of an SRAO donut dolly was a much more solitary existence than a clubmobiler's. Because neither the Red Cross nor the military had recognized the importance of the women's morale, they did nothing to improve the experience of recreation

\footnotetext{
${ }^{42}$ Louise W. Demakis, “The Donut Girls of WWII: Forgotten veterans of Normandy's beaches," Minuteman, June 2, 1994, Elma Ernst Fay, Box 2, Folder 5, Clubmobile Service Collection.

${ }^{43}$ Rexford, Battlestars \& Doughnuts, 4.
} 
workers in the 1950s and 1960s. SRAO workers had nothing like the large groups of thirty women that were the basis of clubmobile life on the Continent. In fact, they didn't even have the bond that formed between the women of a single clubmobile crew. Though Red Cross regulations dictated that SRAO women always travel in pairs, they usually separated once they reached a unit in order to serve as many men as possible. Additionally, they were reassigned every few months, reducing their opportunity to form connections with one another. ${ }^{44}$ Joann Puffer Kotcher, who served in both Korea and Vietnam as a member of the SRAO, remembered, "I didn't have the collegiality with the girls to fall back on, because we did not develop friendships. [...] When we worked, we worked mostly alone. [...] When we had a day off, we had it alone. We didn't spend social time together, because we didn't have free time. [...] Every moment of our days we spent with the men. They were the reason we were there, and we gave them all of our attention." ${ }^{, 45}$ While this last sentiment applied to clubmobilers as well, the nature of their war allowed, and indeed required, clubmobile women to form connections with one another. Unfortunately, the Red Cross and the military failed to recognize the importance of camaraderie to the women's morale, relegating SRAO donut dollies to an isolated existence.

The relationships that World War II's clubmobile women formed were essential to their own happiness and well-being, and would continue long after the war had ended. Even as they married, pursued careers, and built new families, clubmobilers strove to maintain their connections to one another. Thirty-five years after the war had ended, clubmobilers were still meeting annually, though their numbers were beginning to dwindle. And even as most of the

\footnotetext{
${ }^{44}$ One former SRAO donut dolly believed the frequent moves were designed to prevent the women from forming relationships with soldiers that could damage their, and the Red Cross', reputation. Joann Puffer Kotcher, Donut Dolly: An American Red Cross Girl's War in Vietnam (Denton, TX: University of North Texas Press, 2011), 5. ${ }^{45}$ Kotcher, Donut Dolly, 274-5.
} 
world forgot what a clubmobile was, the men whose lives they touched did not. ${ }^{46}$ Clubmobile women have been overlooked in the decades since the end of World War II; even the donut dollies of Vietnam knew little about their predecessors, the pioneers of the clubmobile. ${ }^{47}$ It is long past time that we stop disregarding these women, as their superiors did, and recognize clubmobilers for what they were: soldiers in the war for morale.

\footnotetext{
${ }^{46}$ In 1989, for example, former private Roland Sluder discovered a letter to his mother dated January 5, 1945, informing her that Eleanor "Dugal" Campbell had just served her son "somewhere in France." Sluder found Dugal and invited her to attend the spring meeting of the $94^{\text {th }}$ Infantry Division Association, where she received a citation thanking her for her work during the war. Though they had met only once as a 19 -year-old private and a 26 -year-old clubmobiler, the two greeted one another like old friends. Arnold Abrams, "Letter Reunites 94th GI, Red Cross Worker," Attack, Official Publication of the 94th Infantry Division Association, Winter 1990, Eleanor Campbell Schroeder, Box 11, Folder 6, Clubmobile Service Collection.

${ }^{47}$ This is apparent from Kotcher's description of World War II-era clubmobiles as "converted pick-up trucks and single-deck buses." Though Kotcher mentions clubmobilers' proximity to the front, most of her facts (such as clubmobiles' reliance on male drivers) seem to refer to service in the UK. Kotcher, Donut Dolly, 2.
} 


\section{Conclusion}

A clubmobiler's life was unique: "part civilian, thoroughly GI, military when its [sic] convenient and official, and strictly combat." Whether digging foxholes or serving donuts, a clubmobiler was closer to a soldier than perhaps anyone besides his own buddies. When people asked clubmobilers "how conditions are up front," the women could speak from experience: "We tell them, for we ought to know-we've been there." In fact, clubmobilers understood far more than most; they "had a bird's eye-view that any general would give his front seat in hell for."1 Unfortunately, the women's wisdom and experience was often overlooked by a system that privileged male experiences above all, and dictated that a woman's role was to support men, even to her own detriment. As a result, only the women themselves truly understood one another's experiences and recognized the importance of maintaining their own morale.

The existence of clubmobilers, as well as the expanded morale services offered by the military during World War II, challenges the "band of brothers" thesis that suggests male unit cohesion is the single most important factor in military morale. However, for the women themselves, their clubmobile family was the most significant morale service available to them. The gender norms that legitimated their role led officials to ignore the women's well-being, both during their service and in the postwar years. As such, the women were left to deal with the daily challenges of their role on their own, with almost no help from officials.

Though their independence appears paradoxical in light of contemporary notions of the male soldier as the protector of the female wife or sister, it is in fact symptomatic of the system's privileging of men's needs. By leaving the women to fend for themselves, officials demonstrated that their concern was not, and never had been, the women's well-being, but rather the men's

\footnotetext{
${ }^{1}$ Morgan, The Clubmobile, 119-20.
} 
morale. The women received the minimum amount of training and a few concessions regarding leave time, which were just enough to ensure that they could continue to do their job. The amount of independence they enjoyed demonstrates that officials had no idea of the conditions they faced; even military commanders were largely ignorant of the women's experiences. While soldiers claimed to value the women's sacrifices, they had no idea of their true extent. Soldiers failed to recognize the emotional strain they placed upon the women by sharing their war experiences, which only compounded what the women had witnessed themselves. However, in the ideology of the day, a woman's role was to support men; how she did so and what she sacrificed were unimportant, often even to the woman herself.

Clubmobilers were not officially considered soldiers, and ultimately, they had no one but one another to rely upon as they faced the challenges of war and the demands of the Red Cross and the soldiers. The answer to the question "“Who takes care of the Red Cross's morale?" was clubmobilers themselves. ${ }^{2}$ Clubmobile women did not have the luxury of morale services beyond their camaraderie, for even their leaves were populated with GIs who wanted to spend time with an American girl. Though the women did not openly challenge gender norms, clubmobile service gave them a chance to push the boundaries of acceptable female behavior by learning skills such as vehicle maintenance and by living close to the front lines, so long as their efforts could be justified as supporting the men. Explanations of the clubmobile experience on the Continent shattered traditional gender norms, even as the women's job was specifically crafted to confine their role to the support of men. As such, the veterans of the American Red Cross Clubmobile Service faced not only a civilian population who could not understand the horrors of war, but one that could not accept that a woman could have more experience of war than a man. It was not until 1982 that Marjorie Lee Morgan published her collection of clubmobilers' experiences, and

\footnotetext{
${ }^{2}$ Madison, Slinging Doughnuts for the Boys, xii.
} 
not until the late 1980s and 1990s that individual clubmobilers began publishing their memoirs. Indeed, many manuscript-length accounts of clubmobile service remain unpublished, existing solely in archives. ${ }^{3}$ This reticence reflects both society's lack of recognition of clubmobilers' wartime contributions and the women's own acceptance of their subordination to male soldiers.

The families clubmobilers formed allowed them to bear the weight of soldiers' confidences, the dangers of living in a war zone, and the societal disregard they faced, because they did so together. When Red Cross policies undermined their sisterhood, compounding officials' ignorance of their experiences, it could shatter their faith in the organization and the pride that kept them devoted to their work. Conflicts within the family had a similar effect, making daily tasks almost unbearable. However, the strength of their mutual support could not sustain the women indefinitely; eventually, the long hours and emotional strain took their toll. Life in the war zone alongside the soldiers had as profound an effect on the women as military service did on the men.

Just as contemporaries ignored clubmobilers' individuality and well-being in their concern with the men's needs, historians' focus on the lack of significant change to gender roles following the war has obscured clubmobilers' experiences, which cannot be easily compared to any category of women's wartime experience. World War II-era servicewomen were relegated to jobs that represented traditional "women's work" in order to free up male soldiers for combat; they stayed largely within the US and had little direct experience of the war. As a result, it is assumed that no woman could have witnessed firsthand the violence of the Second World War, with female war correspondents like Ruth Cowan a notable but rarely recognized exception. Nurses' wartime experiences are similarly overlooked, due to the assumption that "nursing was

\footnotetext{
${ }^{3}$ Harvard University's Collection of the American Red Cross Clubmobile Service contains six such accounts.
} 
nursing," implying that the violence and death they witnessed were a result of their profession, rather than the war environment. ${ }^{4}$

However, the experiences of clubmobile women challenge this understanding, demonstrating not only that women could and did operate as close to the front lines as many soldiers, but also that they were largely welcomed, their presence considered an important contribution to the war effort. Clubmobilers' experiences upend the prevailing understanding of midcentury gender roles, demonstrating that they were far more fluid and adaptable than most portrayals recognize. The mutability of gender roles allowed the Red Cross and the military to circumvent traditional arguments against allowing women into the war zone by framing their job as one of supporting the soldiers. Because their primary role was to boost soldiers' morale, clubmobile women were portrayed as maintaining the gendered hierarchy, giving them incredible freedom to use any means necessary to do their job. Indeed, the women were arguably most effective when they placed themselves in danger, for the surprise of seeing an American woman in a foxhole had an instant effect on a war-weary soldier. Though newly arrived soldiers might find the women's presence jarring, most men quickly came to appreciate clubmobilers' presence and often expressed their gratitude to the women for their willingness to help the soldiers and share the burden of war. However, no one recognized the significance of the women's experiences. Even clubmobilers themselves often downplayed their own experiences, acknowledging that soldiers had faced much worse.

However, despite their noncombatant status, clubmobilers lived and operated on the Continent, sometimes facing the same dangers as the men. Their experiences force us to acknowledge that it is not only "soldiers" who can or do have firsthand knowledge of war. The label "noncombatant" should not be understood as an indication of safety or lack of experience,

\footnotetext{
${ }^{4}$ Norman, "Coming to Terms with the War," 141.
} 
nor should gendered expectations of care and support obscure the importance of each individual's well-being. Occupying a support role in wartime does not preclude the individual need for support, nor does it indicate relative safety.

The prioritization of soldiers and the soldier's experience, both during the Second World War and in historical studies of war in general, ignores other firsthand experiences of conflict, not only disregarding non-soldiers' individuality and experiences, but also obscuring perspectives and accounts that could provide a more comprehensive understanding of war and how individuals experience it. Though we often expect the soldier's experience to be of combat, this is no longer the case in modern wars; one estimate suggests that in World War II, "more than 90 percent of [veterans] are as uninformed about the killing zones as those on the home front."5 However, a much larger proportion of clubmobilers found themselves witnessing the war firsthand, sometimes even thrust into combat situations. If we take the previously quoted figure, from August 1944, of 400 out of 580 clubmobilers in the ETO serving on the Continent, we can estimate that more than half of clubmobilers in the ETO served near the front lines. ${ }^{6}$ Though this represents a much smaller proportion of total Red Cross overseas workers, it is significant that, in the ETO, the label "clubmobiler" had a higher chance of indicating frontline war experience than the term "soldier."

War is not merely the realm of soldiers, and one does not have to be a soldier to experience or understand it. By prioritizing soldiers' experiences as the main narratives of war and conflict, we marginalize all others, suggesting that the experiences of clubmobilers, war correspondents, covert operatives, nurses, and civilians have less value merely because they were not officially sanctioned as combatants. By placing so much stock in simplistic, dichotomous

\footnotetext{
${ }^{5}$ William Manchester, "The Bloodiest Battle of All," New York Times Magazine, June 18, 1987, 74, quoted in Fussell, Wartime, 283.

6 "Fifty-Three Girls Arrive from the States."
} 
labels—combatant/noncombatant, soldier/civilian, masculine/feminine —we ignore individual experiences and insights, relegating them to a simple category. More complex labels like "clubmobilers" also carry certain assumptions and understandings that work to obscure individual experiences and portray a homogenous group defined solely by that specific title. Individuals do not weather the challenges and stresses of war as anonymous members of a collective, and there was a great deal of variation in the experiences of clubmobilers serving on the Continent during the final year of the war. Expanding this study to include clubmobilers serving in the UK and outside the ETO throughout the entire period of clubmobile service, from 1942 to 1946, would allow for greater understanding of the women's relationships with one another, not only in the warzone but also on training bases in the UK and in occupied Germany. This broader view would also allow for a more nuanced study of the different positions within the clubmobile department, including clubmobile dock workers like Elizabeth "Liz" Richardson, and the ways in which these subcategories affected the women's experiences and morale.

This thesis also raises broader questions about World War II morale services and the wartime experiences of women and noncombatants more generally. A comparative study including USO Camp Show Performers would allow for an examination of the stresses and challenges of overseas recreation work over different periods of time, while comparing clubmobilers' experiences with those of Red Cross club workers and USO hostesses would provide a broader understanding of wartime recreation workers. This thesis also raises questions about the morale of female recreation workers during other wars, such as the donut dollies of Korea and Vietnam, as well as the maintenance of noncombatant morale in the modern era. Indeed, it forces us to consider how militaries rely on noncombatants to achieve their wartime goals, as well as the consequences of this reliance for the noncombatants themselves. 
The experiences of American Red Cross clubmobile women serving on the Continent during World War II demonstrate what happens when a group of individuals is thrown into the environment of war with limited morale services and an overall lack of recognition that such services are necessary. Left to their own devices, these women relied on one another not only to get the job done, but also to cope with the challenges they faced. Their success or failure directly affected combat operations, yet the military and the Red Cross did little to support them or ensure their success. Paradoxically, in providing the support and individual recognition that the women needed, the clubmobile family allowed the women to be successful, further obscuring their need for official morale services.

As a subfield of history, war and society studies seek to understand how conflict affects people. It is not merely about tactics and weapons, but about understanding the lived experience of war and its short- and long-term effects on society at large. In order to do so, we cannot simply examine propaganda and societal trends; we must begin with individual stories, which we can then combine and weave together to create an overall understanding of the war. Ignoring the experiences of clubmobilers, as well as marginalizing noncombatants and women in general, leaves us with an incomplete understanding not only of World War II, but also of gender roles and wartime morale. Our understanding of clubmobilers, in turn, should be built not on numbers of donuts served and "men made happy," but on memories of shared dangers and emotional challenges, hen parties and late-night conversations. History is, in the end, about people. Though we can never truly know what it was to live in the past, we cannot gain even a limited understanding if we fail to acknowledge the agency and individuality of its inhabitants. 


\section{APPENDICES}

\section{Appendix I: Terms}

Throughout this paper, when referring to the various clubmobilers whose papers and/or publications I have drawn upon, I refer to the women by first name or nickname. I do so not only because this makes their accounts more personal, but more importantly because in many cases, their last names at the time of publication of their memoirs or donation of their papers were different from those they were known by during their Red Cross service. Simply put, the majority of clubmobile women were (re)married after their service; my sources refer to most of them by maiden names, and while I have documentation on both maiden and married names for many, I feel that using their first names and nicknames will mitigate any confusion. When introducing new women or reintroducing women in subsequent chapters, I will use their names during their Red Cross Service. ${ }^{7}$ Some women preferred to be called by their middle name; in these cases, I will place their first name in parentheses when (re)introducing them. I will also rely on nicknames to differentiate women with the same first name (I refer to two Elizabeth's, for example, each of whom favored a different nickname) and to mitigate confusion when quoted materials refer to the women by their nicknames. When multiple women were known by the same name, I will differentiate them by last initial, as it was during their Red Cross service. Clubmobilers often used the terms "girls" and "gals" to refer to themselves and one another, and they often referred to the soldiers as "boys." Contemporary readers will find the use of these terms somewhat demeaning, especially since these "girls" were around ten years older than the "boys." However, as Judy Barrett Litoff and David Smith note, "to hold women of the

\footnotetext{
${ }^{7}$ For a full list of the various women whose papers and/or publications were drawn upon for this paper, as well as their maiden and married names (when available), see Appendix III.
} 
1940s to the linguistic standards of [the present day] is both inappropriate and incorrect." ${ }^{8}$ In addition to this being the speech of the time, Julia Ramsey has argued that the Red Cross tailored the image of their "girls" to ensure that their role in the war was socially acceptable, thus providing them access to frontline soldiers. ${ }^{9}$ Historian Kara Dixon Vuic agrees that such language was a strategic choice: "Women diffused the sexual nature of their work and assured their own upright motives by affirming soldiers' inherent goodness and characterizing them as children." ${ }^{10}$ It is likely that the use of the terms "girls/gals" and "boys" was due to a combination of these factors. Not only was this the common terminology of the era, which could be used strategically to eliminate any suggestion of a sexual undertone to the job, but also, the age difference between clubmobilers and soldiers may well have made them seem like "boys."

In regards to the vehicles themselves, some sources capitalize "clubmobile," while others do not. I will not capitalize this word unless it is part of a proper name, e.g. Clubmobile Group A (as in the difference between "tank" and " $784^{\text {th }}$ Tank Battalion"). Each clubmobile also had a name, often that of a US city. All sources agree that clubmobile names are capitalized; some also place them in quotation marks or otherwise distinguish them. I have chosen to italicize clubmobile names, in the tradition of ship names (the closest comparison I could find). It is also worth noting that some clubmobiles were "rechristened" by their crews: for example, Group K's Springfield was renamed Geronimo, and the President Lincoln, of Group A, was affectionately known as $A b e^{11}$

\footnotetext{
${ }^{8}$ Judy Barrett Litoff and David C. Smith, We're in This War, Too: World War II Letters from American Women in Uniform (New York: Oxford University Press, 1994), 7.

${ }^{9}$ See Ramsey, "Girls' in Name Only."

${ }^{10}$ Vuic, The Girls Next Door, 42.

${ }^{11}$ Fay, "Through a Donut Hole," Chapter 15, and Rexford, Battlestars \& Doughnuts, 24. Group K seems to have been particularly enthusiastic in renaming their clubmobiles; according to Group Captain Elma Ernst, nearly every clubmobile in the group was rechristened. While similar observations have not been made of other groups, that is not to say that the phenomenon did not exist. Indeed, this is but one of many aspects of clubmobile life that are mentioned only in passing or by a single source but may well have been a facet of clubmobile life in general.
} 
Appendix II: The Clubmobile Groups ${ }^{12}$

\begin{tabular}{|c|c|c|c|c|}
\hline Group & Landing Date & Landing Site & Location on VE Day & Notable Events \\
\hline $\mathrm{A}$ & July 18,1944 & Utah Beach & $\begin{array}{l}\text { Section 1: Leipzig, } \\
\text { Germany } \\
\text { Section 2: Rothen, } \\
\text { Germany }\end{array}$ & \\
\hline B & $\begin{array}{l}\text { Landed July 16, } \\
\text { 1944; arrived } \\
\text { offshore July 14, } \\
1944\end{array}$ & Utah Beach & $\begin{array}{l}\text { Pilsen, } \\
\text { Czechoslovakia }\end{array}$ & $\begin{array}{l}\text { December 20, 1944: } \\
\text { Death of Katie Cullen }\end{array}$ \\
\hline $\mathrm{C}$ & July 27,1944 & Omaha Beach & Frieberg, Germany & \\
\hline $\mathrm{D}$ & July 23, 1944 & Omaha Beach & Leipzig, Germany & $\begin{array}{l}\text { September } 15,1944: \\
\text { Entered Germany } \\
\text { near Kornelimunster } \\
\text { (First Clubmobile } \\
\text { Group in Germany) }\end{array}$ \\
\hline $\mathrm{E}$ & $\begin{array}{l}\text { Landed July } 27 \text {, } \\
1944 \text { after waiting } \\
\text { in the Channel for } \\
6 \text { days }\end{array}$ & Omaha Beach & Salzwald, Germany & \\
\hline $\mathrm{F}$ & July 31,1944 & Utah Beach & Zeulenroda, Germany & $\begin{array}{l}\text { December 1944: In } \\
\text { Bastogne, Belgium } \\
\text { during the } \\
\text { Breakthrough; forced } \\
\text { to evacuate and } \\
\text { retreat into France } \\
\text { May 1, 1945: Death } \\
\text { of Jane Burdge }\end{array}$ \\
\hline $\mathrm{G}$ & August 5, 1944 & Utah Beach & $\begin{array}{l}\text { Beckum, Germany, } \\
\text { and Salzburg, Austria }\end{array}$ & \\
\hline $\mathrm{H}$ & $\begin{array}{l}\text { Landed August } \\
18,1944 \text { after } \\
\text { waiting in the } \\
\text { Channel for } 6 \\
\text { days }\end{array}$ & Utah Beach & Amberg, Germany & \\
\hline $\mathrm{K}$ & August 13, 1944 & Utah Beach & Viechtach, Germany & \\
\hline $\mathrm{L}$ & $\begin{array}{l}\text { August 17-18, } \\
1944\end{array}$ & Omaha Beach & Elangen, Germany & \\
\hline
\end{tabular}

${ }^{12}$ All information taken from Morgan, The Clubmobile, as provided by group members. 
Appendix III: Clubmobilers Referenced in this Paper (By Group) ${ }^{13}$

\begin{tabular}{|c|c|c|c|c|c|c|}
\hline Full Name & $\begin{array}{l}\text { Name used } \\
\text { by fellow } \\
\text { clubmobilers }\end{array}$ & Group & $\begin{array}{l}\text { Beginning } \\
\text { of ARC } \\
\text { service (if } \\
\text { available) }\end{array}$ & $\begin{array}{l}\text { Returned } \\
\text { to US (if } \\
\text { available) }\end{array}$ & $\begin{array}{l}\text { Friends } \\
\text { mentioned } \\
\text { in this } \\
\text { paper }\end{array}$ & Notes \\
\hline $\begin{array}{l}\text { Rosemary } \\
\text { "Rosie" } \\
\text { Langheldt } \\
\text { Norwalk }\end{array}$ & $\begin{array}{l}\text { Rosie } \\
\text { Langheldt }\end{array}$ & $\begin{array}{l}\text { N/A -- dock } \\
\text { operations in } \\
\text { Southampton }\end{array}$ & $\begin{array}{l}\text { Joined } \\
\text { May 1944; } \\
\text { arrived in } \\
\text { Britain } \\
\text { July } 1944\end{array}$ & April 1946 & $\begin{array}{l}\text { Margaret } \\
\text { "Bettie" } \\
\text { Gearhart } \\
\text { Brodie* }\end{array}$ & $\begin{array}{l}\text { In charge of } \\
\text { clubmobile } \\
\text { operations in } \\
\text { the } \\
\text { Southampton } \\
\text { area }\end{array}$ \\
\hline $\begin{array}{l}\text { Virginia } \\
\text { "Ginny" } \\
\text { Billingsley } \\
\text { Guerriero }\end{array}$ & $\begin{array}{l}\text { Ginny } \\
\text { Billingsley }\end{array}$ & $\begin{array}{l}\text { N/A -- dock } \\
\text { operations in } \\
\text { Scotland }\end{array}$ & & & & \\
\hline $\begin{array}{l}\text { Elizabeth "Liz" } \\
\text { Richardson }\end{array}$ & $\begin{array}{l}\text { Liz } \\
\text { Richardson }\end{array}$ & $\begin{array}{l}\text { N/A - dock } \\
\text { operations in } \\
\text { Le Havre }\end{array}$ & $\begin{array}{l}\text { Joined } \\
\text { March } \\
1944 ; \\
\text { arrived in } \\
\text { Britain } \\
\text { July } 1944\end{array}$ & N/A & & $\begin{array}{l}\text { Died July 25, } \\
1945\end{array}$ \\
\hline $\begin{array}{l}\text { Constance } \\
\text { "Connie" } \\
\text { Fagan Russe }\end{array}$ & Connie Fagan & $\begin{array}{l}\text { N/A -dock } \\
\text { operations in } \\
\text { Marseille/ } \\
\text { Omaha } \\
\text { District }\end{array}$ & $\begin{array}{l}\text { Arrived in } \\
\text { Britain } \\
\text { May } 1944\end{array}$ & $\begin{array}{l}\text { October } \\
1945\end{array}$ & & \\
\hline $\begin{array}{l}\text { Virginia } \\
\text { Wilson Cook } \\
\text { Osgood }\end{array}$ & Virginia Cook & $\begin{array}{l}\text { N/A - } \\
\text { Assistant } \\
\text { Director of } \\
\text { Personnel }\end{array}$ & $\begin{array}{l}\text { Arrived in } \\
\text { Britain } \\
\text { August } \\
1943\end{array}$ & & & $\begin{array}{l}\text { Joined } \\
\text { Personnel } \\
\text { Dept. July } \\
\text { 1944; } \\
\text { Assistant } \\
\text { Personnel } \\
\text { Director } \\
\text { December } \\
1944\end{array}$ \\
\hline $\begin{array}{l}\text { Anne Ferguson } \\
\text { Boy }\end{array}$ & $\begin{array}{l}\text { Anne } \\
\text { Ferguson }\end{array}$ & A & $\begin{array}{l}\text { Joined } \\
\text { July 1943; } \\
\text { arrived in }\end{array}$ & $\begin{array}{l}\text { August } \\
1945\end{array}$ & $\begin{array}{l}\text { Mary } \\
\text { Pitcairn, } \\
\text { Jane Weir }\end{array}$ & $\begin{array}{l}\text { Section } \\
\text { Captain late } \\
1944 ;\end{array}$ \\
\hline
\end{tabular}

\footnotetext{
${ }^{13}$ The women included in this table are those whose papers/publications were available to me, as well as those who were killed during their service. Women mentioned in accounts taken from The Clubmobile are not included, though I have done my best to include their full names in (the footnotes of) the main body of the paper. While I have no specific reference to any women of Group $\mathrm{C}$, and have no access to papers or personal information for anyone in Group B, general information on the activities of each group is available in Morgan, The Clubmobile.
} 


\begin{tabular}{|c|c|c|c|c|c|c|}
\hline & & & $\begin{array}{l}\text { Britain } \\
\text { October } \\
1943\end{array}$ & & $\begin{array}{l}\text { Phillips } \\
\text { Scott*, } \\
\text { Harriette } \\
\text { "Viki" } \\
\text { Atkinson } \\
\text { (Group } \\
\text { Captain) }\end{array}$ & $\begin{array}{l}\text { married July } \\
1945\end{array}$ \\
\hline $\begin{array}{l}\text { Eleanor } \\
\text { "Dugal" } \\
\text { Campbell } \\
\text { Walker } \\
\text { Schroeder }\end{array}$ & $\begin{array}{l}\text { Dugal } \\
\text { Campbell }\end{array}$ & A & $\begin{array}{l}\text { Arrived in } \\
\text { Britain } \\
\text { July } 1944\end{array}$ & & & \\
\hline $\begin{array}{l}\text { Jane Weir } \\
\text { Phillips Scott }\end{array}$ & Jane Phillips & A & $\begin{array}{l}\text { Arrived in } \\
\text { Britain } \\
\text { January } \\
1944\end{array}$ & July 1945 & $\begin{array}{l}\text { Anne } \\
\text { Ferguson } \\
\text { Boy*, Mary } \\
\text { Pitcairn }\end{array}$ & \\
\hline $\begin{array}{l}\text { Jean } \\
\text { Hemingway } \\
\text { Hackleman }\end{array}$ & $\begin{array}{l}\text { Jean } \\
\text { Hemingway }\end{array}$ & A & $\begin{array}{l}\text { Joined } \\
\text { March } \\
1944 ; \\
\text { arrived in } \\
\text { Britain } \\
\text { June 1944 }\end{array}$ & $\begin{array}{l}\text { December } \\
1945\end{array}$ & & $\begin{array}{l}\text { Married } \\
\text { November } \\
1945\end{array}$ \\
\hline $\begin{array}{l}\text { Mary "Chichi" } \\
\text { Marshall } \\
\text { Metcalfe } \\
\text { Rexford }\end{array}$ & $\begin{array}{l}\text { Chichi } \\
\text { Metcalfe }\end{array}$ & A & $\begin{array}{l}\text { Joined } \\
\text { August } \\
1943 ; \\
\text { arrived in } \\
\text { Britain } \\
\text { January } \\
1944\end{array}$ & $\begin{array}{l}\text { October } \\
1945\end{array}$ & & \\
\hline $\begin{array}{l}\text { Ann Kathleen } \\
\text { "Katie" Cullen }\end{array}$ & Katie Cullen & B & $\begin{array}{l}\text { Joined } \\
\text { June } 1943\end{array}$ & N/A & & $\begin{array}{l}\text { Died } \\
\text { December } \\
20,1944\end{array}$ \\
\hline $\begin{array}{l}\text { Nancy Bastien } \\
\text { Chase*** }\end{array}$ & Nancy Bastien & D & $\begin{array}{l}\text { Arrived in } \\
\text { Britain } \\
\text { May } 1944\end{array}$ & & & \\
\hline $\begin{array}{l}\text { Jane Anne } \\
\text { McKee Jack }\end{array}$ & Anne Jack & $\mathrm{E}$ & $\begin{array}{l}\text { Joined late } \\
1942\end{array}$ & July 1945 & $\begin{array}{l}\text { Helen } \\
\text { "Mac" } \\
\text { McGregor, } \\
\text { Virginia } \\
\text { "Ginny" } \\
\text { Weisbrod**, } \\
\text { Elizabeth } \\
\text { "Betty" } \\
\text { Schuller }\end{array}$ & $\begin{array}{l}\text { Worked at } \\
\text { Red Cross } \\
\text { Headquarters } \\
\text { in the UK } \\
\text { until March } \\
\text { 1943; crew } \\
\text { captain }\end{array}$ \\
\hline
\end{tabular}




\begin{tabular}{|c|c|c|c|c|c|c|}
\hline & & & & & $\begin{array}{l}\text { (Group } \\
\text { Captain) }\end{array}$ & \\
\hline $\begin{array}{l}\text { Gretchen } \\
\text { Schuyler }\end{array}$ & $\begin{array}{l}\text { Gretchen } \\
\text { Schuyler }\end{array}$ & $\mathrm{F}$ & $\begin{array}{l}\text { Arrived in } \\
\text { Britain } \\
\text { May } 1943\end{array}$ & July 1945 & $\begin{array}{l}\text { Bonnie } \\
\text { O’Brien, } \\
\text { Maxine } \\
\text { Preas, Helen } \\
\text { Stockdale }\end{array}$ & Group \\
\hline $\begin{array}{l}\text { Dorothy Jane } \\
\text { Burdge }\end{array}$ & Jane Burdge & $\mathrm{F}$ & & N/A & & $\begin{array}{l}\text { Died May 1, } \\
1945\end{array}$ \\
\hline $\begin{array}{l}\text { Jill Pitts } \\
\text { Knappenberger }\end{array}$ & Jill Pitts & F & $\begin{array}{l}\text { Arrived in } \\
\text { Britain } \\
\text { January } \\
1944\end{array}$ & $\begin{array}{l}\text { August } \\
1945\end{array}$ & & \\
\hline $\begin{array}{l}\text { Elizabeth } \\
\text { "Bettie" } \\
\text { Walters } \\
\text { MacInnes }\end{array}$ & Bettie Walters & G & $\begin{array}{l}\text { Joined } \\
\text { July 1943; } \\
\text { arrived in } \\
\text { Britain } \\
\text { October } \\
1943\end{array}$ & $\begin{array}{l} \\
\text { August/ } \\
\text { September } \\
1945\end{array}$ & $\begin{array}{l}\text { Henrietta } \\
\text { Barker } \\
\text { (Kyle) }\end{array}$ & $\begin{array}{l}\text { Cinemobile } \\
\text { operator; } \\
\text { transferred to } \\
\text { clubmobiles } \\
\text { December } \\
1944\end{array}$ \\
\hline $\begin{array}{l}\text { Eva Maria } \\
\text { Christensen } \\
\text { Johnson }\end{array}$ & $\begin{array}{l}\text { Eva } \\
\text { Christensen }\end{array}$ & $\mathrm{H}$ & $\begin{array}{l}\text { Joined } \\
\text { November } \\
1942 ; \\
\text { arrived in } \\
\text { Britain } \\
\text { January } \\
1943\end{array}$ & $\begin{array}{l} \\
\text { September } \\
1945\end{array}$ & & $\begin{array}{l}\text { Group } \\
\text { Captain }\end{array}$ \\
\hline Portia Miller & Portia Miller & $\mathrm{H}$ & & N/A & & $\begin{array}{l}\text { Died August } \\
1945\end{array}$ \\
\hline $\begin{array}{l}\text { Harriet } \\
\text { Engelhardt }\end{array}$ & $\begin{array}{l}\text { Harriet } \\
\text { Engelhardt }\end{array}$ & $\mathrm{H}$ & & N/A & & $\begin{array}{l}\text { Died October } \\
26,1945\end{array}$ \\
\hline $\begin{array}{l}\text { Angela } \\
\text { "Angie" } \\
\text { Petesch }\end{array}$ & Angie Petesch & $\mathrm{H}$ & $\begin{array}{l}\text { Arrived in } \\
\text { Britain } \\
\text { May } 1943\end{array}$ & $\begin{array}{l}\text { September } \\
1945\end{array}$ & & $\begin{array}{l}\text { Section } \\
\text { Captain late } \\
\text { November } \\
1944\end{array}$ \\
\hline $\begin{array}{l}\text { Betty Jane } \\
\text { "B.J" Thomas } \\
\text { Olewiler** }\end{array}$ & B.J. Thomas & $\mathrm{H}$ & $\begin{array}{l}\text { Arrived in } \\
\text { Britain } \\
\text { January } \\
1944\end{array}$ & $\begin{array}{l}\text { October } \\
1945\end{array}$ & & \\
\hline $\begin{array}{l}\text { Mary Louise } \\
\text { "Mary Lou" } \\
\text { Pearce Hart }\end{array}$ & $\begin{array}{l}\text { Mary Lou } \\
\text { Pearce }\end{array}$ & $\mathrm{H}$ & $\begin{array}{l}\text { Arrived in } \\
\text { Britain } \\
\text { April } 1944\end{array}$ & $\begin{array}{l}\text { September } \\
+1945\end{array}$ & & \\
\hline $\begin{array}{l}\text { Patricia } \\
\text { Maddox }\end{array}$ & $\begin{array}{l}\text { Patricia } \\
\text { Maddox }\end{array}$ & $\mathrm{H}$ & & & & \\
\hline
\end{tabular}




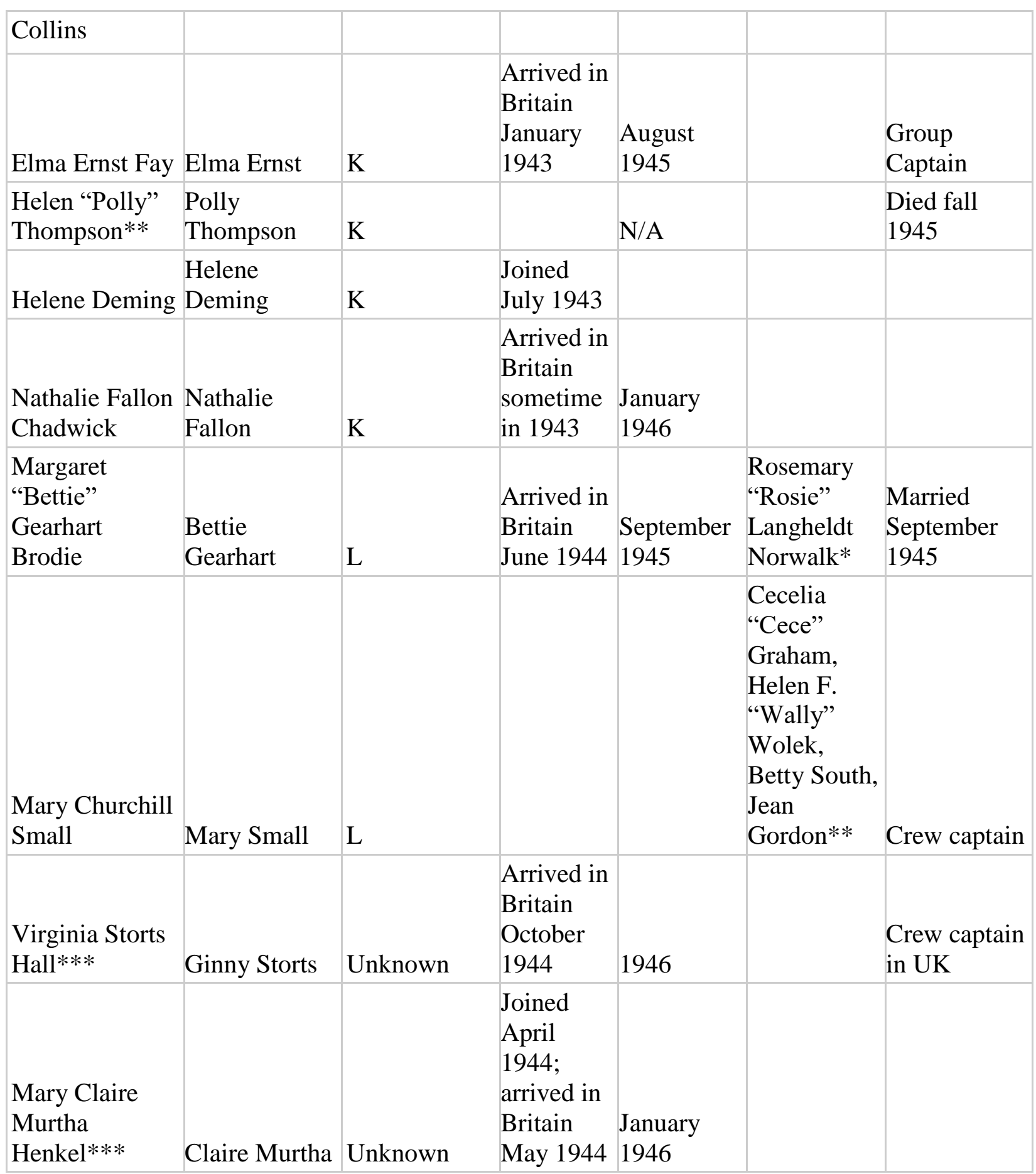

*Women who appear elsewhere in this table.

**Women whose full name is not specified by the original source and is based on the group rosters available in The Clubmobile and/or other documentation, including obituaries.

***While I do not refer to these women by name, their papers included official documents and other papers that I reference. 


\section{BIBLIOGRAPHY}

\section{Primary Sources}

Archival Collections:

Collection of the American Red Cross Clubmobile Service, 1940-1998 (inclusive), 1943-1946 (bulk), MC 550. Schlesinger Library, Harvard University, Cambridge, MA.

Papers of Gretchen Schuyler, 1917-2002, 2005-m150-2006-m174. Schlesinger Library, Harvard University, Cambridge, MA.

Papers of Mary Churchill Small, 1943-1947, 2010-m129. Schlesinger Library, Harvard University, Cambridge, MA.

Walters Family Second World War Correspondence, 2017-308-w-r. Center for American War Letters, Chapman University, Orange, CA.

Published Accounts of/by Clubmobilers:

Johnson, Eva Maria. I Too Shall Wear Purple. New York: Carlton Press, 1987.

Madison, James H. Slinging Doughnuts for the Boys: An American Woman in World War II. Bloomington, IN: Indiana University Press, 2007.

Morgan, Marjorie Lee, ed. The Clubmobile-The ARC in the Storm: A Personal History Of and By The Clubmobilers In The European Theater of War During World War II. St. Petersburg, FL: Hazlett, 1982.

Norwalk, Rosemary. Dearest Ones: A True World War II Love Story. New York: John Wiley \& Sons, Inc., 1999.

Olewiler, B.J. A Woman in a Man's War. Xlibris, 2003.

Petesch, Angela. War Through the Hole of a Donut. Madison, WI: Hunter Halverson Press, 2006.

Rexford, Oscar Whitelaw, ed. Battlestars \& Doughnuts: World War II Clubmobile Experiences of Mary Metcalfe Rexford. St. Louis: The Patrice Press, 1989.

\section{Clubmobile Newspaper:}

Brooks, J. Clarice. “Aboard the Massachusetts.” Sinker, Dec. 9, 1943.

“Chow Hounds Par Excellence.” Sinker, Apr. 6, 1945. 
“Christmas Card Contest Announced." Sinker, Sept. 29, 1943.

“Clubmobilers Spend Busy, Memorable Christmas.” Sinker, Jan. 6, 1944.

“C.O.F.F.E.E....G.R.O.U.N.D.S.” Sinker, Feb. 2, 1945.

"Everyone Who is in Red Cross Work Over Here." Sinker, Dec. 8, 1944.

"Fifty-Three Girls Arrive from the States." Sinker, Aug. 4, 1944.

“The GIs.” Sinker, Sept. 15, 1944.

"How to Make Doughnuts (?)." Sinker, Nov. 10, 1944.

“HQ Communiques.” Sinker, Sept. 1, 1944.

King, Eliza. “A Doughgirl's Life.” Sinker, Sept. 29, 1943.

_. "Variations on a Theme in C \& D." Sinker, Feb. 2, 1944.

Mitchell, S. Keene, Jr. “Christmas Greeting from Mr. Mitchell.” Sinker, Dec. 23, 1944.

"Presentation Dinner for Mr. Momand." Sinker, June 23, 1944.

"Read it and Weep." Sinker, Sept. 29, 1943.

“The Sinker Makes its Bow.” Sinker, Aug. 15, 1943.

“Zone V Plans.” Sinker, June 9, 1944.

Other:

American National Red Cross. Red cross service record: accomplishments of seven years: July 1, 1939-June 30, 1946. Washington, D.C.: Office of Program Research, The American National Red Cross, 1946.

https://babel.hathitrust.org/cgi/pt?id=uiug.30112072374926;view=1up;seq=48.

- Services to the Armed Forces. Washington, D.C.: The American National Red Cross, 1942. https://babel.hathitrust.org/cgi/pt?id=uiug.30112076215893; view=1 up;seq=33.

Army Life. Washington, D.C.: United States Government Printing Office, 1944. https://babel.hathitrust.org/cgi/pt?id=mdp.39015042999048; view=1up;seq=53.

“Celebrating the Heroic Women of World War II's Clubmobile Service.” Accessed July 9, 2020. clubmobile.org. 
“Dr. Betty Jane 'B.J.' Olewiler Ph.D.” York Daily Record (York County, PA), Sept. 15, 2005. https://www.legacy.com/obituaries/york/obituary.aspx?n=betty-jane-olewilerbj\&pid=15091994.

Durant, Henry. "Morale and Its Measurement." American Journal of Sociology 47, no. 3 (Nov. 1941): 406-14. www.jstor.org/stable/2769290.

Guerard, Albert. "Toward American Morale." The Virginia Quarterly Review 18, no. 1 (Winter 1942): 1-12. www.jstor.org/stable/26456868.

“Join Us.” American Red Cross Overseas Association. Accessed August 12, 2019. https://www.arcoa.org/join-us.

Kelly, Lora. "Red Cross Clubmobiles Abroad." The Red Cross Courier 27, no. 10 (April 1943): 11, 18. https://babel.hathitrust.org/cgi/pt?id=umn.31951002790942e;view=1up;seq=693.

Korson, George Gershon. At His Side: The Story of the American Red Cross Overseas In World War II. New York: Coward-McCann, Inc, 1945. https://babel.hathitrust.org/cgi/pt?id=mdp.39015031930426\&view=1up\&seq=284.

Kotcher, Joann Puffer. Donut Dolly: An American Red Cross Girl's War in Vietnam. Denton, TX: University of North Texas Press, 2011.

Lindeman, Eduard C. "Recreation and Morale." American Journal of Sociology 47, no. 3 (Nov. 1941): 394-405. https://www.jstor.org/stable/2769289.

Rose, Arnold. "Bases of American Military Morale in World War II." The Public Opinion Quarterly 9, no. 4 (Winter 1945-1946): 411-17. https://www.jstor.org/stable/2745554.

United States Army. Report of Operations (Final After Action Report): 12th Army Group. Vol. 2. 1945. https://babel.hathitrust.org/cgi/pt?id=mdp.39015051394743\&view=1up\&seq=26.

\section{Secondary Sources}

“All's Fair in Love and War - 11 Famous Military Leaders Who Kept Mistresses.” Military History Now. Last modified June 17, 2016. https://militaryhistorynow.com/2016/06/17/womanizing-warriors-11-famous-militaryleaders-who-kept-mistresses/.

Beals, Adison. "The Anatomy of Patriotism: The Commodification of American Gender Roles and the Female Body in World War II Print Media." Voces Novae 11 (2019). https://digitalcommons.chapman.edu/vocesnovae/vol11/iss1/1.

Bierman, Alex, and Ryan Kelty. "The Threat of War and Psychological Distress Among Civilians Working in Iraq and Afghanistan.” Social Psychology Quarterly 77, no. 1 (March 2014): 27-53. http://www.jstor.com/stable/43186713. 
Brailey, Kevin, Jennifer J. Vasterling, Susan P. Proctor, Joseph I. Constans, and Matthew J. Friedman. "PTSD Symptoms, Life Events, and Unit Cohesion in U.S. Soldiers: Baseline Findings from the Neurocognition Deployment Health Study." Journal of Traumatic Stress 20, no. 4 (August 2007): 495-503. https://search-ebscohost-

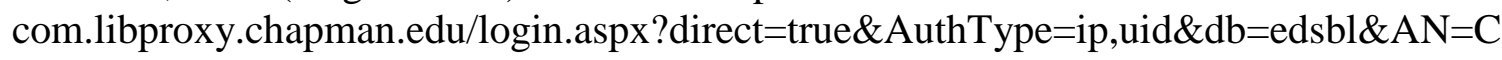
N065850009\&site $=$ eds-live.

Brown, Theodore M. "'Stress' in US Wartime Psychiatry: World War II and the Immediate Aftermath." In Stress, Shock, and Adaptation in the Twentieth Century, edited by David Cantor and Edmund Ramsden, 121-41. Rochester: University of Rochester Press, 2014. http://www.jstor.com/stable/10.7722/j.ctt4cg6bs.9.

Campbell, D’Ann. "Women in Combat: The World War II Experience in the United States, Great Britain, Germany, and the Soviet Union." The Journal of Military History 57, no. 2 (Apr. 1993): 301-23. https://www.jstor.org/stable/2944060.

Carter Olson, Candi S. “"This Was No Place for a Woman': Gender Judo, Gender Stereotypes, and World War II Correspondent Ruth Cowan." American Journalism 34, no. 4 (2017): 427-47.

http://eds.a.ebscohost.com.libproxy.chapman.edu/eds/pdfviewer/pdfviewer?vid=1\&sid=c a5593e6-3797-4299-9ecc-9ae5b4111eaf\%40sessionmgr4007.

Childers, Thomas. Soldier from the War Returning: The Greatest Generation's Troubled Homecoming from World War II. Boston: Houghton Mifflin Harcourt, 2009.

Cooke, James J. American Girls, Beer, and Glenn Miller: GI Morale in World War II. The American Military Experience Series. Columbia, MO: University of Missouri Press, 2012. https://search-ebscohost-

com.libproxy.chapman.edu/login.aspx?direct=true $\&$ AuthType $=$ ip, $u i d \& d b=$ nlebk $\& A N=5$ 02659\&site=eds-live.

Crepeau-Hobson, Franci, and Linda M. Kanan. "After the Tragedy: Caring for the Caregivers." The Phi Delta Kappan 95, no. 4 (Dec. 2013/Jan. 2014): 33-7. www.jstor.org/stable/23611833.

"Dachau Concentration Camp, 1933-1945." KZ-Gedenkstätte Dachau. Stiftung Bayerische Gedenkstätten. Accessed April 28, 2020. https://www.kz-gedenkstaettedachau.de/en/historical-site/dachau-concentration-camp-1933-1945/.

"Dora-Mittelbau: Overview." Holocaust Encyclopedia, United States Holocaust Memorial Museum. Accessed August 22, 2019. https://encyclopedia.ushmm.org/content/en/article/dora-mittelbau-overview.

Duncombe, Stephen. “Cultural Hegemony.” In Beautiful Trouble: A Toolbox for Revolution, edited by Andrew Boyd and Dave Oswald Mitchell, 222-5. New York; London: OR Books, 2012. www.jstor.org/stable/j.ctt1bkm5nd.94. 
Fischer, Lucy. "Girl Groups: Female Friendship." In Shot/Countershot: Film Tradition and Women's Cinema, 216-49. Princeton: Princeton University Press, 1989. http://www.jstor.com/stable/j.ctt7zv9rz.11.

Fussell, Paul. The Great War and Modern Memory. London: Oxford University Press, 1975.

- Wartime: Understanding and Behavior in the Second World War. New York: Oxford University Press, 1989.

Goldin, Claudia, and Claudia Olivetti. "Shocking Labor Supply: A Reassessment of the Role of World War II on Women's Labor Supply." American Economic Review: Papers \& Proceedings 103, no. 3 (2013): 257-62. https://search-ebscohostcom.libproxy.chapman.edu/login.aspx?direct=true \&AuthType=ip,uid\&db=edsjsr\&AN=e dsjsr.23469739\&site=eds-live.

Griffith, James. "Measurement of Group Cohesion in U.S. Army Units." Basic and Applied Social Psychology 9, no. 2 (1988): 149-71. doi:10.1207/s15324834basp0902_6.

Hagen, Claudia. American Women During World War II. CreateSpace Independent Publishing Platform, 2015.

Hanna, Martha. "War Letters: Communication between Front and Home Front." 1914-1918 Online: International Encyclopedia of the First World War. Last modified October 8, 2014. https://encyclopedia.1914-1918online.net/article/war_letters_communication_between_front_and_home_front.

Harrington, Sara. "Women's Work: Domestic Labor in American World War II Posters." Art Documentation 22, no. 2 (2003): 41-4.

http://eds.b.ebscohost.com.libproxy.chapman.edu/eds/pdfviewer/pdfviewer?vid=3\&sid=1 579069c-43b7-4e39-ba9b-1f94663ec049\%40pdc-v-sessmgr03.

Henkin, David M. "Precious as Gold: Mobility and Family in the Gold Rush and Civil War." In The Postal Age: The Emergence of Modern Communications in Nineteenth-Century America, 119-47. Chicago: University of Chicago Press, 2007.

"Henri-Chapelle American Cemetery." American Battle Monuments Commission. Accessed April 28, 2020. https://www.abmc.gov/database-search.

Honey, Maureen. "The 'Womanpower' Campaign: Advertising and Recruitment Propaganda during World War II." Frontiers: A Journal of Women Studies 6, no. 1/2 (Spring-Summer 1981): 50-6. https://www.jstor.org/stable/3346491.

—. "The Working-Class Woman and Recruitment Propaganda during World War II: Class Differences in the Portrayal of War Work." Signs 8, no. 4 (Summer 1983): 672-87. https://www.jstor.org/stable/3173689.

Kindsvatter, Peter S. American Soldiers: Ground Combat in the World Wars, Korea, \& Vietnam. Lawrence, KS: University Press of Kansas, 2003. 
Kopko, Kyle C., E. Fletcher McClellan, Christopher J. Devine, Jillian E. Casey, and Julia L. Ward. "The Politics of the Presidential Medal of Freedom: A Fifty Year Analysis, 19632013." New England Journal of Political Science 8, no. 2 (2015): 156-84.

https://ecommons.udayton.edu/cgi/viewcontent.cgi?article=1081\&context=pol_fac_pub.

Lair, Meredith. Armed with Abundance: Consumerism and Soldiering in the Vietnam War. Chapel Hill: University of North Carolina Press, 2014.

Lambright, Jeanie Sutton. They Also Served: Women's Stories from the World War II Era. Xlibris, 2003.

"Liberation of Dora-Mittelbau." Timeline of Events, United States Holocaust Memorial Museum. Accessed August 22, 2019. https://www.ushmm.org/learn/timeline-of-events/19421945/liberation-of-dora-mittelbau.

Litoff, Judy Barrett, and David C. Smith. “'Will He Get My Letter?': Popular Portrayals of Mail and Morale During World War II." Journal of Popular Culture 23, no. 4 (Spring 1990): 21-43.

- We're in This War, Too: World War II Letters from American Women in Uniform. New York: Oxford University Press, 1994.

Martínez Alemán, Ana M. “College Women's Female Friendships: A Longitudinal View." The Journal of Higher Education 81, no. 5 (September/October 2010): 553-82. http://www.jstor.com/stable/40835719.

McEuen, Melissa A. Making War, Making Women: Femininity and Duty on the American Home Front, 1941-1945. Athens, GA: University of Georgia Press, 2010. https://searchebscohostcom.libproxy.chapman.edu/login.aspx?direct=true \&AuthType=ip,uid\&db=nlebk\&AN=3 $75875 \&$ site $=$ eds-live.

Merryman, Molly. "Recognizing the Gendered Warrior: History and Theory Intersect with the Fate of the WASPs." In Clipped Wings: The Rise and Fall of the Women Airforce Service Pilots (WASPS) of World War II, 157-81. New York: NYU Press, 1998. https://www.jstor.org/stable/j.ctt9qgb65.14.

Meyer, Leisa D. Creating G.I. Jane: Sexuality and Power in the Women's Army Corps During World War II. New York: Columbia University Press, 1998.

Introduction to Mollie's War: The Letters of a World War II WAC in Europe, 3-9. Mollie Weinstein Schaffer and Cyndee Schaffer. Jefferson, NC: McFarland \& Company, Inc., 2010.

Michel, Sonya. "American Women and the Discourse of the Democratic Family in World War II." In Behind the Lines: Gender and the Two World Wars, edited by Margaret Randolph Higonnet, Jane Jenson, Sonya Michel, and Margaret Collins Weitz, 154-67. New Haven, CT: Yale University Press: 1987. https://www.jstor.org/stable/j.ctt1cc2m97.15. 
. "Danger on the Home Front: Motherhood, Sexuality, and Disabled Veterans in American Postwar Films." Journal of the History of Sexuality 3, no. 1 (Jul. 1992): 109-28. http://www.jstor.com/stable/3704374.

Murray, Melissa. "Made with Men in Mind: The GI Bill and Its Reinforcement of Gendered Work after World War II." In Feminist Legal History: Essays on Women and Law, edited by Tracy A. Thomas and Tracey Jean Boisseau, 84-99. New York: NYU Press, 2011. https://www.jstor.org/stable/j.ctt15zc8jt.9.

Norman, Elizabeth M. "Coming to Terms with the War: Post-Traumatic Stress Disorder." In Women at War: The Story of Fifty Military Nurses Who Served in Vietnam, 141-54. Philadelphia: University of Pennsylvania Press, 1990. http://www.jstor.com/stable/j.ctt3fhsqj.17.

Oliver, Laurel W., Joan Harman, Elizabeth Hoover, Stephanie M. Hayes, and Nancy A. Pandhi. "A Quantitative Integration of the Military Cohesion Literature." Military Psychology 11, no. 1 (1999): 57-83. doi:10.1207/s15327876mp1101_4.

Peterson, Andrea. "Shell-shocked in Somerville: Vera Brittain's post-traumatic stress disorder." In Gender and warfare in the twentieth century: Textual representations, edited by Angela K. Smith, 33-52. Manchester: Manchester University Press, 2004. http://www.jstor.com/stable/j.ctt2121689.7.

Pirnie, Bruce R., Major. "Division and Corps Command Posts in World War II." Unclassified report. Washington, D.C.: U.S. Army Center of Military History, 1986. https://apps.dtic.mil/dtic/tr/fulltext/u2/a167405.pdf.

Pols, Hans. "War Neurosis, Adjustment Problems in Veterans, and an Ill Nation: The Disciplinary Project of American Psychiatry during and after World War II." Osiris 22, no. 1 (2007): 72-92. https://www.jstor.org/stable/10.1086/521743.

Ramsey, Julia A. "'Girls' in Name Only: A Study of American Red Cross Volunteers on the Frontlines of World War II.” Master's Thesis, Auburn University, 2011. https://etd.auburn.edu/bitstream/handle/10415/2616/ramsey_julia_ma_thesis_history_pos t_defense_and_AUETD_check_5.9.11.pdf;sequence=3.

"Search ABMC Burials and Memorials." American Battle Monuments Commission. Accessed April 28, 2020. https://www.abmc.gov/database-search.

Sinnott, Susan. Doing Our Part: American Women on the Home Front during World War II. New York: F. Watts, 1995.

Strachan, Hew. "Training, Morale and Modern War." Journal of Contemporary History 41, no. 2 (Apr. 2006): 211-27. http://www.jstor.com/stable/30036383.

Threat, Charissa. "Patriotism is Neither Masculine nor Feminine': Gender and the Work of War." In The Routledge History of Gender, War, and the U.S. Military, edited by Kara Dixon Vuic, 233-46. New York: Routledge, 2018. 
“United States presidential election of 1944." Encyclopadia Britannica. Last modified October 31, 2019. https://www.britannica.com/event/United-States-presidential-election-of-1944.

Vaitkus, Mark, and James Griffith. "An Evaluation of Unit Replacement on Unit Cohesion and Individual Morale in the U.S. Army All-Volunteer Force." Military Psychology 2, no. 4 (1990): 221-39. doi:10.1207/s15327876mp0204_3.

Vuic, Kara Dixon. The Girls Next Door: Bringing the Home Front to the Front Lines. Cambridge, MA: Harvard University Press, 2019.

Weatherford, Doris. American Women and World War II. Edison, NJ: Castle Books, 2008. American Women during World War II: An Encyclopedia. New York: Routledge, 2010.

Webster, Ian. "Value of \$1 from 1945 to 2020." CPI Inflation Calculator. Accessed June 26, 2020. https://www.in2013dollars.com/us/inflation/1945?amount=1.

Westbrook, Robert B. “'I Want a Girl, Just Like the Girl that Married Harry James': American Women and the Problem of Political Obligation in World War II." American Quarterly 42, no. 4 (Dec. 1990): 587-614. https://www.jstor.org/stable/2713166.

Whitesell, Allison A., and Gina P. Owens. "The Impact of Patriotism, Morale, and Unit Cohesion on Mental Health in Veterans of Iraq and Afghanistan." Traumatology 18, no. 1 (2012): 1-7. doi:10.1177/1534765610395625.

Winchell, Meghan K. Good Girls, Good Food, Good Fun: The Story of USO Hostesses during World War II. Chapel Hill: University of North Carolina Press, 2015. http://libproxy.chapman.edu/login?url=https://search.ebscohost.com/login.aspx?direct=tr ue $\&$ AuthType $=$ ip, uid $\& \mathrm{db}=$ nlebk $\& A N=275333 \&$ site $=$ edslive\&ebv=EB\&ppid=pp_Cover.

Yellin, Emily. Our Mothers' War: American Women at Home and at the Front During World War II. New York: Free Press, 2004.

Zentner, John J. "The Morale Problem." In The Art of Wing Leadership: Zentner and Aircrew Morale in Combat, 11-22. Air University Press: 2001. https://www.jstor.org/stable/resrep13783.8. 